\title{
Chemical Tools for Studying Lipid-Binding Class A G Protein-Coupled Receptors
}

\author{
Anna Cooper, Sameek Singh, Sarah Hook, Joel D. A. Tyndall, and Andrea J. Vernall \\ School of Pharmacy, University of Otago, Dunedin, New Zealand
}

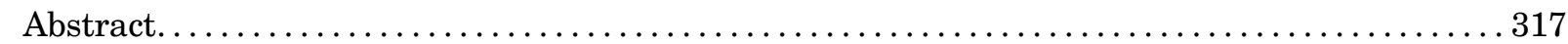

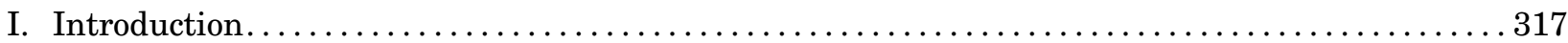

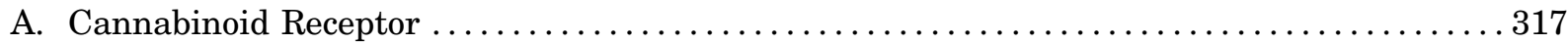

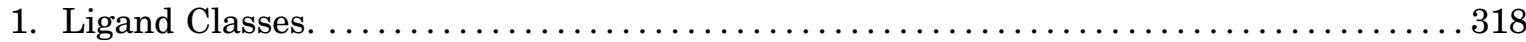

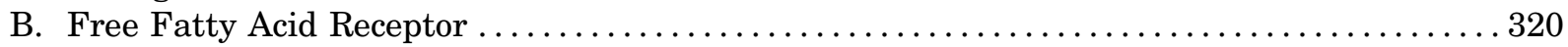

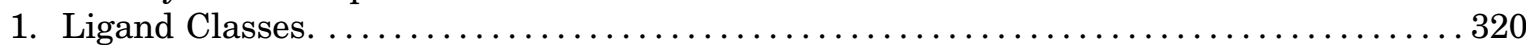

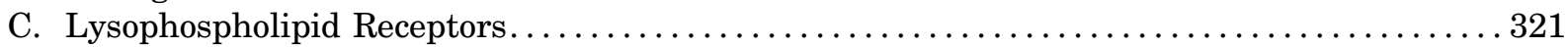

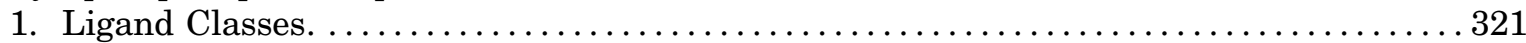

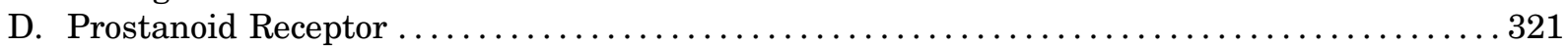

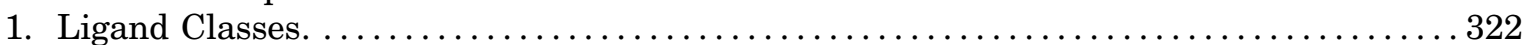

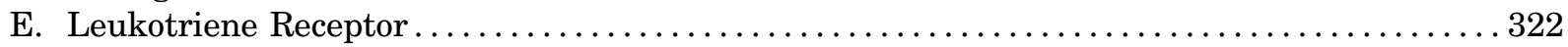

1. Ligand Classes. .................................................. 322

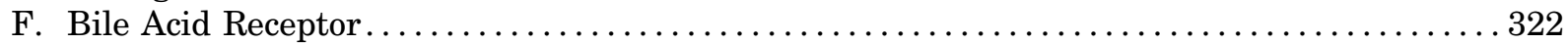

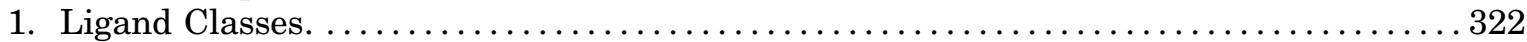

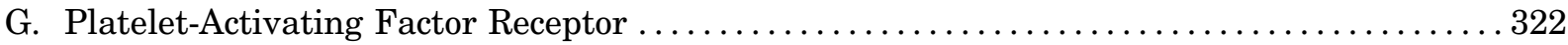

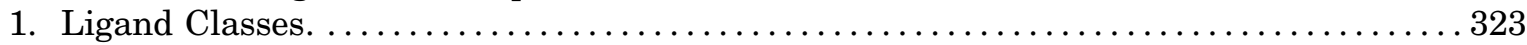

H. Orphan G Protein-Coupled Receptors .................................... 323

I. Rational Design of Tools and Considerations for Use $\ldots \ldots \ldots \ldots \ldots \ldots \ldots \ldots \ldots \ldots \ldots \ldots \ldots$

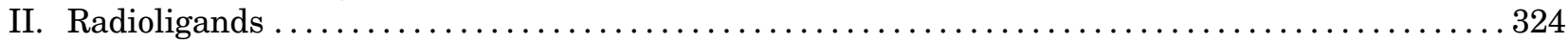

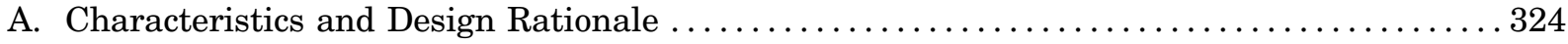

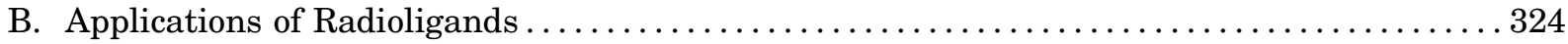

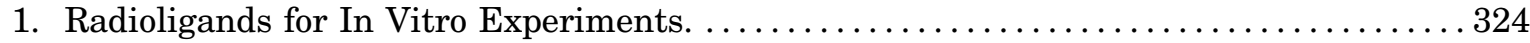

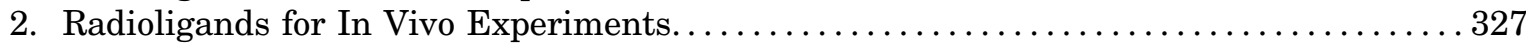

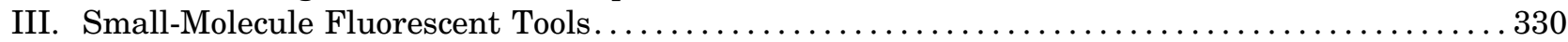

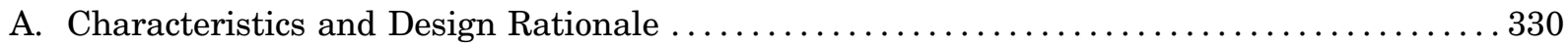

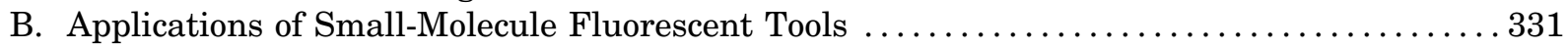

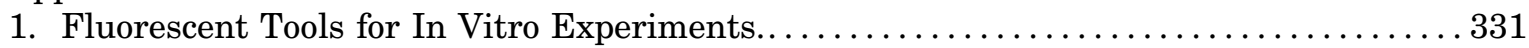

2. Near-Infrared Wavelength Fluorescent Tools for In Vivo Imaging. . . . . . . . . . . . . 334

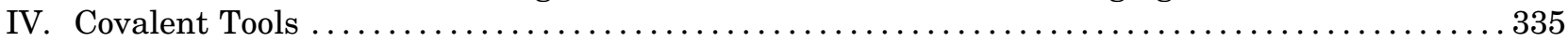

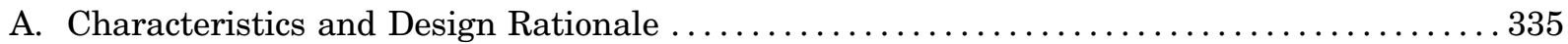

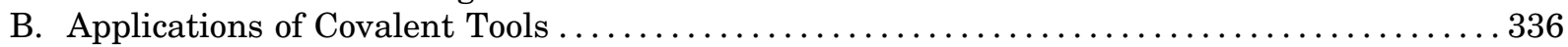

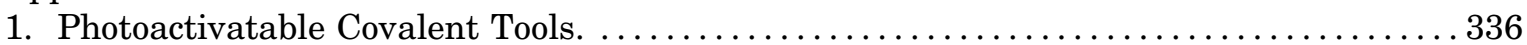

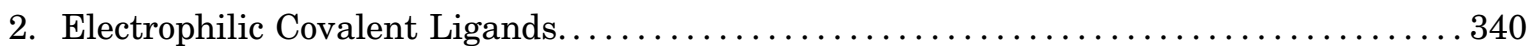

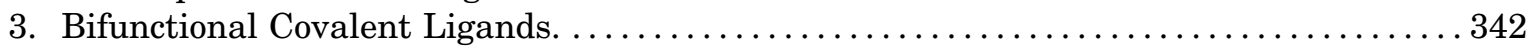

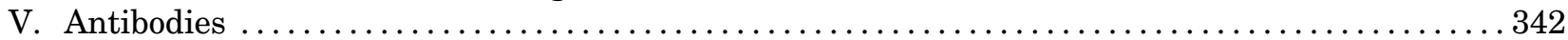

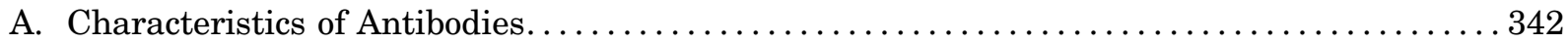

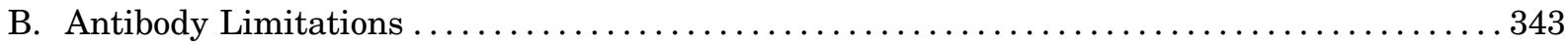

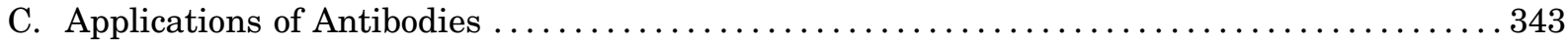

D. Beyond Antibodies................................................... 344

A.C. and S.S. contributed equally to this work.

Address correspondence to: Dr. Andrea J. Vernall, School of Pharmacy, University of Otago, 18 Frederick Street, PO Box 56, Dunedin 9054, New Zealand. E-mail: andrea.vernall@otago.ac.nz

https://doi.org/10.1124/pr.116.013243. 


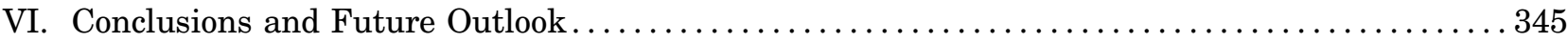

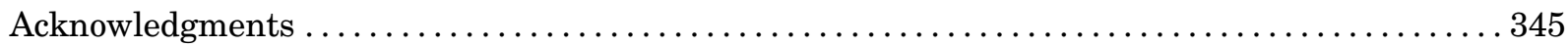

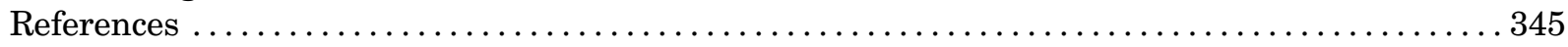

Abstract —CCannabinoid, free fatty acid, lysophosphatidic acid, sphingosine 1-phosphate, prostanoid, leukotriene, bile acid, and platelet-activating factor receptor families are class $A$ G protein-coupled receptors with endogenous lipid ligands. Pharmacological tools are crucial for studying these receptors and addressing the many unanswered questions surrounding expression of these receptors in normal and diseased tissues. An inherent challenge for developing tools for these lipid

\section{Introduction}

Cannabinoid (CB), free fatty acid (FFA), lysophosphatidic acid (LPA), sphingosine 1-phosphate (S1P), prostanoid (DP, EP, FP, IP, TP), leukotriene [leukotriene B(4) (LTB4), cysteinyl leukotriene (CysLT), oxoeicosanoid (OXE), formyl peptide receptor (FPR)2], bile acid receptor (GPBA receptor), and platelet-activating factor (PAF) receptors are class A G protein-coupled receptors (GPCRs) that are activated by lipid-derived endogenous ligands. GPCRs are the largest family of transmembrane-signaling proteins in the human genome and convey signals from a wide range of stimuli, including neurotransmitters, peptide hormones, and autocrine factors (Katritch et al., 2012), thus offering huge potential for disease therapy (Jacobson, 2015). Chemical tools are invaluable for interrogating GPCR structure and physiologic role, which facilitates efficacious drug development. GPCRs can mediate different signaling pathways and are dynamic, flexible, and sensitive to many proximal stimuli (Kobilka and Deupi, 2007); therefore, studies using live cells in native environments often reveal more relevant information. However, scientists face challenges with GPCR research, including very low receptor expression levels in native endogenous cells and tissues (Fredriksson and Schiöth, 2005). In addition, GPCRs are difficult to crystallize due to conformational flexibility, a fluid native membrane environment, and lack of stability in detergents (Salom et al., 2013). In spite of this, the number of reported GPCR crystal structures has exploded in recent years, opening up opportunities for rational structure-based design of drugs and tools (Cooke et al., 2015; Ghosh et al., 2015). Although $\mathrm{X}$-ray crystallography offers invaluable insights into receptors is balancing the often lipophilic requirements of the receptor-binding pharmacophore with favorable physicochemical properties to optimize highly specific binding. In this study, we review the radioligands, fluorescent ligands, covalent ligands, and antibodies that have been used to study these lipid-binding receptors. For each tool type, the characteristics and design rationale along with in vitro and in vivo applications are detailed.
GPCR structure, the static nature somewhat limits the use in unraveling dynamic receptor processes. The chemical tools for CB, FFA, LPA, S1P, prostanoid, leukotriene, GPBA, and PAF receptors discussed in this review can help elucidate receptor physiologic role and dynamic signaling events in live cells and in native environments, thus complementing available structural information.

\section{A. Cannabinoid Receptor}

Two $\mathrm{CB}$ receptor subtypes $\left(\mathrm{CB}_{1}\right.$ and $\left.\mathrm{CB}_{2}\right)$, endocannabinoid (ECB) endogenous ligands, and the corresponding regulatory enzymes are part of the ECB system (Katona and Freund, 2012). $\mathrm{CB}_{1}$ receptor (the then only identified $\mathrm{CB}$ receptor) was characterized in 1988 through investigation of binding of the known CB receptor radioligand $\left[{ }^{3} \mathrm{H}\right] \mathrm{CP}-55,940$ (Fig. 1; Table 1) in rat brain membranes (Devane et al., 1988), and it was cloned in 1990 (Matsuda et al., 1990). $\mathrm{CB}_{1}$ receptor is abundant in the brain, particularly on central and peripheral neurons in the presynapse (Kano et al., 2009), postsynaptic cells, and astrocytes (Castillo et al., 2012), and is found in low levels in peripheral organs (Engeli et al., 2005). $\mathrm{CB}_{1}$ receptor can activate multiple, diverse signaling pathways; for example, it can couple with $\mathrm{G}_{\mathrm{i}}, \mathrm{G}_{\mathrm{s}}$, and/or $\mathrm{G}_{\mathrm{q}}$ proteins (Bosier et al., 2010) and modulate calcium and potassium channels. $\mathrm{CB}_{2}$ receptor was cloned from spleen in 1993 (Munro et al., 1993) and is expressed predominantly in immune cells, lymphoid tissues, such as the spleen and tonsils (Galiegue et al., 1995), and at low levels in central nervous system (CNS) tissues such as microglial cells (Savonenko et al., 2015). Two crystal structures of the human $\mathrm{CB}_{1}$ receptor have recently been published, one complexed with a modified rimonabant-based

ABBREVIATIONS: 2-AG, 2-arachidonylglycerol; 2-AGE, 2-arachidonyl glyceryl ether; ALX, lipoxin A4; AEA, anandamide; BBB, blood brain barrier; BRET, bioluminescence resonance energy transfer; CB, cannabinoid; CNS, central nervous system; CysLT, cysteinyl leukotriene; DBT, delayed brain tumor; ECB, endocannabinoid; FAAH, fatty acid amide hydrolase; FFA, free fatty acid; FPR, formyl peptide receptor; GPBA receptor, bile acid receptor; GPCR, G protein-coupled receptor; gp, guinea pig; h, human; HEK, human embryonic kidney; IHC, immunohistochemistry; LPA, lysophosphatidic acid; LTB4, leukotriene B(4); mAb, monoclonal antibody; MS, multiple sclerosis; NBD, nitrobenzoxadiazole; NIR, near-infrared; OXE, oxoeicosanoid; pAb, polyclonal antibody; PAF, platelet-activating factor; PET, positron emission tomography; PG, prostaglandin; P-gp, P-glycoprotein; r, rat; S1P, sphingosine 1-phosphate; SAR, structure-activity relationship; SPECT, single-photon emission computed tomography; $\mathrm{t}_{1 / 2}$, half-life; THC, $\Delta^{9}$-tetrahydrocannabinol; TMH, transmembrane helix. 
antagonist (Hua et al., 2016) and the other with the inverse agonist taranabant (Shao et al., 2016).

$\mathrm{CB}$ receptors are implicated in an array of physiologic processes and disorders, not limited to the following: pain, inflammation, anxiety, obesity, anorexia, drug addiction, cardiovascular disease, stroke, epilepsy, Alzheimer's disease, Huntington's disease, motor neuron disease, multiple sclerosis (MS), Parkinson's disease, and cancer (reviewed in Pacher and Kunos, 2013). Selective targeting of $\mathrm{CB}_{2}$ receptor holds promise for treating chronic pain perhaps without (or with reduced) the CNS-mediated psychoactive side effects often associated with $\mathrm{CB}_{1}$ receptor activation (Dhopeshwarkar and Mackie, 2014). This, along with promise in other therapeutic areas, is therefore driving development of chemical tools to better understand how $\mathrm{CB}$ receptor expression and function can vary between cell types and healthy and diseased tissue.

1. Ligand Classes. The ECBs anandamide (AEA) (Devane et al., 1992) and 2-arachidonylglycerol (2-AG) (Mechoulam et al., 1995; Sugiura et al., 1995) are endogenous CB receptor ligands. Cannabis has been known for its medicinal properties for thousands of years, and in 1964 the major psychoactive component $\Delta^{9}$-tetrahydrocannabinol (THC), a partial CB receptor agonist, was characterized (Gaoni and Mechoulam, 1964). Many synthetic high-affinity selective agonists, antagonists, and some allosteric ligands for CB receptors have been developed and have been reviewed

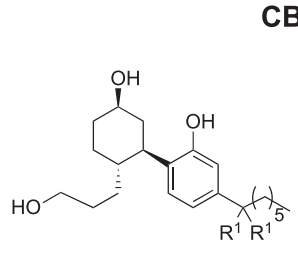

CP-55,940, $\mathrm{R}^{1}=\mathrm{H}$ $\left[{ }^{3} \mathrm{H}\right] \mathrm{CP}-55,940, \mathrm{R}^{1}={ }^{3} \mathrm{H}$

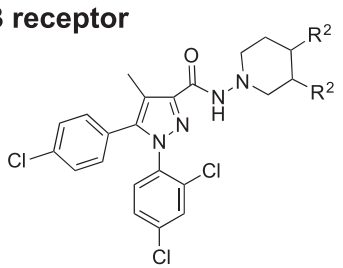

SR141716A, $R^{2}=H$ $\left[{ }^{3} \mathrm{H}\right] \mathrm{SR}$ 141716A, $\mathrm{R}^{2}={ }^{3} \mathrm{H}$
FFA1 receptor

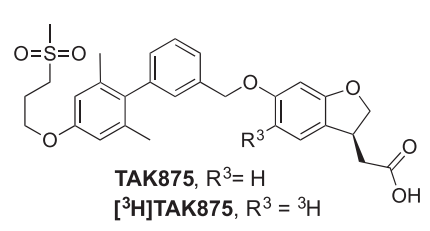

$\mathrm{DP}_{2}$ receptor

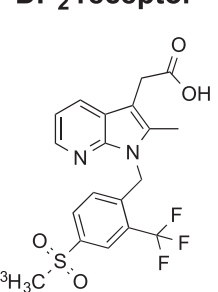

$\left[{ }^{3} \mathrm{H}_{3}\right.$ ]QAW039

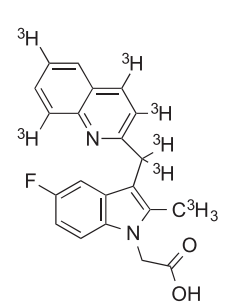

$\left[{ }^{3} \mathrm{H}\right] \mathrm{OC}-459$

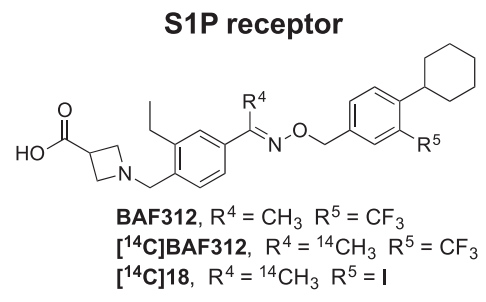

IP receptor

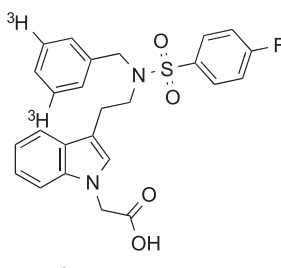

$\left[{ }^{3} \mathrm{H}\right]$ TRQ11238

TP receptor

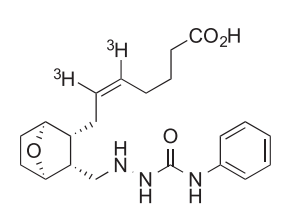

$\left[{ }^{3} \mathrm{H}\right] \mathrm{SQ}-29548$

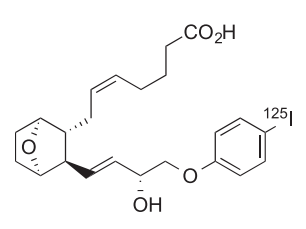

${ }^{[125}$ ] BOP

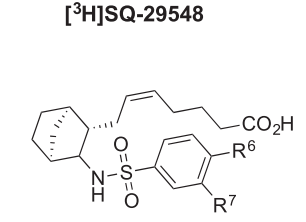

$\left[{ }^{3} \mathrm{H}\right] \mathrm{S}-145, \mathrm{R}^{6}={ }^{3} \mathrm{H}, \mathrm{R}^{7}=\mathrm{H}$ $\left[{ }^{125} \mid\right] \mid-S-145-O H, R^{6}=O H, R^{7}=125$ |

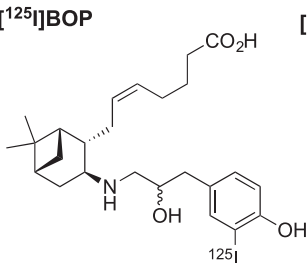

[ ${ }^{125}$ I]PTA-OH

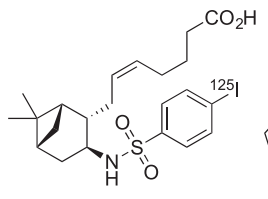

[125I]SAP

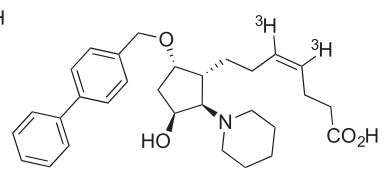

[ $\left.{ }^{3} \mathrm{H}\right] \mathrm{GR} 32191$
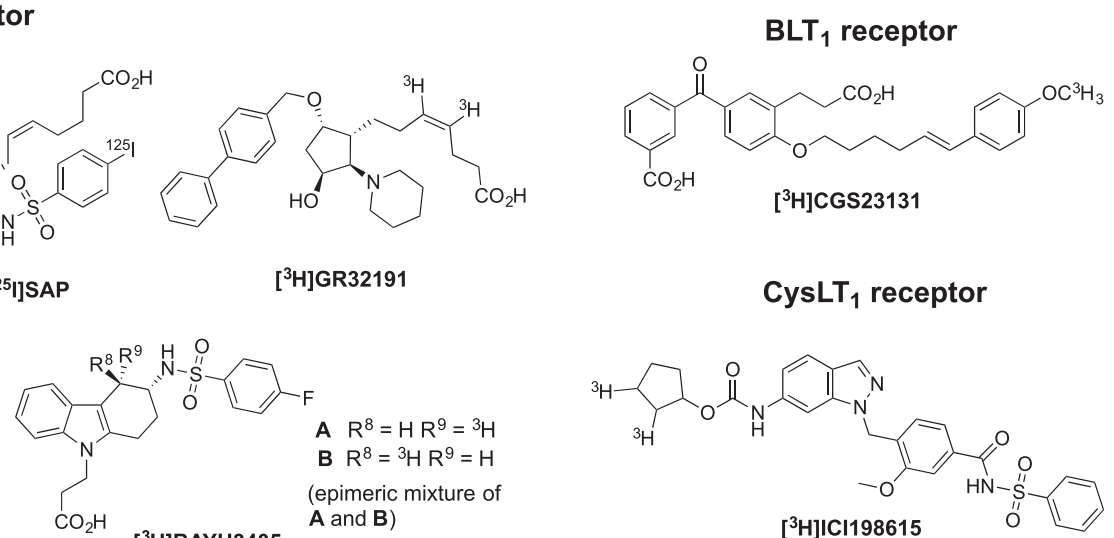

$\left[{ }^{3} \mathrm{H}\right] B A Y U 3405$

(epimeric mixture of

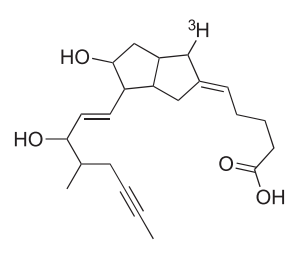

$\left[{ }^{3} \mathrm{H}\right]$ iloprost

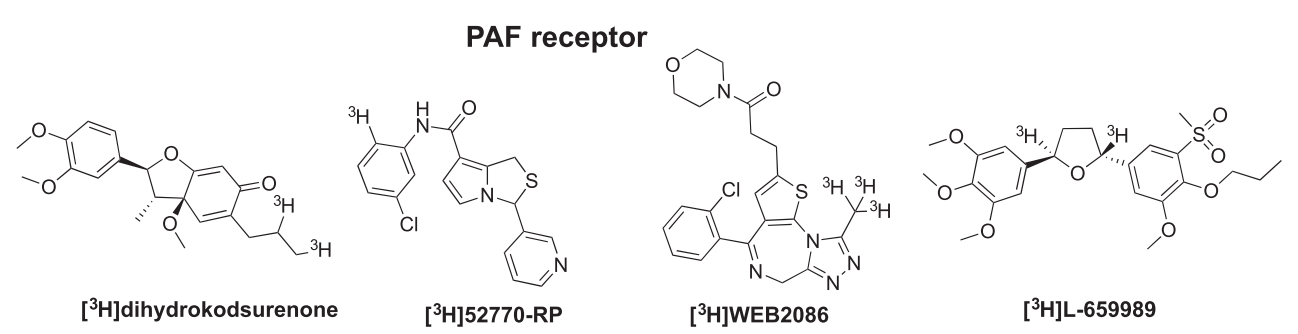

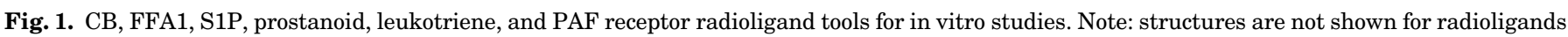
with unknown radioisotope position. 
TABLE 1

$\mathrm{CB}, \mathrm{FFA}, \mathrm{S} 1 \mathrm{P}$, leutokriene, prostanoid, and PAF receptor radioligands for in vitro experiments

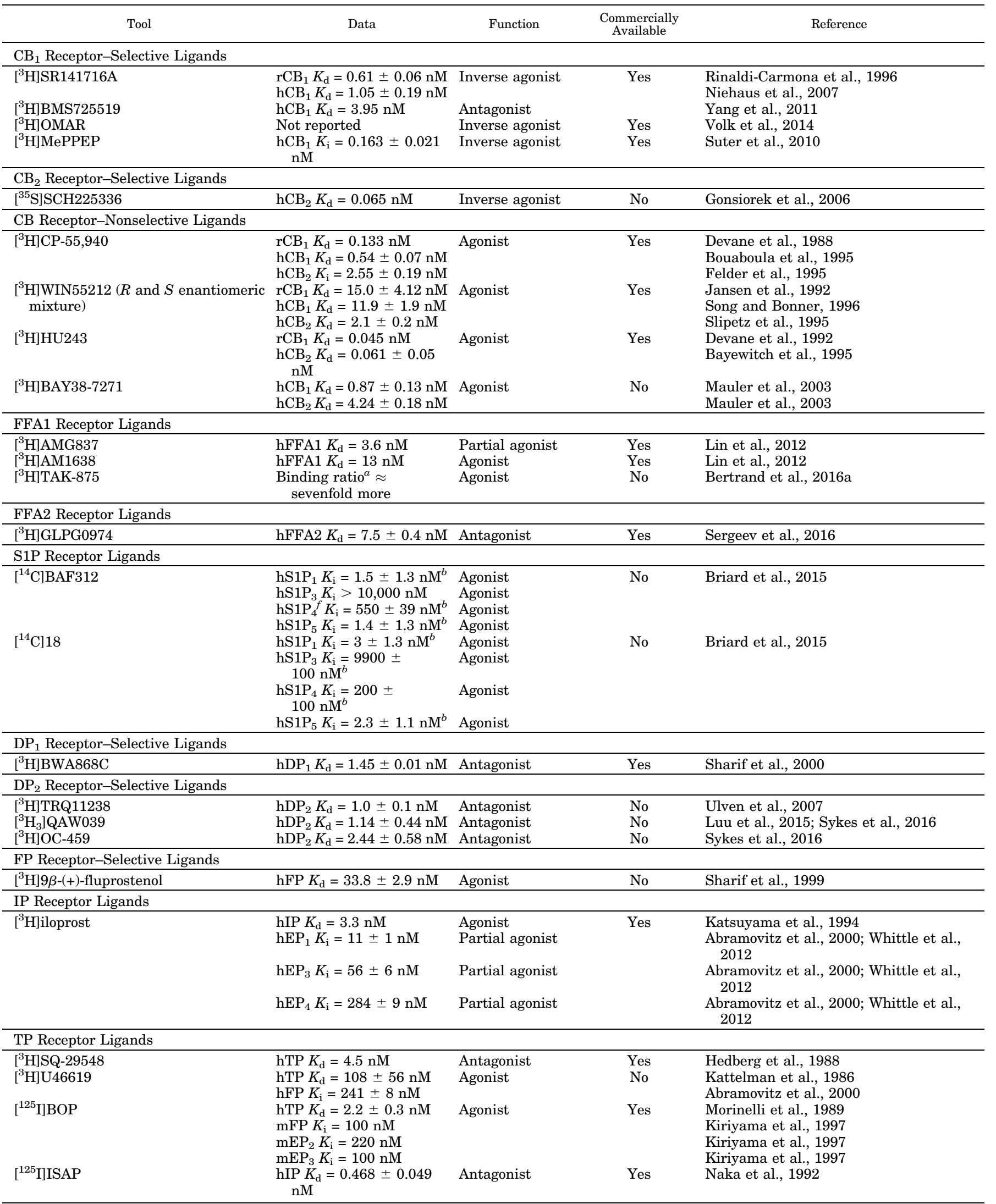


TABLE 1-Continued

\begin{tabular}{|c|c|c|c|c|}
\hline Tool & Data & Function & $\begin{array}{l}\text { Commercially } \\
\text { Available }\end{array}$ & Reference \\
\hline$\left[{ }^{3} \mathrm{H}\right] \mathrm{GR} 32191$ & $\mathrm{hIP} K_{\mathrm{d}}=2.8 \pm 0.03 \mathrm{nM}$ & Antagonist & No & Armstrong et al., 1993 \\
\hline$\left[{ }^{3} \mathrm{H}\right] \mathrm{S}-145$ & $\mathrm{hTP} K_{\mathrm{d}}=0.75 \pm 0.25 \mathrm{nM}$ & Antagonist & No & Hanasaki et al., 1989 \\
\hline$\left[{ }^{3} \mathrm{H}\right] \mathrm{ONO} 3708$ & $\mathrm{hTP} K_{\mathrm{d}}=3.7 \pm 1.4 \mathrm{nM}$ & Antagonist & No & Hanasaki et al., 1989 \\
\hline$\left[{ }^{125} \mathrm{I}\right] \mathrm{I}-\mathrm{S}-145-\mathrm{OH}$ & $\mathrm{hTP} K_{\mathrm{d}}=5.72 \mathrm{nM}$ & Not determined & No & Ushikubi et al., 1989 \\
\hline$\left[{ }^{125} \mathrm{I}\right] \mathrm{PTA}-\mathrm{OH}$ & $\mathrm{hTP} K_{\mathrm{d}}=22.1 \pm 2.3 \mathrm{nM}$ & Antagonist & No & Narumiya et al., 1986 \\
\hline$\left[{ }^{3} \mathrm{H}\right] \mathrm{BAYU} 3405$ & $\mathrm{hTP} K_{\mathrm{d}}=6 \pm 2.5 \mathrm{nM}$ & Antagonist & No & Theis et al., 1992 \\
\hline & $\mathrm{hDP}_{2} K_{\mathrm{d}}=7.2 \pm 2.5 \mathrm{nM}$ & & & Sugimoto et al., 2005 \\
\hline \multicolumn{5}{|l|}{ LTB4 $_{1}$ Receptor Ligands } \\
\hline$\left[{ }^{3} \mathrm{H}\right] \mathrm{CGS} 23131$ & $\mathrm{hLTB}_{1} K_{\mathrm{d}}=13 \pm 1 \mathrm{nM}$ & Antagonist & No & Jackson et al., 1992; \\
\hline \multicolumn{5}{|l|}{ CysLT $_{1}$ Receptor Ligands } \\
\hline$\left[{ }^{3} \mathrm{H}\right] \mathrm{ICI} 198615$ & $\begin{array}{l}\operatorname{gpCysLT}_{1} K_{\mathrm{d}}=0.08 \pm \\
0.04 \mathrm{nM}\end{array}$ & Antagonist & No & $\begin{array}{l}\text { O'Sullivan and Mong, 1989; Alexander } \\
\text { et al., } 2013\end{array}$ \\
\hline \multicolumn{5}{|l|}{ PAF Receptor Ligands } \\
\hline$\left[{ }^{3} \mathrm{H}\right]$ dihydrokadsurenone & $\begin{array}{l}\operatorname{rbtPAF} K_{\mathrm{d}}=16.81 \pm 0.57 \\
\mathrm{nM}\end{array}$ & Antagonist & No & Hwang et al., 1986 \\
\hline$\left[{ }^{3} \mathrm{H}\right] 52770 \mathrm{RP}$ & $\mathrm{hPAF} K_{\mathrm{d}}=4.2 \pm 0.3 \mathrm{nM}$ & Antagonist & No & Marquis et al., 1988 \\
\hline$\left[{ }^{3} \mathrm{H}\right]$ WEB2086/ $\left[{ }^{3} \mathrm{H}\right]$ apafant & $\mathrm{hPAF} K_{\mathrm{d}}=6.1 \mathrm{nM}$ & Antagonist & Yes & Ukena et al., 1988 \\
\hline$\left[{ }^{3} \mathrm{H}\right] \mathrm{L}-659989$ & $\begin{array}{l}\operatorname{rbtPAF} K_{\mathrm{d}}=1.60 \pm 0.20 \\
\mathrm{nM}\end{array}$ & Antagonist & No & Hwang et al., 1989 \\
\hline$\left[{ }^{3} \mathrm{H}\right] \mathrm{SR} 27417$ & $\underset{\mathrm{nM}}{\operatorname{gpPAF} K_{\mathrm{d}}}=0.094 \pm 0.007$ & Antagonist & No & Herbert, 1992 \\
\hline
\end{tabular}

${ }^{a}$ Ratio of binding of $\left[{ }^{3} \mathrm{H}\right]$ TAK875 to GPR40-HEK (HEK 293 cells expressing FFA1 receptor) relative to binding of $\left[{ }^{3} \mathrm{H}\right]$ TAK875 to wild-type HEK 293 , which do not natively express FFA1 receptor.

${ }^{b}$ Affinity data for cold analogs (corresponding $\left[{ }^{12} \mathrm{C}\right]$ derivative).

elsewhere (Pertwee, 2000; Pertwee et al., 2010; Vemuri and Makriyannis, 2015). It must be noted that, although these ligands themselves can be considered chemical tools that can be used to study CB receptor, they have not been included in this review. However, some of these ligands are the basis of chemical tools, such as radioligands and fluorescent and covalent ligands, which are reviewed in this work.

There are a handful of approved drugs; for example, the $\mathrm{CB}$ receptor agonists dronabinol (THC) and nabilone (THC analog) are prescribed for nausea and vomiting in cancer chemotherapy, and Sativex (THC and cannabidiol) for neuropathic pain and spasticity in MS (Pertwee, 2012). In 2006, the $\mathrm{CB}_{1}$ receptor inverse agonist rimonabant was licensed in the European Union and several South American countries (but never in the United States) to treat obesity but was withdrawn in 2009 due to side effects such as depression and suicidal ideation.

\section{B. Free Fatty Acid Receptor}

There are four characterized FFA receptor subtypes. Each receptor can transduce signals via coupling to various $\mathrm{G}$ proteins and through $\mathrm{G}$ protein-independent signaling, such as via $\beta$-arrestin pathways (reviewed in Milligan et al., 2017). FFA1 receptor, known at the time as GPR40, was identified in 2003 (Briscoe et al., 2003; Itoh et al., 2003; Kotarsky et al., 2003) and is expressed in high levels in pancreatic $\beta$ and $\alpha$ cells, monocytes, and various enteroendocrine and nervous system cells (reviewed in Mancini and Poitout, 2013). FFA1 receptor expression and its role in the brain is an area of ongoing interest (Khan and He, 2017). FFA2 and FFA3 receptors were identified in 2003 as the then GPR43 and
GPR41, respectively (Brown et al., 2003; Le Poul et al., 2003), and are expressed in gut, immune cells, adipose tissue, and the peripheral nervous system. FFA4 receptor, which shares the least sequence homology compared with FFA1-3 receptors, was reported in 2005 (Hirasawa et al., 2005) as the then named GPR120 and has been found in many tissues such as intestinal, gastric, adipose, and liver. The crystal structure of FFA1 receptor bound to the allosteric agonist ligand TAK-875 (Fig. 1) has been reported (Srivastava et al., 2014). The relatively recent deorphanization of FFA receptors means their role in disease and therapeutic intervention has not yet been fully realized. Recognition of dietary FFAs and how these enable cross-talk between energy metabolism (Hara et al., 2014) and the immune system has implications for many conditions such as type II diabetes and obesity (reviewed in Milligan et al., 2014; Alvarez-Curto and Milligan, 2016).

1. Ligand Classes. As the name suggests, FFAs are ligands for FFA receptors. Medium- and long-chain FFAs have higher potency at FFA1 and FFA4 receptors, whereas shorter-chain FFAs have higher potency at FFA2 and FFA3 receptors (Brown et al., 2003; Stoddart et al., 2008; Christiansen et al., 2015; Milligan et al., 2017). FFAs can be released in the body as the result of triglyceride breakdown and bacterial-mediated carbohydrate breakdown, or consumed in the diet. Despite some structure-activity relationship (SAR) trends, many FFAs bind to more than one FFA receptor subtype, thus making characterizing and understanding FFA receptors challenging (Hudson et al., 2011). A greater number of synthetic ligands for FFA1 receptor has been reported compared with other receptor subtypes, and, of those, there are many more agonists than antagonists (reviewed 
in Milligan et al., 2015, 2017; Tikhonova and Poerio, 2015). This mirrors research efforts that suggest agonists of FFA1 receptor may be of benefit therapeutically. TAK875 (or fasiglifam) (Fig. 1), a FFA1 receptor agonist, underwent Phase III clinical trials and showed improved glycaemic control in type II diabetic patients, but was not progressed further due to safety concerns (Kaku et al., 2015).

\section{Lysophospholipid Receptors}

LPA and S1P receptors were first classified as endothelial differentiation gene receptors and later divided into two classes based on endogenous ligand preference (Chun et al., 2002). There are five characterized S1P receptors $\left(\mathrm{S}_{1} \mathrm{P}_{1}-\mathrm{S}_{1} \mathrm{P}_{5}\right)$ and six characterized LPA receptors $\left(\mathrm{LPA}_{1}-\mathrm{LPA}_{6}\right)$. Originally named endothelial differentiation gene $1, \mathrm{~S}_{1} \mathrm{P}_{1}$ receptor was first characterized in 1990 (Hla and Maciag, 1990). $\mathrm{S}_{1} \mathrm{P}_{1}-\mathrm{S}_{1} \mathrm{P}_{3}$ receptors are ubiquitously expressed (Blaho and Hla, 2014), whereas $\mathrm{S}_{1} \mathrm{P}_{4}$ and $\mathrm{S}_{1} \mathrm{P}_{5}$ receptors are found in distinct cell types such as lymphoid, hematopoietic oligodendrocyte lineage cells, and in lung tissue (Gräler et al., 1998; Terai et al., 2003). As is the case for LPA receptors, different S1P receptor subtypes all couple to different combinations of $G$ proteins (as reviewed in Kihara et al., 2015), and presumably also use yet to be fully characterized G protein-independent signaling mechanisms. The first of the LPA receptors was identified in 1996 (Hecht et al., 1996), and the expression and signaling have been recently reviewed (Contos et al., 2000; Choi et al., 2010; Fukushima et al., 2015; Stoddard and Chun, 2015). In brief, $\mathrm{LPA}_{1}$ and $\mathrm{LPA}_{3}-\mathrm{LPA}_{6}$ receptors are widely expressed, whereas $\mathrm{LPA}_{2}$ receptor expression is comparatively more limited, with higher levels found in testis and leukocytes. The crystal structure of $\mathrm{S}_{1} \mathrm{P}_{1}$ receptor (Hanson et al., 2012) and, more recently, $\mathrm{LPA}_{1}$ receptor (Chrencik et al., 2015) has been reported, both using a highaffinity antagonist.

$\mathrm{S} 1 \mathrm{P}_{1}$ receptor signaling regulates human $\mathrm{B}$ cell tissue distribution, thereby opening avenues to treat MS, leukemia, and certain immunodeficiencies (Sic et al., 2014; Farez and Correale, 2016). S1P or LPA receptor modulation (reviewed in Mutoh et al., 2012) may be of therapeutic benefit for many areas, not limited to the following: treatment of cancer and autoimmune disorders such as systemic sclerosis and arthritis (Stoddard and Chun, 2015); fibrotic disease of the kidney, liver, lung, and skin (Kihara et al., 2015); infectious disease (Arish et al., 2016); ischemic vascular disease (AbdelLatif et al., 2015); and neurotrauma and Alzheimer's disease (Choi and Chun, 2013). A greater understanding of receptor expression and dynamic signaling is required to unlock this potential-for which development of new chemical tools is key.

1. Ligand Classes. S1P (reviewed in Ghasemi et al., 2016) and LPA (reviewed in Stoddard and Chun, 2015;
Yung et al., 2015) are the endogenous lysophospholipids for S1P and LPA receptors, respectively. In brief, both S1P and LPA mediate an enormous array of physiologic process, and, like the ECBs, production of these lipids is tightly regulated in a complex network involving many enzymatic transformations (Tang et al., 2015). Development of synthetic $\mathrm{S} 1 \mathrm{P}$ receptor ligands has been most intensive for $\mathrm{S}_{1} \mathrm{P}_{1}$ receptor; however, selective agonists and some antagonists of other $\mathrm{S} 1 \mathrm{P}$ receptors have been reported and reviewed elsewhere (Blaho and Hla, 2014; Delgado and Martínez-Cartro, 2016). Synthetic ligands for $\mathrm{S}_{1} \mathrm{P}_{1}$ receptor notably include the nonselective agonist prodrug FTY720 (fingolimod), which was the first orally available treatment of relapsing MS (Chun and Hartung, 2010). Predominantly, antagonists have been reported as synthetic ligands for $\mathrm{LPA}_{1}$ and $\mathrm{LPA}_{3}$ receptors; however, many gaps exist in terms of lack of selective agonists and antagonists for the various LPA receptor subtypes (Llona-Minguez et al., 2015). Currently, there are no marketed drugs targeting LPA receptors; however, the $\mathrm{LPA}_{1}$ receptor antagonist BMS986020 is currently in Phase II clinical trials to treat idiopathic pulmonary fibrosis.

\section{Prostanoid Receptor}

There are currently five recognized prostanoid receptor subtypes, DP, EP, FP, IP, and TP receptor, which have been categorized based on the potency of the principal endogenous ligands prostaglandin (PG) or thromboxane, and then further divided into receptor subtypes $\left(\mathrm{DP}_{1}-\mathrm{DP}_{2}, \mathrm{EP}_{1}-\mathrm{EP}_{4}\right.$ receptor). First to be cloned was TP receptor (Hirata et al., 1991) and, most recently, $\mathrm{DP}_{2}$ receptor (Nagata et al., 1999), which, despite sharing $\mathrm{PGD}_{2}$ as an endogenous ligand, possesses little sequence homology to $\mathrm{DP}_{1}$ receptor and has very different functions (Hirai et al., 2001). Prostanoid receptor expression, distribution, and diverse G proteinsignaling pathways are reviewed by Woodward et al. (2011). Briefly, $\mathrm{DP}_{1}$ receptor is expressed in the small intestine and platelets, and at particularly high levels in the retina, whereas $\mathrm{DP}_{2}$ receptor expression is widespread across the digestion system, heart, spinal cord, and blood. $\mathrm{EP}_{1}$ receptor distribution in humans is limited when compared with murine species. In contrast, $\mathrm{EP}_{2}$, $\mathrm{EP}_{3}, \mathrm{EP}_{4}$, and $\mathrm{FP}$ receptors have widespread distribution in humans. TP receptor is expressed in platelets, the cardiovascular system, and smooth muscle. To date, crystal structures have not been reported for prostanoid receptors.

EP receptors have been implicated in tumorigenesis, and, as such, the diverse signaling pathways of EP receptor subtypes are being explored as cancer drug targets (O'Callaghan and Houston, 2015). $\mathrm{EP}_{2}$ receptor has also been investigated as a target for treating inflammation in CNS disease, stroke, and ocular disease (Ganesh, 2014), whereas $\mathrm{EP}_{4}$ receptor has been shown to have roles in immune modulation, 
inflammation, and tissue development (Konya et al., 2013). $\mathrm{DP}_{2}$ receptor is a promising drug target for the treatment of asthma and allergic rhinitis (Santini et al., 2016; Santus and Radovanovic, 2016).

1. Ligand Classes. The endogenous prostaglandins, $\mathrm{PGD}_{2}, \mathrm{PGE}_{2}, \mathrm{pGF}_{2} \alpha, \mathrm{PGI}_{2}$, and thromboxane $\mathrm{A}_{2} /$ precursor $\mathrm{PGH}_{2}$, are involved in a variety of functions, including smooth muscle contraction and relaxation and platelet aggregation. These endogenous ligands are promptly metabolized and therefore act as paracrine or autocrine factors (Smith et al., 2011; Korbecki et al., 2014). There are selective, synthetic agonists, and antagonists for all nine prostanoid receptors (reviewed in (Flesch et al., 2013; Lamers et al., 2013; Santini et al., 2016; Santus and Radovanovic, 2016; Markovič et al., 2017) and approved TP receptor antagonists on the market, including seratrodast for the treatment of asthma (Dogne et al., 2002) and ridogrel for the prevention and treatment of thromboembolism (Vandewerf et al., 1994). Terutroban was investigated as an antiplatelet agent, but the trial was suspended as it was found to be no better than aspirin (Bousser et al., 2011). EP receptor-targeted drugs have a variety of uses, such as misoprostol and sulprostone for ulcer treatment, medical abortion and labor induction (Van Mensel et al., 2009), and iloprost (also targets IP receptor) for treatment of hypertension (Olschewski et al., 2002). EP receptors are being explored as an alternative target for development of anti-inflammatory therapies because specific cyclo-oxygenase-2 (which is involved in the same pathway) inhibitors have been shown to exhibit serious side effects such as myocardial infarction and gastric ulceration (Ganesh, 2014; O'Callaghan and Houston, 2015).

\section{E. Leukotriene Receptor}

The leukotriene family of receptors is classified according to its specificity for the endogenous leukotrienes and consists of two LTB4, two CysLT, one OXE, and one FPR2/lipoxin A4 (ALX) receptor, with LTB4, receptor the first to be cloned (Yokomizo et al., 1997). Both subtypes of LTB4 receptor couple to $G_{i}$ and $G_{q}$, stimulate phospholipase $\mathrm{C}$, and inhibit adenylate cyclase, whereas CysLT $\mathrm{T}_{1-2}$ receptors are $\mathrm{G}_{\mathrm{q}}$-coupled and OXE and FPR2/ALX receptor are $\mathrm{G}_{\mathrm{i}}$-coupled (Bäck et al., 2011; Powell and Rokach, 2013). All leukotriene receptors are expressed in leukocytes (as reviewed by Bäck et al., 2011), with LTB4 $4_{1}$ receptor also expressed in smooth muscle and umbilical cord endothelial cells and $\mathrm{LTB}_{2}$ receptor expressed in spleen, liver, and ovary. CysLT $_{1}$ receptor is expressed in lung, spleen, and smooth muscle, and $\mathrm{CysLT}_{2}$ receptor in adrenal gland, heart, spleen, brain, and spinal cord. OXE receptor is expressed in the digestive system, heart, and lungs, whereas FPR2/ALX receptor is expressed in intestinal epithelial cells, lung, kidney, spleen, and placenta (Bäck et al., 2014). A leukotriene receptor crystal structure is yet to be reported. The leukotriene receptors have a major role in inflammation and have been implicated in CNS disorders (Ghosh et al., 2016), cancer (Burke et al., 2016), allergy (Liu and Yokomizo, 2015), and asthma (Singh et al., 2013b).

1. Ligand Classes. Leukotrienes are the endogenous ligands of these receptors and are primarily inflammatory mediators. Leukotriene levels are tightly regulated by enzymes, including lipoxygenase that converts arachidonic acid to leukotrienes (Murphy and Gijon, 2007). There are a number of selective synthetic agonists and antagonists for the leukotriene receptors, including anti-inflammatory agonists for FRP2/ALX receptor (Corminboeuf and Leroy, 2015; Stalder et al., 2017) and CysLT $\mathrm{T}_{1}$ receptor antagonists for modulation of immune cell function (Theron et al., 2014). There are three CysLT $_{1}$ receptor antagonists currently on the market for treatment of asthma: Pranlukast (Keam et al., 2003), Zafirlukast (Kelloway, 1997), and Montelukast (Paggiaro and Bacci, 2011).

\section{F. Bile Acid Receptor}

GPBA receptor, often called TGR5 receptor, shows the closest sequence homology $(28 \%)$ to $\mathrm{S} \mathrm{P}_{1}$ receptor and signals via endogenous bile acids (Maruyama et al., 2002). This receptor is coupled to $G_{s}$, controlling adenylate cyclase stimulation and protein kinase $\mathrm{A}$ activation (Copple and $\mathrm{Li}, 2016$ ). GPBA is widely expressed in gall bladder, intestine, liver, and enteric neurons (Duboc et al., 2014). GPBA receptor mediates the action of bile acids on glucose homeostasis and inflammation, and is therefore an interesting target for inflammatory and metabolic disorders such as diabetes (Duboc et al., 2014; Lieu et al., 2014). There is no crystal structure available for GPBA receptor.

1. Ligand Classes. The endogenous ligands of GPBA receptors are the bile acids (for example, chenodeoxycholic acid, cholic acid, deoxycholic acid, and lithocholic acid), which principally enable digestion of fats in the intestine, but also mediate insulin secretion, energy expenditure, and immune cell function through GPBA receptor signaling (Copple and $\mathrm{Li}, 2016$ ). There have been a number of selective synthetic agonists developed for GPBA receptor (reviewed in Xu, 2016); however, no drugs have yet come to market that specifically target this receptor.

\section{G. Platelet-Activating Factor Receptor}

The PAF receptor was first cloned in 1991 (Honda et al., 1991). Activation by the endogenous agonist PAF signals via a complex network of $G$ protein-dependent (Honda et al., 1994) and -independent (Lukashova et al., 2001; Chen et al., 2002) transduction pathways. $\mathrm{PAF}$ receptor is widely expressed in immune cells such as neutrophils, macrophages, and B cells, and also in other cell types such as keratinocytes, and, as the origin of the name suggests, platelets (Chao and 
Olson, 1993; http://wwwguidetopharmacologyorg/ GRAC/FamilyIntroductionForward?familyId=55). Several studies have shown the existence of intracellular PAF receptors, with differences in receptor cellular localization most likely resulting in distinct functions (Bhosle et al., 2016), thus adding an extra layer of complexity and potential for drugs targeting a specific receptor population. Historically, most therapeutic intervention via $P A F$ receptor antagonism has been directed at treating conditions associated with inflammation and immunity, for example, asthma (Kasperska-Zajac et al., 2008), allergic conditions (Pałgan and Bartuzi, 2015), and autoimmune diseases (Edwards and Constantinescu, 2009). Due to the extensive pathophysiological role of this receptor, there has been recent interest in targeting PAF receptor for other indications, for example, in reducing human immunodeficiency virus-related comorbidities (Kelesidis et al., 2015) and in the treatment of dengue infections (Souza et al., 2009). A crystal structure of PAF receptor has not yet been reported.

1. Ligand Classes. The endogenous ligand is the proinflammatory phospholipid PAF, which in the 1960s was identified via its role in platelet aggregation and histamine release from activated platelets (Barbaro and Zvaifler, 1966). As is the case for other endogenous lipidsignaling molecules, the production and metabolism of $\mathrm{PAF}$ are highly regulated and complex (as reviewed in Prescott et al., 2000); for example, therapeutic intervention using PAF acethydrolase inhibitor darapladib failed to meet Phase III endpoints (Marathe et al., 2014). Clinical applications of PAF receptor modulation have driven the development of many selective antagonists (reviewed in Koltai and Braquet, 1994 and Feuerstein et al., 1997), and natural products have been reported as PAF receptor antagonists (reviewed in Singh et al., 2013a), of note ginkgolide B (also known as BN 52021). Rupatadine is a dual histamine- 1 and $\mathrm{PAF}$ receptor antagonist clinically used to treat allergic rhinitis and urticarial (Gonzalez-Nunez et al., 2016), whereas several other PAF receptor antagonists are still in clinical trials (e.g., modipafant, which was discontinued for asthma indication but is now under investigation for dengue fever) or have failed in clinical trials/been discontinued (e.g., apafant, lexipafant, foropafant).

\section{H. Orphan G Protein-Coupled Receptors}

Future classification of orphan GPCRs into existing endogenous lipid-binding GPCR families or as new lipid-binding GPCR families is possible. GPR55 is found in CNS tissue, vasculature, and osteoclasts, and is thought to play a role in nociception, cancer, and metabolism (Henstridge, 2012). The endogenous ligand for GPR55 is reported as lysophosphatidylinositol, but sensitivity toward endogenous CBs and some synthetic CB receptor ligands has also been shown (reviewed in
Henstridge et al., 2016), whereas some chemical tools developed for CB receptors turned out to have affinity for GPR55 (Fluorescent Tools for In Vitro Experiments). Endogenous lipid-like ligands have been shown to bind to other class A orphans such as GPR18, GPR84, GPR119, GPR132, and GPR174 in more than one publication (http://www.guidetopharmacology.org/ GRAC/GPCRListForward?class=A).

\section{Rational Design of Tools and Considerations for Use}

A well-characterized ligand with high affinity and selectivity for the target receptor is often selected as the starting point for designing a radioligand, fluorescent, or covalent ligand. GPCRs can exist in multiple conformations (e.g., $\mathrm{R}$ and $\mathrm{R}^{*}$ ), and each conformation may have a different affinity for ligands, such as antagonists, agonists, or allosteric modulators; therefore, end biologic use should be considered early in the design process. Often tool design is aided by structural information, either crystallographic or homology receptor models, and/or knowledge from biologic techniques such as site-directed mutagenesis. For receptors with endogenous or synthetic lipophilic ligands, it is important to balance the inherent requirement for some lipophilicity of the orthosteric pharmacophore to retain receptor affinity and/or efficacy but without undesirable properties such as high levels of nonspecific membrane binding. Promiscuous binding to other GPCRs and cellular proteins also contributes to undesirable nonspecific binding and should be considered in the design process. The receptor selectivity of a chemical tool should be considered in a context-specific manner to enable meaningful use, as selectivity measured in different cell lines overexpressing a given receptor subtype in vitro may not necessarily translate into in vivo selectivity if relative receptor subtype expression is vastly different due to tissue- or disease-induced differences.

Ligand entry into lipid-activated CB (Makriyannis and Rapaka, 1990; Tian et al., 2005; Hurst et al., 2010) and S1P (Hurst et al., 2013) receptors is proposed to be via a lipid portal rather than direct extracellular entry as for other class A GPCRs. This has implications for access of chemical tools such as radioligands, covalent, and fluorescent ligands into the receptor binding site. The generation of antibodies against an antigen is of course a very different process to that of designing chemical tools and requires stable purified protein, often in a certain functional conformation, which can be quite challenging for flexible membraneembedded GPCRs. Depending on availability and suitability, in vitro GPCR research can use cells or tissue from many different species; for example, discussed in this manuscript are human (h), mouse $(\mathrm{m})$, rat ( $\mathrm{r}$ ), bovine (b), guinea pig (gp), and rabbit (rbt) cell lines/tissues. Small variations in sequence can lead to significant differences in potency of a ligand for a receptor (Hudson et al., 2013); therefore, when analyzing 
tools, it is extremely important to consider the receptor species.

\section{Radioligands}

\section{A. Characteristics and Design Rationale}

Radioligands contain a radioisotope such as ${ }^{3} \mathrm{H},{ }^{123} \mathrm{I}$, ${ }^{125} \mathrm{I},{ }^{35} \mathrm{~S},{ }^{11} \mathrm{C}$, and ${ }^{18} \mathrm{~F}$, which undergoes nuclear decay to emit $\beta$ particles, positrons, or $\gamma$ radiation that can be detected and quantified. Sensitivity and shelf life are determined by specific activity and half-life $\left(t_{1 / 2}\right)$ of the radioisotope; for example, ${ }^{125} \mathrm{I}$ has a specific activity of $2200 \mathrm{Ci} / \mathrm{mmol}$ and a $\mathrm{t}_{1 / 2}$ of 60 days compared with ${ }^{3} \mathrm{H}$ with a specific activity of $120 \mathrm{Ci} / \mathrm{mmol}$ and a 12 -year $\mathrm{t}_{1 / 2}$. It should be noted that these specific activities are representative and will vary across batches. More commonly, ${ }^{3} \mathrm{H}$ radioligands have been used to study CB, FA, LPA, S1P, prostanoid, leukotriene, GPBA, and PAF receptors, due to commercial availability and the ${ }^{3} \mathrm{H}-{ }^{1} \mathrm{H}$ interchange leading to little chemical change, thus preserving biologic activity and better relative safety over other radioisotopes. Radioisotopes are chemically incorporated, for example, through reaction of a phenolic ligand with $\left[{ }^{11} \mathrm{C}\right]$ methyl iodide or catalytic reduction of an alkene with tritium gas.

For GPCRs with lipid-like endogenous ligands, it is often challenging to design suitable radioligands that possess sufficient polarity to negate high levels of nonspecific membrane binding. For example, most CB receptor radioligands for in vivo imaging are lipophilic compounds with $\log D_{7.4}$ in the range of 3.3-6.0. Highaffinity radioligands with subnanomolar $K_{\mathrm{d}}$ values are preferred, as they can be used effectively at lower concentrations (Bigott-Hennkens et al., 2008). As with many other chemical tools, the researcher can select a tool that is most advantageous to his or her study - this could be an agonist, antagonist, or inverse agonist. Currently, there are reported radiolabeled allosteric tools for studying FFA1 receptor but not for other lipid-binding GPCRs discussed in this work; future development, for example, of a radiolabeled ORG27569 (Fig. 6), a CB receptor allosteric ligand, would prove very interesting.

\section{B. Applications of Radioligands}

Radioligands have been used extensively to study GPCR pharmacology, for example, distribution, signaling, oligomerisation, allosteric modulation, and in binding assays for screening novel ligands. Radioligands have been used in saturation, competition, or kinetic binding assays to determine various ligand-receptor parameters such as $K_{\mathrm{d}}, K_{\mathrm{i}}$, and $B_{\max }$. There are also in vivo applications such as positron emission tomography (PET) and single-photon emission computed tomography (SPECT). High-affinity and excellent radioligand receptor subtype specificity are especially important with low levels of receptor expression and to avoid toxicity and radiation hazards. Limitations inherent to radioligands include legal and safety requirements surrounding handling, disposal, synthesis, and/or storage, and the need for specialized equipment and facilities to address this, along with natural radioactive decay that limits shelf life.

1. Radioligands for In Vitro Experiments. Rather than an exhaustive commentary of all radioligands and uses, this review describes the commonly used in vitro radioligands based on synthetic scaffolds (Fig. 1; Table 1) and describes selected studies that showcase the utility of these radioligands. It should be noted that many radiolabeled lipids are commercially available and have been used to study receptor and endogenous ligand trafficking, for example $\left[{ }^{33} \mathrm{P}\right] \mathrm{S} 1 \mathrm{P}$ (Jo et al., 2012), $\left[{ }^{3} \mathrm{H}\right] \mathrm{LPA}$ (Thomson et al., 1994), $\left[{ }^{3} \mathrm{H}\right] \mathrm{AEA}$ (Hillard et al., 1997), $\left[{ }^{3} \mathrm{H}\right] \mathrm{PGE}_{2}$ (Nemoto et al., 1997), $\left[{ }^{3} \mathrm{H}\right] \mathrm{PGD}_{2}$ (Matsuo and Cynader, 1993), $\left[{ }^{3} \mathrm{H}\right] \mathrm{LTB}_{4}$ (Toda, 1999), $\left[{ }^{3} \mathrm{H}\right] 5$-oxo-ETE (O'Flaherty et al., 1998), and $\left[{ }^{3} \mathrm{H}\right] \mathrm{PAF}$ (Nakamura et al., 1991). Although these labeled endogenous ligands can be useful tools for interrogating receptor pharmacology (Hecht et al., 1996; Parrill et al., 2000; Van Brocklyn et al., 2000), they often suffer from rapid enzymatic degradation even in in vitro experiments. In this study, we review only radiolabeled synthetic ligands.

In 1964, THC was identified as a $\mathrm{CB}_{1}$ receptor ligand, and soon after it was ${ }^{14} \mathrm{C}$-labeled to provide the first CB receptor radioligand $\left[{ }^{14} \mathrm{C}\right] \mathrm{THC}$ (Miras, 1965). Since then a number of THC-based CB receptor radioligands have been developed (Agurell et al., 1969; Pitt et al., 1980; Nye et al., 1985); however, nowadays these are not commonly used due to high nonspecific membrane binding.

Autoradiographic studies of receptor distribution can be carried out in vitro; for example, an early report using the $\mathrm{CB}$ receptor radioligand $\left[{ }^{3} \mathrm{H}\right] \mathrm{CP}-55,940$ (Fig. 1 ; Table 1) found the highest $\mathrm{CB}_{1}$ receptor density in substantia nigra, basal ganglia, globus pallidus, cerebellum, and hippocampus regions that are known to control cognitive and motor functions (Herkenham et al., 1990; Glass et al., 1997). An interesting recent example of a competition-binding assay using $\left[{ }^{3} \mathrm{H}\right] \mathrm{CP}-55,940$ is the evaluation of approximately 50 compounds from the herbal mixture known as "Spice," previously shown or assumed to be a $\mathrm{CB}_{1}$ agonist (Hess et al., 2016). Many new structural analogs of cannabinoids have emerged in recent years designed to circumvent legally defined chemical classes, with little accompanying pharmacological evaluation. Hess et al. (2016) carried out radioligandbinding assays using $\left[{ }^{3} \mathrm{H}\right] \mathrm{CP}-55,940$, which revealed most compounds had low to subnanomolar affinity for $\mathrm{CB}_{1}$ and $\mathrm{CB}_{2}$ receptors, and further functional assays showed these to be agonists.

$\mathrm{CB}$ receptor affinity determined by a radioligand competition-binding assay is often the first parameter by which ligands are ranked despite the sometimes little structural similarity between radioligand and test 
ligand. A recent report has highlighted some important things to note when using a universal radioligand for investigating binding of ligands to $\mathrm{CB}_{2}$ receptor (Smoum et al., 2015). Smoum et al. (2015) reported that HU-433, the enantiomer of the well-studied HU-308, had 25-fold reduced binding affinity to $\mathrm{CB}_{2}$ receptor (as measured using a competition assay with $\left[{ }^{3} \mathrm{H}\right] \mathrm{CP}$ $55,940)$ but had much higher potency in osteoblast proliferation and anti-inflammatory experiments compared with HU-308. It was proposed that HU-433 and HU-308 may bind to $\mathrm{CB}_{2}$ receptor in different orientations, thus turning on different downstream signaling pathways and competing with $\left[{ }^{3} \mathrm{H}\right] \mathrm{CP}-55,940$ nonequally. This study serves as a reminder that measured compound affinity for a receptor is only ever in relation to the reference, and sometimes the choice of reference or radioligand tool can influence not just the raw number but also the rank order of ligands.

Radioligands are crucial tools for investigating the existence of multiple GPCR states. For example, it was estimated that $\mathrm{CB}$ receptors are present in a $70 \%$ inactive:30\% active conformation in rat cerebellar membrane using the agonist $\left[{ }^{3} \mathrm{H}\right] \mathrm{CP}-55,940$ that bound only to active rat (r) CB1 receptor and the inverse agonist $\left[{ }^{3} \mathrm{H}\right]$ SR141716A (Fig. 1; Table 1) that bound to $\mathrm{rCB}_{1}$ receptors in both active and inactive states (Kearn et al., 1999). Radioligands are also important tools for identifying key receptor amino acids, for example, direct comparison of radioligand binding to wild-type versus mutant receptor. In one study, modified human (h) $\mathrm{CB}_{1}$ receptors were constructed with residues D2.63 and K373 mutated to Ala or the reciprocal Asp/Lys mutation to investigate the importance of an ionic interaction (Marcu et al., 2013). [The residue numbering system used is based on the Ballesteros-Weinstein numbering scheme, whereby the single-letter code of the amino acid is followed by the transmembrane helix (TMH) number, and then the amino acid's position relative to the TMH's most conserved residue (assigned as 50)]. The $K_{\mathrm{d}}, B_{\max }$, and $K_{\mathrm{i}}$ of $\left[{ }^{3} \mathrm{H}\right] \mathrm{SR} 141716 \mathrm{~A}$ were measured for wild-type receptor and for each receptor mutant, and, interestingly, no significant difference in binding was observed. However, a GTP $\gamma$ S-binding assay indicated signaling was impaired in each Ala receptor mutant, but not in the reciprocal Asp/Lys mutant, with the authors suggesting the ionic interaction between D2.63 and K373 influences the EC-3 loop and is important for CB receptor signaling.

The physiologic relevance of GPCR oligomerization is not yet fully understood, and radioligands have been used as tools to shed light on this; for example, a selective adenosine $2 \mathrm{~A}$ receptor agonist CGS21680 decreased the $B_{\max }$ of the $\mathrm{CB}_{1}$ receptor radioligand $\left[{ }^{3} \mathrm{H}\right]$ SR141716A in synaptosomal membrane of rat brain from $3.23 \pm 0.17$ pmol. $\mathrm{mg}^{-1}$ to $2.68 \pm 0.18$ pmol.mg ${ }^{-1}$ (Ferreira et al., 2015). This was attributed to inhibition of $\mathrm{CB}_{1}$ receptor signaling by adenosine $\mathrm{A}_{\mathrm{A}}$ receptor, with the authors suggesting that dual targeting of these receptors may prove therapeutically beneficial. Despite radioligands having utility for investigating GPCR oligomerization, fluorescent tools are often superior for this line of investigation, as bioluminescence resonance energy transfer (BRET) and fluorescence resonance energy transfer experiments can provide precise spatial information (Applications of Small-Molecule Fluorescent Tools). Allosteric binding sites of CB, FFA, prostanoid, and $\mathrm{S} 1 \mathrm{P}$ receptors have been interrogated using radioligand tools. In one example, $\mathrm{a} \mathrm{CB}_{1}$ receptor radioligand-binding assay carried out in the presence of compounds such as ORG27569 (Fig. 6) increased the binding affinity of the agonist $\left[{ }^{3} \mathrm{H}\right] \mathrm{CP}-55,940$, whereas a decrease in the binding affinity for the inverse agonist $\left[{ }^{3} \mathrm{H}\right] \mathrm{SR} 141716 \mathrm{~A}$ was observed (Price et al., 2005).

Distinct FFA1 receptor binding sites have been identified using the partial allosteric agonist $\left[{ }^{3} \mathrm{H}\right]$ AMG837 (position of the ${ }^{3} \mathrm{H}$ radioisotope was not reported) and the full allosteric agonist $\left[{ }^{3} \mathrm{H}\right] \mathrm{AM} 1638$ (Table 1) in experiments with and without endogenous FFA docosahexaenoic acid and other unlabeled FFA1 receptor agonists (Lin et al., 2012). Three allosterically linked binding sites were proposed, with the authors noting these ligand-receptor interactions were far more complex than previously recognized. These findings are important in the context of the role of FFA1 receptor in glucose-stimulated insulin secretion and may provide a novel multiligand treatment therapy for type 2 diabetes, in which a reduced dose of drug can be used due to ligand cooperativity. Another research group has reported the synthesis and use of $\left[{ }^{3} \mathrm{H}\right] \mathrm{TAK}-875$ (Fig. 1; Table 1) as a FFA1 receptor radioligand agonist (Bertrand et al., 2016a), based on the TAK-875 drug that failed Phase II clinical trials. After demonstrating that $\left[{ }^{3} \mathrm{H}\right] \mathrm{TAK}-875$ bound to GPR40-human embryonic kidney (HEK) cells in higher levels than in wild-type HEK cells, the research team developed a $\left[{ }^{18} \mathrm{~F}\right] \mathrm{TAK}-875$ radioligand (Radioligands for In Vivo Experiments).

The first reported radioligand-binding assay for FFA2 receptor used $\left[{ }^{3} \mathrm{H}\right] \mathrm{GLPG0974}$ (Table 1; position of the ${ }^{3} \mathrm{H}$ radioisotope not reported) as the competing ligand (Sergeev et al., 2016). This radiolabeled antagonist was characterized using saturation equilibriumbinding assays across several different FFA2 receptor mutants and then analyzed in kinetic binding assays, in particular to determine on and off rates of unlabeled agonists and antagonists. Data from these experiments led to the suggestion that an agonist requires interaction with both arginine residues (Arg-180 $0^{5.39}$ and Arg- $255^{7.35}$ ), whereas, for an antagonist, interaction with only one of these two arginines is required. This provided valuable information to aid rational structurebased design of novel tools and drugs for this therapeutically relevant receptor. Radioligands based on synthetic, selective scaffolds for FFA3 and FFA4 receptors have not yet been reported; however, researchers 
have used labeled fatty acids such as $\left[{ }^{33} \mathrm{P}\right] \mathrm{S} 1 \mathrm{P}$ to probe the binding site(s) of unlabeled synthetic agonists (Jo et al., 2012).

To eventually develop iodinated derivatives for in vivo imaging of $\mathrm{S} 1 \mathrm{P}$ receptor (Radioligands for in vivo experiments), Briard et al. (2015) made two radioligands- $\left[{ }^{14} \mathrm{C}\right] \mathrm{BAF} 312$ and a cold iodinated derivative of this $\left[{ }^{14} \mathrm{C}\right] 18$ (Fig. 1; Table 1) (Briard et al., 2015). These two ligands were used in autoradiography studies to compare biodistribution of the MS drug BAF312 (Fig. 1) to the iodinated derivative $\left[{ }^{127} \mathrm{I}\right]$ MS565 with the goal of making $\left[{ }^{123} \mathrm{I}\right] \mathrm{MS} 565$. Wholebody autoradiography studies in rats revealed similar biodistribution profiles of $\left[{ }^{14} \mathrm{C}\right] \mathrm{BAF} 312$ and $\left[{ }^{14} \mathrm{C}\right] 18$.

Radioligands based on synthetic LPA receptor ligands are not yet reported despite the availability of several high-affinity synthetic ligands for these receptors (Ohta et al., 2003; Qian et al., 2012). It is expected that development of radioligands based on synthetic ligands for studying LPA receptors will see rapid growth. This development will be fueled by the need to prepare novel ligands targeting these receptors for various disease conditions.

Selective synthetic radioligands are available for prostanoid family $\mathrm{DP}_{1}, \mathrm{DP}_{2}, \mathrm{FP}$, and TP receptors. The selective $\mathrm{DP}_{1}$ receptor antagonist $\left[{ }^{3} \mathrm{H}\right] \mathrm{BWA} 868 \mathrm{C}$ (Table 1) has been used for autoradiographic studies in human eye sections (Sharif et al., 2000). This study revealed high levels of $\mathrm{DP}_{1}$ receptor expression in ciliary epithelium/processes, ciliary muscles, the iris, and the retinal choroid, which was similar to that observed previously using the endogenous ligand $\left[{ }^{3} \mathrm{H}\right] \mathrm{PGD}_{2}$ (Matsuo and Cynader, 1993). Selective radiolabeled $\mathrm{DP}_{2}$ receptor antagonists have been reported: $\left[{ }^{3} \mathrm{H}\right] \mathrm{TRQ} 11238$ (Ulven et al., 2007), $\left[{ }^{3} \mathrm{H}_{3}\right]$ QAW039 (Luu et al., 2015), and $\left[{ }^{3} \mathrm{H}\right] \mathrm{OC}-$ 459 (Sykes et al., 2016) (Fig. 1; Table 1). Consideration of ligand-receptor kinetics is crucial in a drug discovery program, and often drug dissociation time from the receptor is clinically relevant. Sykes et al. (2016) therefore used $\left[{ }^{3} \mathrm{H}_{3}\right]$ QAW039 and $\left[{ }^{3} \mathrm{H}\right] \mathrm{OC}-459$ (tritiated versions of the Phase III asthma treatments fevipiprant and timapiprant, respectively) to directly measure drug kinetics and function in parallel to unravel the drug mechanism of action, concluding that QAW039 should competitively inhibit diseaserelevant $\mathrm{DP}_{2}$ receptor-mediated responses in human cells (Sykes et al., 2016).

Sharif et al. (1999) used the selective FP receptor agonist $\left[{ }^{3} \mathrm{H}\right] 9 \beta$-(+)-fluprostenol (Fig. 1 ; Table 1 ), a carboxylic acid derivative of the glaucoma drug travoprost, to study prostanoid receptor distribution in the human eye (Sharif et al., 1999), which revealed FP receptor distribution consistent with that obtained using tritiumlabeled endogenous ligand $\left[{ }^{3} \mathrm{H}\right] \mathrm{PGF}_{2 \alpha}$ (Matsuo and Cynader, 1992; Davis and Sharif, 1999).

$\left[{ }^{3} \mathrm{H}\right]$ Iloprost (Fig. 1; Table 1), the tritiated analog of the marketed agonist drug iloprost, has been used to investigate IP receptor expression and function, although it also possesses modest potency for $\mathrm{EP}_{3}$ and $\mathrm{EP}_{1}$ receptors (Abramovitz et al., 2000). Decreased saturation binding of $\left[{ }^{3} \mathrm{H}\right]$ iloprost in platelets of humans with type 2 diabetes compared with healthy humans has been demonstrated (Knebel et al., 2015). This finding along with other functional measurements led the authors to suggest that this lower IP receptor expression in platelets of patients with type 2 diabetes might lead to increased platelet aggregation, which may be the reason for the increased risk of thrombosis observed in such patients.

Among prostanoid receptors, the greatest number of radioligands has been developed to study TP receptor (Fig. 1; Table 1), probably due to its importance in thrombosis and related cardiovascular disorders. Selective antagonist $\left[{ }^{3} \mathrm{H}\right] \mathrm{SQ}-29548$ (Hanasaki et al., 1988; Hedberg et al., 1988) (Fig. 1; Table 1) is frequently used in competition-binding assays. For example, in one study, the antibody C-EL2Ab, which binds to the C-terminal of second extracellular loop of TP receptor, competitively inhibited the binding of $\left[{ }^{3} \mathrm{H}\right] \mathrm{SQ}-29548$ to TP receptor and also inhibited TP receptor-mediated platelet aggregation, which showed the importance of this portion of the receptor structure in platelet activation and the potential of C-EL2Ab as an alternative antiplatelet agent (Murad et al., 2012).

Compared with the prostanoid receptor family, there are far fewer synthetic scaffold-based radioligands reported for the leukotriene receptor family, and therefore radiolabeled endogenous ligands are frequently used. There is one report of the synthesis and use of the antagonist $\left[{ }^{3} \mathrm{H}\right] \mathrm{CGS} 23131$ (Fig. 1; Table 1) to characterize the single LTB4 receptor subtype recognized at that time on human polymorphonuclear neutrophils (Jackson et al., 1992) and several early reports on the use of $\left[{ }^{3} \mathrm{H}\right] \mathrm{ICI} 198615$ (Fig. 1; Table 1) (Aharony et al., 1988; O'Sullivan and Mong, 1989) to study the single recognized CysLT receptor. Pranlukast, a selective antagonist for $\mathrm{CysLT}_{1}$ receptor that is used clinically to treat asthma, has been tritium labeled and used for autoradiographic studies in human nasal inferior turbinates (Shirasaki et al., 2006). These studies revealed high distribution of $\mathrm{CysLT}_{1}$ receptor in vascular endothelium and the interstitial cells; however, the $K_{\mathrm{d}}$ of $\left[{ }^{3} \mathrm{H}\right]$ pranlukast was not reported.

There are many examples of synthetic high-affinity antagonists for PAF receptor, several of which have been radiolabeled and used as tools, for example $\left[{ }^{3} \mathrm{H}\right]-$ dihydrokadsurenone (Hwang et al., 1986), $\left[{ }^{3} \mathrm{H}\right] 52770-\mathrm{RP}$ (Robaut et al., 1987; Marquis et al., 1988), [ $\left.{ }^{3} \mathrm{H}\right]$ WEB2086 (also known as $\left[{ }^{3} \mathrm{H}\right]$ apafant) (Ukena et al., 1988), $\left[{ }^{3} \mathrm{H}\right] \mathrm{L}-$ 659989 (Hwang et al., 1989) (Fig. 1; Table 1), and $\left[{ }^{3} \mathrm{H}\right]$ SR27417 (Herbert, 1992) (Table 1). Determination of the degree of competition that a synthetic radioligand has with the endogenous receptor agonist is important; for example, it was shown that $\left[{ }^{3} \mathrm{H}\right] \mathrm{WEB} 2086$, but not 
$\left[{ }^{3} \mathrm{H}\right] 52770-\mathrm{RP}$, interacted with the same binding site as $\left[{ }^{3} \mathrm{H}\right] \mathrm{PAF}$ in human platelets (Ukena et al., 1988). Now commercially available, $\left[{ }^{3} \mathrm{H}\right] \mathrm{WEB} 2086$ has been used several times as a tool to study PAF receptor; for example, radioligand-binding assays showed that human B lymphoid cell line LA350 expressed high levels of PAF receptor (Zhuang et al., 2000). To date, synthetic radiolabeled ligands for GPBA receptor have not been reported; however, it is likely this will be an area of future interest as drugs targeting this receptor $(\mathrm{Xu}$, 2016) are developed.

2. Radioligands for In Vivo Experiments. In vivo radioligand experiments require consideration of blood brain barrier (BBB) permeability (if required) and ligand metabolism to radiometabolites that can complicate analysis. As discussed in Introduction, selectivity of a chemical tool in vivo requires careful consideration of receptor subtype selectivity (which is often first measured in vitro), versus relative in vivo expression levels of the subtypes/other receptors. Much effort has been directed toward the development of in vivo radioligands to study $\mathrm{CB}_{1}$ receptor in brain to investigate pain and addiction pathways. Despite PET radioisotopes having a shorter $\mathrm{t}_{1 / 2}\left({ }^{11} \mathrm{C} \mathrm{t}_{1 / 2}=20\right.$ minutes, ${ }^{18} \mathrm{~F}_{\mathrm{t} 1 / 2}=110$ minutes), Miller et al. (2008) compared with those used in SPECT $\left({ }^{123} \mathrm{I}\right.$ terminal $\mathrm{t}_{1 / 2}=13$ hours; $\gamma$ ray $\left.=159 \mathrm{keV}\right)$ (Kung et al., 2003). PET has been used extensively to study $\mathrm{CB}$ receptors due to higher resolution and sensitivity. A major challenge is that the short radioligand $t_{1 / 2}$ requires on demand synthesis with fast purification. PET and SPECT imaging time, which is also related to radioligand $t_{1 / 2}$, is usually insufficient to allow radioligand-receptor binding to reach equilibrium; therefore, appropriate kinetic models should be used to correct this. In vivo imaging of the ECB system using PET (Horti et al., 2014), brain imaging of CB receptors using PET and SPECT (Casteels et al., 2013), and synthesis of such radioligands (Ahamed et al., 2013) have recently been extensively reviewed. Of note and described in these reviews are radioligands $\left[{ }^{11} \mathrm{C}\right] \mathrm{OMAR}$, $\left[{ }^{11} \mathrm{C}\right] \mathrm{MePPEP},\left[{ }^{18} \mathrm{~F}\right] \mathrm{FMPEP}-d 2$, and $\left[{ }^{18} \mathrm{~F}\right] \mathrm{MK}-9470$, which have been used in preclinical imaging of CB receptors in humans. Since the publication of these reviews, additional novel radioligands have been reported and are discussed in this work along with more recent applications of commonly used in vivo radioligands.

$\left[{ }^{11}\right.$ C]OMAR (Table 2) is a structural analog of SR141716A (Fig. 1), in which a methyl and chlorine of SR141716A have been replaced with cyano and ${ }^{11} \mathrm{C}$ labeled methoxy to increase polarity (Fan et al., 2006). $\left[{ }^{11} \mathrm{C}\right] \mathrm{OMAR}$ has been used in human PET studies to characterize $\mathrm{hCB}_{1}$ receptor expression in cannabis dependence (D'Souza et al., 2016), post-traumatic stress disorder (Neumeister et al., 2013), and threat perception in trauma (Pietrzak et al., 2014). $\left[{ }^{18} \mathrm{~F}\right] \mathrm{MK}-9470$ (Table 2) is a high-affinity inverse agonist for $\mathrm{CB}_{1}$ receptor (Burns et al., 2007), which to date is the most widely used radioligand for in vivo $\mathrm{CB}_{1}$ receptor studies. Since the area was last reviewed (Horti et al., 2014), $\left[{ }^{18} \mathrm{~F}\right] \mathrm{MK}-9470$ has been used in PET experiments to analyze $\mathrm{hCB}_{1}$ receptor expression in schizophrenia (Ceccarini et al., 2013), prostate carcinoma (Emonds et al., 2013), Alzheimer's disease (Ahmad et al., 2014), alcohol dependence (Ceccarini et al., 2014), cannabis dependence (Ceccarini et al., 2015), functional dyspepsia (Ly et al., 2015), food intake disorders (Ceccarini et al., 2016b), and Huntington's disease (Ceccarini et al., 2016a).

The $\mathrm{CB}_{2}$ receptor in vivo radioligand toolbox is underdeveloped compared with that of $\mathrm{CB}_{1}$ receptor, perhaps due to the timeline of receptor subtype characterization and the intense interest in CNS-expressed $\mathrm{CB}_{1}$ receptor. The 2-oxoquinoline-based $\left[{ }^{11} \mathrm{C}\right] \mathrm{NE} 40$ (Table 2) (Evens et al., 2009) was the first radioligand used for in vivo PET imaging of $\mathrm{hCB}_{2}$ receptor (Ahmad et al., 2013) and will be an important tool for studying $\mathrm{CB}_{2}$ receptor in pathologic conditions. Ahmad et al. (2013) showed rapid brain uptake and washout of $\left[{ }^{11} \mathrm{C}\right]$ NE40, along with major uptake in lymphoid tissue in agreement with known expression of $\mathrm{hCB}_{2}$ receptor.

Hortala et al. (2014) developed a triazine-based radioligand $\left[{ }^{18} \mathrm{~F}\right] \mathrm{d}_{2}-3$ (Fig. 2; Table 2), which was used for PET imaging of $\mathrm{CB}_{2}$ receptor in rhesus monkey and baboon models of neuroinflammation (Hortala et al., 2014). $\left[{ }^{18} \mathrm{~F}\right] 5$ (Fig. 2; Table 2) is another triazine-based radioligand, which was developed to study in vivo distribution of a series of triazine-based $\mathrm{CB}_{2}$ receptor agonists (Yrjölä et al., 2015). Other radioligands with an oxoquinoline scaffold have been reported and used for imaging $\mathrm{CB}_{2}$ receptor in rats and mice, for example, $\left.{ }^{[1} \mathrm{C}\right] \mathrm{KD} 2$ (Mu et al., 2013), $\left.{ }^{[1} \mathrm{C}\right] \mathrm{RSR}-056$ (Slavik et al., 2015a), [ $\left.{ }^{11} \mathrm{C}\right] \mathrm{RS}-016$ (Slavik et al., 2015b), $\left[{ }^{18} \mathrm{~F}\right] \mathrm{RS}-126$ (Slavik et al., 2016), and $\left[{ }^{11} \mathrm{C}\right] \mathrm{KP} 23$ (Mu et al., 2014) (Fig. 2; Table 2). These oxoquinoline-based radioligands all exhibited similar patterns of biodistribution with high specific binding to spleen (concluded from excess cold ligand-blocking experiments) and low brain uptake, along with high nonspecific binding to liver and small intestine. It is unclear whether low brain uptake is solely a reflection of proportionally lower $\mathrm{CB}_{2}$ receptor expression in brain compared with spleen or also a function of poor BBB passage. In the case of $\left[{ }^{11} \mathrm{C}\right] \mathrm{RSR}$ 056 and $\left[{ }^{11} \mathrm{C}\right] \mathrm{RS}-016$, an increase in brain radioligand uptake in a neuroinflammatory mice model was observed as compared with healthy mice. However, it remains ambiguous whether this increase is a result of the increased expression of $\mathrm{CB}_{2}$ receptor or a result of increased brain permeability due to inflammation-induced disruption of the BBB.

Both cis and trans isomers of the naphthyridin-based radioligand $\left[{ }^{18} \mathrm{~F}\right] \mathrm{CB} 91$ were evaluated (Fig. 2; Table 2) with the cis/trans mixture then used for imaging $\mathrm{CB}_{2}$ receptor in mice and showed distribution in spleen and gut, consistent with known $\mathrm{CB}_{2}$ receptor distribution, 
but also in kidneys, pancreas, and brown adipose tissue. High liver accumulation of radioligand indicated rapid clearance by the hepatobiliary route (Saccomanni et al., 2015). $\left[{ }^{11}\right.$ C]AZD1940 (Fig. 2; Table 2) is a radiolabeled analog of a peripherally restricted CB receptor agonist AZD1940, which was a drug investigated for treatment of neuropathic pain. $\left[{ }^{11} \mathrm{C}\right] \mathrm{AZD} 1940$ was used for PET studies in monkeys to study the distribution of AZD1940 and revealed low CNS exposure; however, further experiments are required to determine the contribution of unbound versus $\mathrm{CB}$ receptor-bound ligand in brain given the nanomolar $\mathrm{CB}_{1}$ receptor affinity of $\left[{ }^{11} \mathrm{C}\right] \mathrm{AZD} 1940$ (Schou et al., 2013). Synthesis of PET radioligands based on aminoalkyl indole (Gao et al., 2014a) and benzenesulfonamide (Gao et al., 2014b) scaffolds has been reported; however, biologic data for these ligands are not yet reported. Most reported $\mathrm{CB}_{2}$ receptor radioligands exhibit high lipophilicity and metabolic susceptibility or lack $\mathrm{CB}_{2}$ receptor specificity, and much work still needs to be

TABLE 2

Commonly used and new CB receptor radioligands for in vivo use reported since (Casteels et al., 2013; Horti et al., 2014); FFA, S1P, prostanoid, leukotriene, and PAF receptor radioligands for in vivo use

\begin{tabular}{|c|c|c|c|}
\hline Tool & Data for Corresponding Cold Ligand & Function & Reference \\
\hline \multicolumn{4}{|c|}{$\mathrm{CB}_{1}$ Receptor-Selective Ligands } \\
\hline$\left[{ }^{11} \mathrm{C}\right] \mathrm{OMAR}$ & $\mathrm{hCB}_{1} K_{\mathrm{i}}=11 \pm 7 \mathrm{nM}$ & Inverse agonist & Fan et al., 2006 \\
\hline$\left[{ }^{18} \mathrm{~F}\right] \mathrm{MK}-9470$ & $\begin{array}{l}\mathrm{hCB}_{1} \mathrm{IC}_{50}=0.7 \mathrm{nM} \\
\mathrm{hCB}_{2} \mathrm{IC}_{50}=44 \mathrm{nM}\end{array}$ & Inverse agonist & Burns et al., 2007 \\
\hline \multicolumn{4}{|c|}{$\mathrm{CB}_{2}$ Receptor-Selective Ligands } \\
\hline$\left[{ }^{11} \mathrm{C}\right] \mathrm{NE} 40$ & $\mathrm{hCB}_{1} K_{\mathrm{i}}>1000 \mathrm{nM}$ & & Evens et al., 2009 \\
\hline & $\mathrm{hCB}_{2} K_{\mathrm{i}}=9.6 \mathrm{nM}$ & Inverse agonist & \\
\hline$\left[{ }^{18} \mathrm{~F}\right]-\mathrm{d}_{2}-3$ & $\mathrm{hCB}_{1} \mathrm{IC}_{50}=180 \mathrm{nM}$ & & Hortala et al., 2014 \\
\hline & $\mathrm{hCB}_{2} \mathrm{IC}_{50}=1.4 \mathrm{nM}$ & Agonist & \\
\hline$\left[{ }^{18} \mathrm{~F}\right] 5$ & $\mathrm{hCB}_{2} \mathrm{EC}_{50}=18.0-62.0 \mathrm{nM}$ & Agonist & Yrjölä et al., 2015 \\
\hline$\left[{ }^{11} \mathrm{C}\right] \mathrm{KD} 2$ & $\begin{array}{l}\mathrm{hCB}_{1} K_{\mathrm{i}}>10,000 \mathrm{nM} \\
\mathrm{hCB}_{2} K_{\mathrm{i}}=1.7 \pm 2.0 \mathrm{nM}\end{array}$ & Not determined & Mu et al., 2013 \\
\hline$\left[{ }^{11} \mathrm{C}\right] \mathrm{KP} 23$ & $\begin{array}{l}\mathrm{hCB}_{1} K_{\mathrm{i}}>1000 \mathrm{nM} \\
\mathrm{hCB}_{2} K_{\mathrm{i}}=6.8 \pm 5.8 \mathrm{nM}\end{array}$ & Not determined & Mu et al., 2014 \\
\hline$\left[{ }^{11} \mathrm{C}\right] \mathrm{RSR}-056$ & $\mathrm{hCB}_{2} K_{\mathrm{i}}=2.5 \mathrm{nM}$ & Not determined & Slavik et al., $2015 a$ \\
\hline$\left[{ }^{11} \mathrm{C}\right] \mathrm{RS}-016$ & $\begin{array}{l}\mathrm{hCB}_{1} K_{\mathrm{i}}>10,000 \mathrm{nM} \\
\mathrm{hCB}_{2} K_{\mathrm{i}}=0.7 \pm 0.6 \mathrm{nM}\end{array}$ & Not determined & Slavik et al., $2015 \mathrm{~b}$ \\
\hline$\left[{ }^{18} \mathrm{~F}\right] \mathrm{RS}-126$ & $\begin{array}{l}\mathrm{hCB}_{1} K_{\mathrm{i}}>10,000 \mathrm{nM} \\
\mathrm{hCB}_{2} K_{\mathrm{i}}=1.2 \pm 0.8 \mathrm{nM}\end{array}$ & Not determined & Slavik et al., 2016 \\
\hline$\left[{ }^{18} \mathrm{~F}\right] \mathrm{CB} 91$ (trans isomer) & $\begin{array}{l}\mathrm{hCB}_{1} K_{\mathrm{i}}=300 \mathrm{nM} \\
\mathrm{hCB}_{2} K_{\mathrm{i}}=9.0 \mathrm{nM}\end{array}$ & Not determined & Manera et al., 2009 \\
\hline$\left[{ }^{18} \mathrm{~F}\right] \mathrm{CB} 91$ (cis isomer) & $\begin{array}{l}\mathrm{hCB}_{1} K_{\mathrm{i}}=200 \mathrm{nM} \\
\mathrm{hCB}_{2} K_{\mathrm{i}}=0.7 \mathrm{nM}\end{array}$ & Not determined & Manera et al., 2009 \\
\hline \multicolumn{4}{|c|}{ Nonselective CB Receptor Ligands } \\
\hline$\left[{ }^{11} \mathrm{C}\right] \mathrm{AZD} 1940$ & $\begin{array}{l}\mathrm{hCB}_{1} K_{\mathrm{i}}=11.75 \mathrm{nM} \\
\mathrm{hCB}_{2} K_{\mathrm{i}}=0.87 \mathrm{nM}\end{array}$ & Agonist & Schou et al., 2013 \\
\hline \multicolumn{4}{|l|}{ FFA Receptor Ligands } \\
\hline$\left[{ }^{18} \mathrm{~F}\right] \mathrm{TAK} 875$ & hFFA1 2.4-fold more potent than TAK875 & Agonist & Bertrand et al., 2016a \\
\hline \multicolumn{4}{|l|}{ S1P Receptor Rigands } \\
\hline$\left[{ }^{18} \mathrm{~F}\right] 17$ & $\mathrm{hS}_{1} \mathrm{P}_{1 \%}$ Activity $^{a}=95$ & Agonist & Shaikh et al., 2015 \\
\hline$\left[{ }^{11} \mathrm{C}\right] \mathrm{TZ} 3321$ & $\begin{array}{l}\mathrm{hS} \mathrm{P}_{1} \mathrm{IC}_{50}=2.13 \pm 1.63 \mathrm{nM} \\
\mathrm{hS} \mathrm{P}_{2} \mathrm{IC}_{50}>1000 \mathrm{nM} \\
\mathrm{hS} \mathrm{IP}_{3} \mathrm{IC}_{50}>1000 \mathrm{nM}\end{array}$ & Not determined & Jin et al., 2017 \\
\hline$\left[{ }^{18} \mathrm{~F}\right] 28 \mathrm{c}$ & $\begin{array}{l}\mathrm{hS} \mathrm{P}_{1} \mathrm{IC}_{50}=2.63 \pm 0.27 \mathrm{nM} \\
\mathrm{hS} \mathrm{P}_{2} \mathrm{IC}_{50}>1000 \mathrm{nM} \\
\mathrm{hS} \mathrm{P}_{3} \mathrm{IC}_{50}>1000 \mathrm{nM}\end{array}$ & Not determined & Rosenberg et al., 2016 \\
\hline$\left[{ }^{11} \mathrm{C}\right] 5 \mathrm{a}$ & $\begin{array}{l}\mathrm{hS} \mathrm{P}_{1} \mathrm{IC}_{50}>1000 \mathrm{nM} \\
\mathrm{hS} \mathrm{P}_{2} \mathrm{IC}_{50}=9.52 \pm 0.70 \mathrm{nM} \\
\mathrm{hS} \mathrm{P}_{3} \mathrm{IC}_{50}>1000 \mathrm{nM}\end{array}$ & Not determined & Yue et al., 2015 \\
\hline \multicolumn{4}{|l|}{$\mathrm{DP}_{1}$ Receptor Ligands } \\
\hline $1-\left[{ }^{14} \mathrm{C}\right]$ & $\begin{array}{l}\mathrm{hDP}_{1} K_{\mathrm{i}}=1.5 \pm 0.57 \mathrm{nM} \\
\mathrm{hTP} K_{\mathrm{i}}=0.84 \pm 0.19 \mathrm{nM} \\
\mathrm{hEP}_{2} K_{\mathrm{i}}=410 \pm 320 \mathrm{nM} \\
\mathrm{hEP}_{3} K_{\mathrm{i}}=470 \pm 46 \mathrm{nM} \\
\mathrm{hIP} K_{\mathrm{i}}=400 \pm 100 \mathrm{nM}\end{array}$ & Antagonist & Sturino et al., 2007 \\
\hline $2-\left[{ }^{14} \mathrm{C}\right]$ & $\begin{array}{l}\mathrm{hDP}_{1} K_{\mathrm{i}}=1.1 \pm 0.22 \mathrm{nM} \\
\mathrm{hTP}_{\mathrm{i}}=14 \pm 2.7 \mathrm{nM} \\
\mathrm{hEP}_{2} K_{\mathrm{i}}=310 \pm 82 \mathrm{nM}\end{array}$ & Antagonist & Sturino et al., 2007 \\
\hline \multicolumn{4}{|l|}{$\mathrm{LTB}_{1}$ Receptor Ligands } \\
\hline SG380 & $\mathrm{LTB}_{1} \mathrm{IC}_{50}=18 \mathrm{nM}$ & Antagonist & Harris, 2008 \\
\hline \multicolumn{4}{|l|}{ PAF Receptor Ligands } \\
\hline$\left[{ }^{14} \mathrm{C}\right] \mathrm{WEB} 2086$ & $\mathrm{hPAF} K_{\mathrm{i}}=30 \pm 2.1 \mathrm{nM}$ & Antagonist & Parent et al., 1996 \\
\hline$\left[{ }^{14} \mathrm{C}\right] \mathrm{E} 6123$ & $\mathrm{hPAF} K_{\mathrm{i}}=2.7 \mathrm{nM}$ & Antagonist & Tsunoda et al., 1990; Sakuma et al., 1991 \\
\hline
\end{tabular}

${ }^{a}$ Percentage of activity is percentage reduction in peripheral blood $\mathrm{CD}^{+}$cells mediated by $\mathrm{S}_{1} \mathrm{P}_{1}$ receptor in mice treated with ligand as compared with control (untreated) mice. 
done to enable intricate in vivo imaging of $\mathrm{CB}_{2}$ receptor in humans.

As already discussed, there are very few reported FFA receptor radioligands. In the same body of work as $\left[{ }^{3} \mathrm{H}\right] \mathrm{TAK}-875$ (Radioligands for In Vitro Experiments), Bertrand et al. (2016a) also reported the synthesis of $\left[{ }^{18} \mathrm{~F}\right]$ TAK-875 (Fig. 3; Table 2). The cold analog $\left[{ }^{19} \mathrm{~F}\right]$ TAK-875 was also synthesized and showed similar FFA1 receptor agonist activity to TAK-875 (Fig. 1), and in vitro and in vivo studies are underway.

There are a greater number of in vivo radioligands for S1P compared with FFA and LPA receptors, a trend perhaps reflective of the number of marketed and under development drugs for $\mathrm{S} 1 \mathrm{P}$ receptor. The synthesis and evaluation of FTY720 analogs with a cold ${ }^{127}$ I appended to varying positions as a lead-in to making $\left[{ }^{123} \mathrm{I}\right]$ or $\left[{ }^{124} \mathrm{I}\right]$ radioligands for SPECT or PET S1P receptor imaging have been reported (Briard et al., 2011). The 2-iodo derivative, BZM055, was identified as a lead candidate for radiolabeling, and the authors comment that imaging studies are ongoing. Briard et al. (2015) also took a similar approach and synthesized an iodinated analog of the S1P receptor ligand BAF312 (Fig. 1). Distribution of cold analog $\left[{ }^{127} \mathrm{I}\right] \mathrm{MS} 565$ was analyzed using the equivalent $\left[{ }^{14} \mathrm{C}\right] 18$ tool (Radioligands for In Vitro Experiments) and is suitable for development of hot $\left[{ }^{123} \mathrm{I}\right] \mathrm{MS} 565$ as a SPECT tool (Briard et al., 2015).

Cold fluorinated derivatives of the $\mathrm{S}_{1} \mathrm{P}_{1}$ receptor antagonist W146 have been synthesized, with the most promising in vitro derivative radiolabeled to $\left[{ }^{18} \mathrm{~F}\right] 24$ (Fig. 3; binding affinity not reported) (Prasad et al., 2014). Although stable in serum, in vivo PET imaging of $\mathrm{S}_{1} \mathrm{P}_{1}$ receptor in mice using $\left[{ }^{18} \mathrm{~F}\right] 24$ showed accumulation of radioactivity in bone, most likely due to metabolic defluorination, thus limiting its use. The same laboratory subsequently reported $\left[{ }^{18} \mathrm{~F}\right] 17$, a derivative of FTY720, for imaging S1P receptors (Fig. 3; Table 2) (Shaikh et al., 2015). $\left[{ }^{18} \mathrm{~F}\right] 17$ induced peripheral blood lymphopenia (a measure of $\mathrm{S}_{1} \mathrm{P}_{1}$ receptor downstream regulation) at a comparable level to FTY720 and did not undergo defluorination during mice PET studies; however, rapid clearance of $\left[{ }^{18} \mathrm{~F}\right] 17$ was observed. Thus, further optimization of these PET radioligands is required.

$\left[{ }^{11} \mathrm{C}\right]$ TZ3321 (Fig. 3; Table 2), based on a selective $\mathrm{S}_{1} \mathrm{P}_{1}$ receptor oxadiazole scaffold, has been reported and used in MicroPET imaging studies in a femoral artery wire-injury mouse model (Jin et al., 2017). These studies revealed high expression of $\mathrm{S}_{1} \mathrm{P}_{1}$ receptor, in line with the proposal that higher levels of this receptor are observed in vascular smooth muscle cells following intimal lesions usually caused by in-stent restenosis. The same research group then reported synthesis of the PET radioligand $\left[{ }^{18} \mathrm{~F}\right] 28 \mathrm{c}$ (Fig. 3; Table 2), also based on oxadiazole scaffold (Rosenberg et al., 2016). ${\mathrm{S} 1 \mathrm{P}_{1}}_{1}$ receptor expression is thought to increase in inflammation, and in vivo PET imaging indeed showed increased
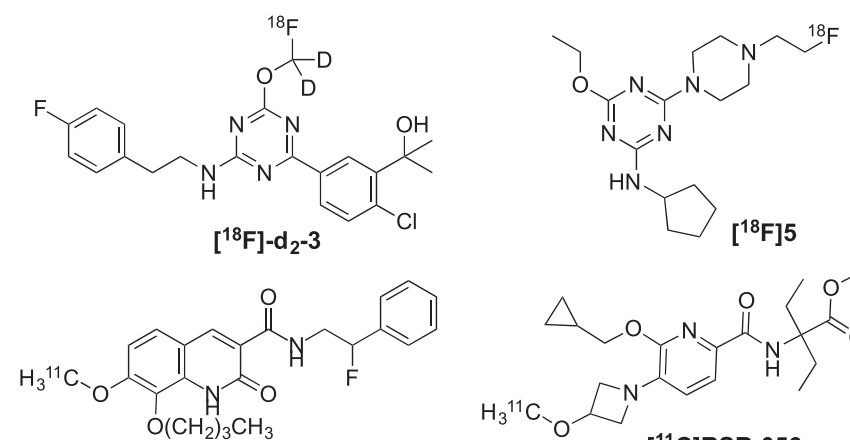

$\left[{ }^{11} \mathrm{C}\right] \mathrm{KP} 23$

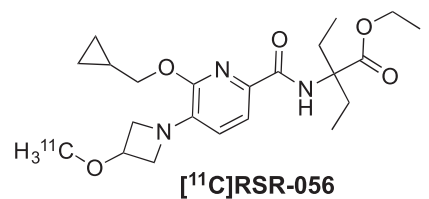

$\left[{ }^{11} \mathrm{C}\right]$ RSR-056

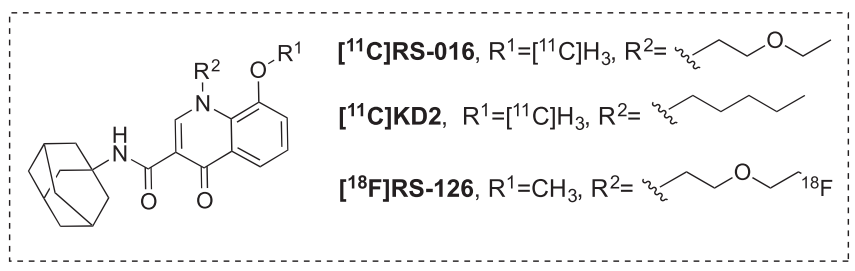

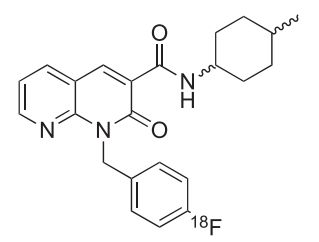

$\left[{ }^{18} \mathrm{~F}\right] \mathrm{CB} 91$, cis and trans

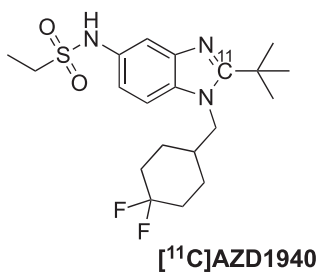

[11C]AZD1940
Fig. 2. CB receptor radioligand tools for in vivo studies reported since (Casteels et al., 2013; Horti et al., 2014). Note: structures are not shown for radioligands with unknown radioisotope position.

binding of $\left[{ }^{18} \mathrm{~F}\right] 28 \mathrm{c}$ in the liver of lipopolysaccharidetreated mice compared with control mice. This radioligand could be an important tool for monitoring $\mathrm{S}_{1} \mathrm{P}_{1}$ receptor expression as a measure of inflammation.

Radioligand tools have been developed for imaging $\mathrm{S} \mathrm{P}_{2}$ receptor, for example, $\left[{ }^{11} \mathrm{C}\right] 5 \mathrm{a}$ (Fig. 3 ; Table 2) (Yue et al., 2015), which is a derivative of the $\mathrm{S}_{1} \mathrm{P}_{2}$ receptor antagonist JTE-013. PET studies in mice showed high uptake of $\left[{ }^{11} \mathrm{C}\right] 5 \mathrm{a}$ in $\mathrm{S}_{1} \mathrm{P}_{2}$ receptor-rich regions such as heart, lung, kidney, and liver. Low brain levels were observed, with the authors suggesting that this could be due to radioligand efflux by $\mathrm{P}$-glycoprotein (P-gp), as an increase in brain penetrability was observed on treatment with P-gp inhibitor cyclosporine A. Further improvements in brain uptake of this radioligand are required before utility in PET imaging of MS and neuroinflammation conditions is achieved. $\mathrm{S} \mathrm{P}_{3}$ receptor radioligands have also been developed for in vivo imaging. $\left[{ }^{18} \mathrm{~F}\right] 1$, a mixture of two compounds (Fig. 3), was synthesized based on a known $\left[{ }^{19} \mathrm{~F}\right]$-containing indole-based ligand for $\mathrm{S}_{3} \mathrm{P}_{3}$ receptor (Rokka et al., 2013); however, to date pharmacological data for this radioligand have not been reported.

Four $\left[{ }^{14} \mathrm{C}\right]$-labeled DP receptor antagonists, including 1- $\left[{ }^{14} \mathrm{C}\right]$ and 2- $\left[{ }^{14} \mathrm{C}\right]$ (Fig. 3; Table 2) (Berthelette and Wang, 2007), along with three $\left[{ }^{3} \mathrm{H}\right]$-labeled analogs (Scheigetz et al., 2004), have been synthesized and used 
to study the extent of covalent protein labeling in vitro (Sturino et al., 2007). These $\left[{ }^{14} \mathrm{C}\right]$-labeled DP receptor antagonists may prove useful tools for in vivo DP receptor studies in the future, although DP receptor selectivity in particular over TP receptor will require further optimization. $\left[{ }^{14} \mathrm{C}\right]$-Fluprostenol has been used to analyze the disposition and metabolism of an intramuscular injection of fluprostenol in horses (Chapman et al., 1980), although DP receptors were not directly investigated.

An optimized [ [99m Tc]RP517-containing formulation has been developed as a [ $\left.{ }^{99 \mathrm{~m}} \mathrm{Tc}\right]$-labeled analog of the hydrazinonicotinamide-conjugated $\mathrm{LTB} 4_{1}$ receptor antagonist SG380 (Table 1; unchelated ligand) for imaging infection and inflammation (Liu et al., 2002). A study by Riou et al. (2002) examined [ $\left.{ }^{99 \mathrm{~m}} \mathrm{Tc}\right] \mathrm{RP5} 17$ uptake in an ischemia-reperfusion-induced myocardial inflammation model, and found that postreperfusion $\left[{ }^{99 \mathrm{~m}} \mathrm{Tc}\right]$ RP517 uptake correlated with myeloperoxidase (a specific neutrophil enzyme) levels. Ex vivo imaging of heart slices postreperfusion also showed [ ${ }^{99 \mathrm{~m} T c] R P 517}$ localized within the area of inflammation. To investigate whether these results might be $\mathrm{LTB} 4_{1}$ receptor specific, Riou et al. (2002) also performed in vitro studies using [F]-RP517, an undisclosed CY3 fluorescently tagged analog of RP517, which showed a $44 \%$ displacement with $\mathrm{LTB}_{4}$ and complete displacement with nonfluorescent RP517 on isolated neutrophils. [ ${ }^{99 \mathrm{~m}}$ Tc]RP517 has also been used as a tool to study Escherichia coli infection in rabbits; however, although accumulation of $\left[{ }^{99 \mathrm{~m}} \mathrm{Tc}\right] \mathrm{RP} 517$ occurred in the abscess, there was also significant accumulation in the intestines, leading the authors to propose development of a more hydrophilic tool (Brouwers et al., 2000). This research group then reported ${ }^{111}$ In labeling of the more hydrophilic LTB4 1 receptor antagonist DPC11870-11 (Van Eerd et al., 2003). [ $\left.{ }^{111} \mathrm{In}\right]-\mathrm{DPC} 11870-11$ showed specific receptor interactions, localized to infection foci rapidly after injection and showed minimal accumulation in the intestines.

$\left[{ }^{14} \mathrm{C}\right]$ WEB2086 (also called $\left[{ }^{14} \mathrm{C}\right]$ apafant) (Table 2) was first reported in a patent in 1989 (Birke and Stiasni, 1989) and has since been used to show apafant is a substrate for P-gp but has not been used to directly interrogate PAF receptor (Leusch et al., 2002; Fuchs et al., 2014). Again, in a pharmacokinetic rather than direct PAF receptor study, $\left[{ }^{14} \mathrm{C}\right] \mathrm{E} 6123$ (Table 2) has been reported and used to probe metabolic enzymes of PAF antagonist E6123 (Kusano et al., 1993).

PET radioligands are valuable tools for studying the pharmacokinetics of investigational drugs and in vivo imaging of GPCRs. In particular, many in vivo radioligands have been reported for $\mathrm{CB}$ receptor, and it is anticipated in the near future more radioligands for the other class A lipid-binding GPCRs will be developed, thus facilitating an understanding of the role these receptors have in disease conditions.

\section{Small-Molecule Fluorescent Tools}

\section{A. Characteristics and Design Rationale}

Small-molecule-based fluorescent tools have been used to study molecular targets, such as receptors, enzymes, proteins, small molecules, and ion channels, and are increasingly being used to study GPCRs (Vernall et al., 2014; Stoddart et al., 2015). Other fluorescent-based techniques, such as yellow fluorescent protein and green fluorescent protein genetic tags, antibodies, nanoparticles, and tagged proteins (Cottet et al., 2013; Ciruela et al., 2014; Ma et al., 2014; Sridharan et al., 2014; Stoddart et al., 2016), are also used but are outside the scope of this review.

Small-molecule-based fluorescent tools are commonly synthesized by tethering a known pharmacophore/ligand to a fluorophore via a covalent linker. Pharmacophore selection is guided by target receptor affinity, selectivity, and the desired utility of the fluorescent ligand (antagonist, agonist, etc.). The linker is positioned in a benign area of the pharmacophore and is of an appropriate length such that the binding of the pharmacophore to the receptor is not perturbed. However, this is often based on experimental trial and error rather than on predictive comparable functionality to the parent pharmacophore. Fluorophore selection is dependent on choice of wavelength and equipment filter

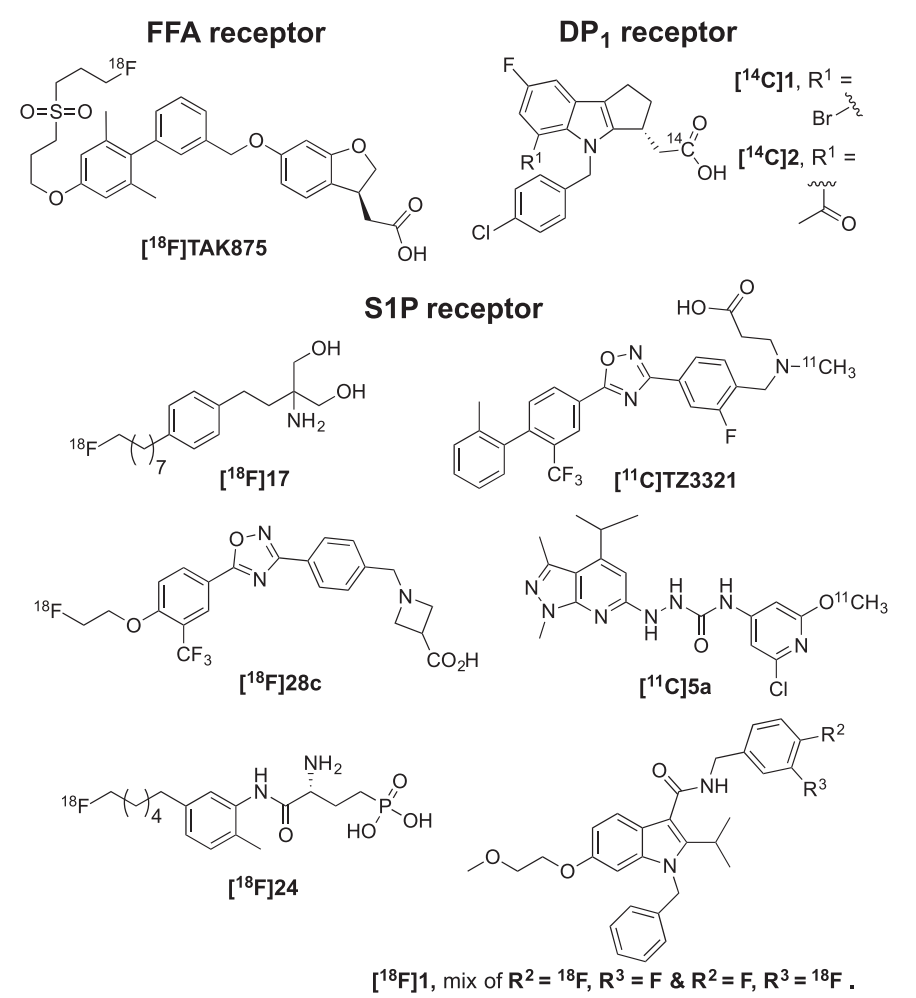

Fig. 3. FFA, S1P, and prostanoid receptor radioligand tools for in vivo studies. Note: structures are not shown for radioligands with unknown radioisotope position. The structures of [ $\left.{ }^{99 m} \mathrm{Tc}\right] \mathrm{RP} 517$ and $\left[{ }^{111} \mathrm{In}\right]-\mathrm{DPC} 11870-11$ are not shown because of size. 
path length, quantum yield, resistance to photo bleaching, and appropriate physicochemical properties. There are examples of a fluorophore designed as part of a pharmacophore (Fluorescent Tools for In Vitro Experiments) and a fluorophore acting as a biologically active ligand itself (May et al., 2010; Dale et al., 2012). Another design approach is to join a fluorophore to a suitably tagged ligand in situ during the biologic experiment (Fluorescent Tools for In Vitro Experiments). Much like radioligands, the physicochemical characteristics of a fluorescent tool must allow for specific receptor binding and minimal nonspecific interactions such as with the membrane, to obtain a high signal to noise ratio. This is especially challenging for receptors with endogenous lipid ligands and lipophilic synthetic ligands. To this end, the linker and fluorophore could be used to tune the overall physicochemical properties of fluorescent tools, although the proposed entry via a lipid portal into some of these receptors (Rational Design of Tools and Consideration for Use) must not be forgotten.

\section{B. Applications of Small-Molecule Fluorescent Tools}

The increasing availability of small-molecule fluorescent tools, both commercially and via published synthesis, is progressing the use of techniques such as fluorescence confocal microscopy, scanning confocal microscopy, flow cytometry, high-throughput screening, fluorescence correlation spectroscopy, fluorescence resonance energy transfer and BRET assays, and diagnostic imaging to study receptor pharmacology. Once a pharmacophore-linker-fluorophore ligand is successfully developed, it is a lead point for attachment of another entity in place of the fluorophore, for example, another pharmacophore for a bivalent ligand, a magnetic resonance-based ligand, or theranostic agent. Many of the reported fluorescent tools have not been fully pharmacologically characterized for functional activity, that is, agonist, antagonist, or inverse agonist, which can be an important consideration as the functionality and application of a fluorescent tool are often different from the parent pharmacophore.

1. Fluorescent Tools for In Vitro Experiments. Early reports of fluorescent small molecules for lipidbinding GPCRs were of labeled endogenous receptor agonists, for example, a benzoxadiazole-based fluorophore linked to anandamide (Koga et al., 1995) or to S1P (Hakogi et al., 2003; Yamamoto et al., 2008). Bile acid derivatives have been linked to nitrobenzoxadiazole (NBD) fluorophores and used to study cellular uptake (Májer et al., 2012), and fluorescent LTB $_{4}$ linked to two AlexaFluor fluorophores has been used specifically to study LTB4 $4_{1}$ receptor (Sabirsh et al., 2005). An early report of a flow cytometry assay for FFA1 receptor used the commercially available fluorescent ligand C1-BODIPY-C12 (Hara et al., 2009). Many endogenous ligands for $\mathrm{CB}, \mathrm{FFA}$, and $\mathrm{S} 1 \mathrm{P}$ receptor are now commercially available attached to a range of fluorophores.

In 2008, a biotin-AEA tool was developed to study the biodistribution of AEA, which was visualized in a two-step process using an anti-biotin monoclonal antibody (mAb), followed by a green fluorescent anti-mouse secondary antibody (Fezza et al., 2008). Martin-Couce et al. (2011) described modification of the ECBs AEA, 2-AG, and 2-arachidonyl glyceryl ether (2-AGE) to contain a biotin or alkyne tag for subsequent direct, selective in situ fluorescent labeling with a streptavidin-fluorophore or a click reaction, respectively. The 2-AGE ECB tagged with an alkyne was the most potent tool, but it lacked receptor subtype selectivity $\left(K_{\mathrm{i}}=84.7 \pm 0.8 \mathrm{nM}\right.$ at $\mathrm{hCB}_{1}$; $84.9 \pm 0.6 \mathrm{nM}$ at hCB ${ }_{2}$, whereas 2-AGE-biotin-3b (Fig. 4; Table 3$)$ showed some selectivity $\left(K_{\mathrm{i}}=221 \pm 8 \mathrm{nM}\right.$ at $\mathrm{hCB}_{1}, 450 \pm 11 \mathrm{nM}$ at $\mathrm{hCB}_{2}$ ). Imaging of $\mathrm{hCB}_{1}$ receptor in mouse hippocampal cell lines (HT-22) transfected with $\mathrm{CB}_{1}$ receptor has been carried out by reaction of 2 -AGEbiotin-3b with streptavidin-Alexa488 fluorophore in situ. Some background fluorescence was observed in control experiments using either nontransfected cells or with a high concentration of the $\mathrm{CB}_{1}$ and $\mathrm{CB}_{2}$ receptor agonist HU210, indicating some nonspecific binding. The ligand 2-AGE and other ECBs are lipids, so using these as a basis for chemical tools means large amounts of nonspecific membrane binding are probable along with modest, if any, CB receptor subtype selectivity, driving the need for fluorescent, synthetic ligands with improved selectivity and physicochemical properties.

The first reported fluorescent tools based on a nonendogenous CB pharmacophore were dansyl derivatives of THC (Forrest et al., 1971), and these were used for analytical tracing of cannabinoid ligands (Just et al., 1972). However, as this was prior to CB receptor characterization, these fluorescent compounds were not evaluated explicitly as CB receptor ligands. About 30 years later, a fluorescent naphthoyl indole $\mathrm{CB}_{2}$ receptor agonist designed around JWH-015 was developed using a $\mathrm{CB}_{2}$ receptor homology model and ligand docking that indicated a naphthoyl-linker position may be tolerated and the NBD fluorophore could act as a second pharmacophore with the receptor (Yates et al., 2005). Unfortunately, this fluorescent compound had significant loss of affinity ( $10 \mu \mathrm{M}$ gave $25 \%$ displacement of $\left[{ }^{3} \mathrm{H}\right] \mathrm{CP}-55940$ from $\mathrm{CB}_{2}$ receptor) compared with parent indole agonist JWH-015, cytosolic accumulation, and nonspecific binding. In another report, replacement of part of an orthosteric pharmacophore with a fluorescent moiety has been reported to generate a fluorescent $\mathrm{CB}_{2}$ receptor tool (Petrov et al., 2011). The morpholine of isatin acylhydrazone, believed to interact with the lipophilic cavity of $\mathrm{CB}_{2}$ receptor, was substituted with NBD to provide the $\mathrm{CB}_{2}$ receptorselective NMP6 (Fig. 4; Table 3). Confocal microscopy demonstrated specific binding of NMP6 to $\mathrm{CB}_{2}$ receptor on $\mathrm{CD}^{+} \mathrm{T}$ cells, as binding was inhibited by 

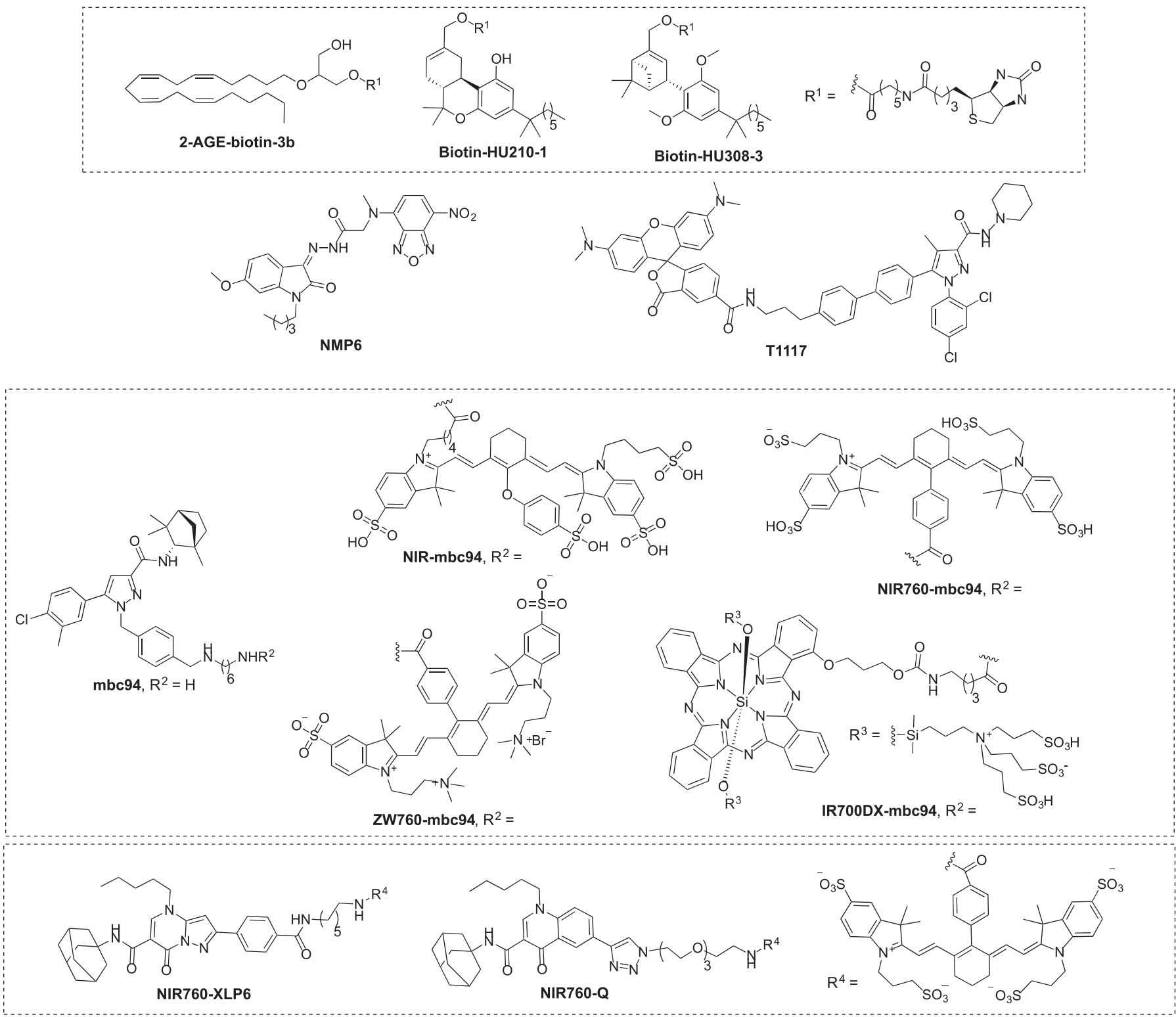

Fig. 4. CB receptor fluorescent tools.

preincubation with the selective $\mathrm{CB}_{2}$ receptor agonist GW842166X. Further utility of NMP6 was demonstrated using flow cytometry to study $\mathrm{CB}_{2}$ receptor expression on mouse lung mononuclear $\mathrm{B}$ cells.

Use of commercially available T1117 (tocrifluor 1117) (Fig. 4; Table 3) was first reported in 2008 (Daly et al., 2008). T1117 was developed by linking AM251 [a $\mathrm{CB}_{1}$ receptor-selective inverse agonist, $\mathrm{IC}_{50}=4 \pm 1 \mathrm{nM}$ (Gatley et al., 1997)] to a tetramethylrhodamine fluorophore. There are conflicting reports regarding pharmacological characterization-early studies reported T1117 to bind to GPR55 (increased $\mathrm{Ca}^{2+}$ response in HEK293 cells expressing GPR55) with only weak affinity at $\mathrm{CB}_{1}$ receptor (Daly et al., 2010). However, in a different study, T1117 exhibited moderate binding at $\mathrm{CB}_{1}$ receptor $\left(K_{\mathrm{d}}=\right.$ $460 \pm 80 \mathrm{nM}$ at $\mathrm{rCB} 1$ ) and was used in a $\mathrm{CB}_{1}$ receptor competition-binding assay (Bruno et al., 2014). The fluorescence of T1117 was quenched upon $\mathrm{CB}_{1}$ receptor binding and restored upon displacement by unlabeled test compounds. T1117 was then used as the competitive tracer in a binding assay, providing $\mathrm{IC}_{50}$ values for anandamide and AM251 in agreement with literature values. Bruno et al. (2014) further demonstrated utility of T1117 as a drug discovery tool by the appropriate identification of the $C_{1}$ receptor allosteric ligand ORG27569 (Fig. 6). However, use of T1117 to study $\mathrm{CB}_{1}$ receptor in native cell environments is limited, as it exhibits nonspecific binding to membrane most likely due to high lipophilicity (Bruno et al., 2014). This limitation is probe specific and not a general feature of fluorescent ligands, as demonstrated by fluorescent ligands for FFA1 receptor (discussed in this work) and for other class A GPCRs (reviewed in Vernall et al., 2014) that can be used to study GPCRs in native cell environments. 
TABLE 3

$\mathrm{CB}, \mathrm{FFA}$, and prostanoid receptor fluorescent ligands

\begin{tabular}{|c|c|c|}
\hline Tool & Data & Reference \\
\hline \multicolumn{3}{|l|}{$\mathrm{CB}_{1}$ Receptor and GPR55 Receptor Ligands } \\
\hline T1117 & $\begin{array}{l}\text { hGPR55-mediated } \mathrm{Ca}^{2+} \text { response in HEK293 cells } \\
\text { mCB }_{1} 10 \% \text { displacement of }\left[{ }^{3} \mathrm{H}\right] \mathrm{CP}-55,940 \text { with } 1 \mu \mathrm{M} \text { T1117 } \\
\mathrm{hCB}_{1} K_{\mathrm{d}}=460 \pm 80 \mathrm{nM}\end{array}$ & $\begin{array}{l}\text { Daly et al., } 2010 \\
\text { Bruno et al., } 2014\end{array}$ \\
\hline \multicolumn{3}{|l|}{ CB Receptor Ligands } \\
\hline 2-AGE-biotin-3b ${ }^{b}$ & $\begin{array}{l}\mathrm{hCB}_{1} K_{\mathrm{i}}=221 \pm 8 \mathrm{nM} \\
\mathrm{hCB}_{2} K_{\mathrm{i}}=450 \pm 11 \mathrm{nM}\end{array}$ & Martin-Couce et al., 2011 \\
\hline NMP6 & $\begin{array}{l}\mathrm{hCB}_{1}<40 \% \text { at } 10 \mu \mathrm{M} \\
\mathrm{hCB}_{2} K_{\mathrm{i}}=387 \mathrm{nM}\end{array}$ & Petrov et al., 2011 \\
\hline Biotin-HU210-1 ${ }^{a}$ & $\begin{array}{l}\mathrm{hCB}_{1} K_{\mathrm{i}}=2.4 \pm 0.4 \mathrm{nM} \\
\mathrm{hCB}_{2} K_{\mathrm{i}}=1.6 \pm 0.4 \mathrm{nM}\end{array}$ & Martín-Couce et al., 2011 \\
\hline Biotin-HU308-3 ${ }^{a}$ & $\begin{array}{l}\mathrm{hCB}_{1} K_{\mathrm{i}}>5000 \mathrm{nM} \\
\mathrm{hCB}_{2} K_{\mathrm{i}}=44 \pm 4 \mathrm{nM}\end{array}$ & Martín-Couce et al., 2011 \\
\hline NIR-mbc94 & $\mathrm{mCB}_{2} K \mathrm{i}=260 \mathrm{nM}$ & Sexton et al., 2011 \\
\hline NIR760-mbc94 & $\mathrm{mCB}_{2} K_{\mathrm{d}}=26.9 \pm 3.7 \mathrm{nM}$ & Zhang et al., 2013 \\
\hline NIR760-Q & $\mathrm{hCB}_{2} K_{\mathrm{d}}=75.51 \pm 27.97 \mathrm{nM}$ & Wu et al., 2014b \\
\hline ZW760-mbc94 & $\mathrm{mCB}_{2} K_{\mathrm{d}}=53.9 \pm 13.0 \mathrm{nM}$ & Wu et al., $2014 \mathrm{a}$ \\
\hline NIR760-XLP6 & $\begin{array}{l}\mathrm{mCB}_{1} K_{\mathrm{d}}>10,000 \mathrm{nM} \\
\mathrm{mCB}_{2} K_{\mathrm{d}}=169.1 \pm 66.09 \mathrm{nM}\end{array}$ & Ling et al., 2015 \\
\hline IR700DX-mbc94 & $\mathrm{mCB}_{2} K_{\mathrm{d}}=42.0 \pm 19.6 \mathrm{nM}$ & Zhang et al., 2014 \\
\hline \multicolumn{3}{|l|}{ FFA Receptor Ligands } \\
\hline $\begin{array}{l}\text { TUG-905-NBD-4 } \\
\text { F-TAK-875A } \\
\text { TAK-875-Alexa488-16 }\end{array}$ & $\begin{array}{l}\text { hFFA1 } K_{\mathrm{d}}=7.4 \pm 1.3 \mathrm{nM} \\
\text { hFFA1 } K_{\mathrm{d}}=15.1 \pm 3.2 \mathrm{nM} \\
\text { hFFA1-mediated } \mathrm{Ca}^{2+} \text { response equipotent to TAK- } 875\end{array}$ & $\begin{array}{l}\text { Christiansen et al., } 2016 \\
\text { Ren et al., } 2016 \\
\text { Bertrand et al., } 2016 \mathrm{~b}\end{array}$ \\
\hline \multicolumn{3}{|l|}{$\mathrm{EP}_{3}$ Receptor Ligands } \\
\hline Pyryllium-labeled cinnamon acid derivative 8 & $\begin{array}{l}\mathrm{hEP}_{1} \mathrm{Ki}=68,625 \pm 12,735 \mathrm{nM} \\
\mathrm{hEP}_{2} \mathrm{Ki}=2943 \pm 279 \mathrm{nM} \\
\mathrm{hEP}_{3} \mathrm{Ki}=135 \pm 23 \mathrm{nM} \\
\mathrm{hEP}_{4} \mathrm{Ki}=902 \pm 226 \mathrm{nM}\end{array}$ & Tomasch et al., 2012 \\
\hline
\end{tabular}

${ }^{a}$ HEK293 cells stably expressing GPR55.

${ }^{b}$ Biotin-tagged ligand (precursor for fluorescent tool) that conjugates with streptavidin-fluorophore in situ during the biologic experiment to provide corresponding fluorescent tool.

CB receptor agonists HU210 and HU308 were derivatized with a biotin tag at the ethoxy position, suitable for subsequent in situ conjugation to a fluorophore (Martín-Couce et al., 2012). The biotin-derivatized HU210-1 exhibited high affinity but little subtype selectivity for CB receptors, whereas biotin-derivatized HU3083 exhibited selectivity for $\mathrm{CB}_{2}$ receptor (Fig. 4; Table 3). Endogenous $\mathrm{CB}_{1}$ and $\mathrm{CB}_{2}$ receptor expression was studied in neurons and microglia using biotin-HU210-1 and biotinHU308-3 by addition of streptavidin-Alexa488 fluorophore, and receptor-specific binding was then confirmed by using unlabeled HU210. Martín-Couce et al. (2012) also used biotin-HU210-1 in flow cytometry to study CB receptor expression in the monocytic cell line THP-1 at the single-cell level. The same research group has used biotin-HU210-1 in conjugation with streptavidin-Alexa488 to show there is high $\mathrm{CB}_{1}$ receptor expression in $\mathrm{B}, \mathrm{T}$, plasmacytoid dendritic, and myeloid dendritic cells from donors with allergic rhinitis, atopic dermatitis, or food allergies (Martin-Fontecha et al., 2014).

Recently, within the space of a few months, there were three independent reports of fluorescent ligands for FFA1 receptor. In one of these reports, fluorescent ligands based on the TUG-770 or TUG-905 pharmacophore linked to a NBD fluorophore were constructed (Christiansen et al., 2016). Of these, TUG-905-NBD-4 (Fig. 5; Table 3) showed only a small reduction in potency compared with TUG-905 and retained FFA1 receptor agonism. A BRET assay paired with NanoLuciferase-tagged FFA1 receptor was established using TUG-905-NBD-4, with low levels of nonspecific fluorescence allowing for measurement of ligand kinetic parameters, and also a robust competitionbinding assay was established. In a different study, a fluorescein-conjugated TAK-875 (Fig. 1) ligand (F-TAK875A) (Fig. 5; Table 3) was synthesized as a racemic mixture and used in flow cytometry competition assays, which showed that FFA carbon-chain length was correlated with binding potency to FFA1 receptor (Ren et al., 2016). In the third report, Bertrand et al. (2016b) synthesized and evaluated a series of TAK-875-linkerfluorophore conjugates containing different types of linkers and fluorophores. In live cells overexpressing hFFA1 receptor, the lead probe TAK-875-Alexa488-16 (Fig. 5; Table 3) showed specific labeling of FFA1 receptor. This fluorescent agonist may prove especially valuable for studying dynamic receptor processes as 90 -minute postincubation fluorescent internalization was observed. Endogenously expressed FFA1 receptor in pancreatic $\beta$ cells was then visualized using a combination of TAK-875Alexa488-16 and an Alexa488 antibody to amplify the signal. These reports collectively highlight the importance of both linker position and physicochemical properties for a successful fluorescent imaging tool. All three of these reports were based on a FFA1 receptor-selective parent 
pharmacophore (TAK-875 or TUG-905 core); however, the affinity and/or function of the fluorescent tool at the other FFA receptors were not provided, and it can be predicted, but not assumed, that the fluorescent tool and parent pharmacophore have a comparable receptor subtype selectivity profile.

To our knowledge, the only report of high-affinity synthetic ligand fluorescent conjugates for prostanoid, leukotriene, PAF, or GBPA receptors is by Tomasch et al. (2012), who synthesized a series of cinnamic acid antagonists containing various fluorophores. The most promising fluorescent compound when accounting for both $\mathrm{EP}_{3}$ receptor affinity and a desirable emission wavelength above that of tissue autofluorescence was pyryllium-labeled cinnamon acid derivative 8 (Fig. 5; Table 3). Although with approximately threefold reduced affinity for $\mathrm{EP}_{3}$ receptor compared with the parent, nonfluorescent pharmacophore, in different cell lines with respective recombinant $\mathrm{EP}_{1-4}$ receptor subtypes, eight showed selectivity for $\mathrm{EP}_{3}$ receptor over $\mathrm{EP}_{1}$ (550-fold), $\mathrm{EP}_{2}$ (24-fold), and $\mathrm{EP}_{4}$ receptor (sevenfold). Labeling of $\mathrm{EP}_{3}$ receptors in HT-29 cells using eight was demonstrated, with binding determined as specific by displacement of eight with excess nonfluorescent selective $\mathrm{EP}_{3}$ receptor ligand. Further utility of eight was demonstrated in murine kidney, human brain tissue, and human platelets, with the authors commenting that
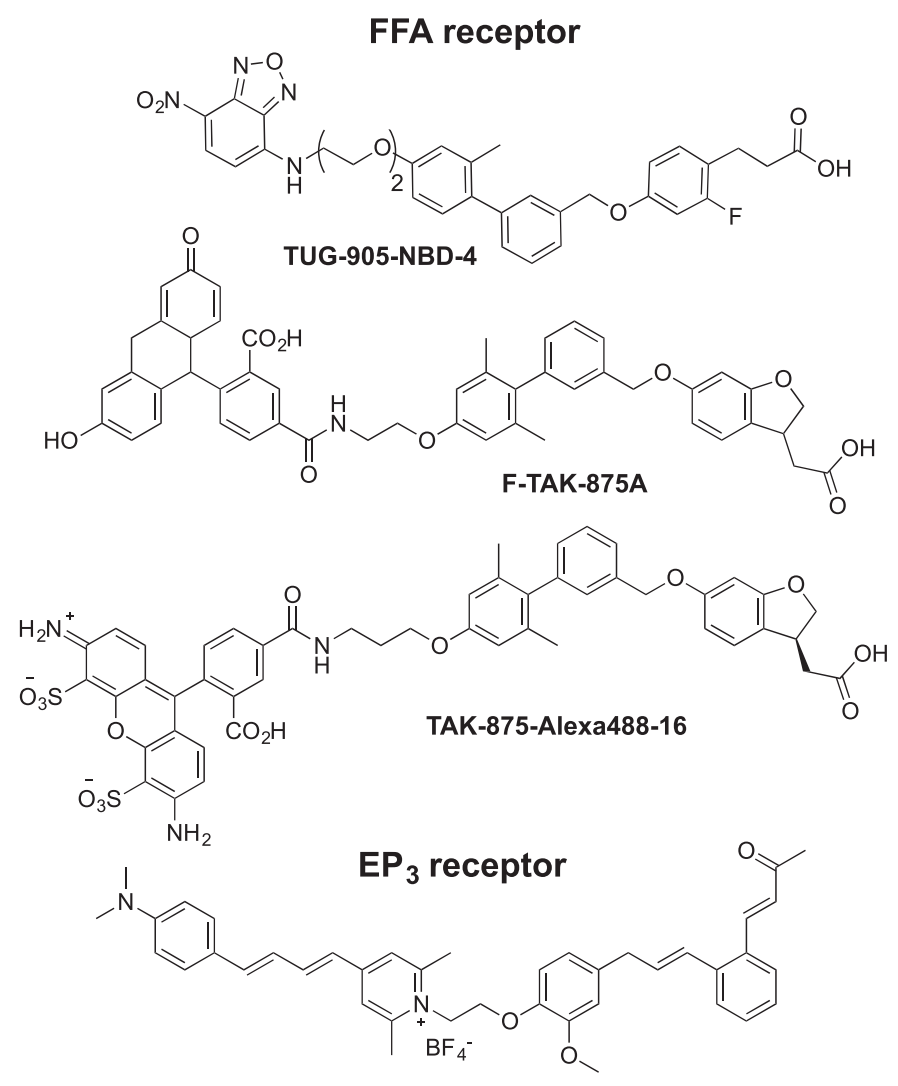

Pyryllium-labeled cinnamon acid derivative' 8 '

Fig. 5. FFA and prostanoid receptor fluorescent tools. future studies will aim to improve $\mathrm{EP}_{3}$ over $\mathrm{EP}_{4}$ receptor selectivity.

In the same body of work reporting photoactivatable ginkgolide derivatives as PAF receptor tools (Photoactivatable Covalent Tools), two ginkgolide derivatives tagged with a dansyl fluorophore at different positions were reported (Strømgaard et al., 2002). The most promising of these fluorescent conjugates had moderate PAF receptor affinity $[\mathrm{Ki}=0.96 \mu \mathrm{M}$, guinea pig (gp) $\mathrm{PAF}$; however, it was not evaluated further for PAF receptor fluorescent labeling or photoactivated covalent binding. Nevertheless, future development of fluorescently tagged ginkgolide derivatives as fluorescent tools may prove useful for PAF receptor interrogation.

2. Near-Infrared Wavelength Fluorescent Tools for In Vivo Imaging. Both the optical properties of tissues, including endogenous chemical components present, and choice of fluorophore can influence the depth that a suitable signal-to-noise fluorescent signal can be detected in vivo (reviewed in Pansare et al., 2012; Hong et al., 2017). Longer wavelength fluorophores such as those in the near-infrared (NIR) region $(700-900 \mathrm{~nm})$ and the now termed NIR-II region (1000-1700 nm) are well suited to in vivo imaging and typically can be detected at a tissue depth of up to $5-7 \mathrm{~mm}$ with good signal-to-noise resolution. As is the case with in vivo radioligands, the absorption, distribution, metabolism, and excretion of the tool in relation to the intended use need to be considered, along with careful characterization of in vivo versus in vitro selectivity.

There has been particular interest surrounding in vitro use/characterization and also in vivo use of NIR fluorescent tools to study $\mathrm{CB}_{2}$ receptor expression in malignant tumors. Synthesis of selective $\mathrm{CB}_{2}$ receptor SR144528 derivatives with linkers introduced to the pyrazole or 4-chloro phenyl position abolished $\mathrm{CB}_{2}$ receptor-binding affinity; however, incorporation of a linker at the benzylic position was more successful, resulting in the SR144528 linker derivative mbc94 $\left(K_{\mathrm{i}}=\right.$ $15 \mathrm{nM}$ at $\mathrm{mCB}_{2}$ ) (Fig. 4) (Bai et al., 2008; Sexton et al., 2011). Attachment of the fluorescent IRDye $800 \mathrm{CW}$ to mbc94 to give NIR-mbc94 (Fig. 4; Table 3) led to some loss in affinity $\left(K_{\mathrm{i}}=260 \mathrm{nM}\right.$ at $\left.\mathrm{mCB}_{2}\right)$. This fluorescent tool was successfully used in a multiwell high throughput screening assay using intact $\mathrm{CB}_{2}$-mid delayed brain tumor (DBT) cells (mouse DBT cells transfected with $\mathrm{CB}_{2}$ receptor); however, imaging experiments using primary microglia cells revealed a high level of NIRmbc94-nonspecific binding (Sexton et al., 2011).

The same group of researchers developed NIR760mbc94 (Fig. 4; Table 3) using the same $\mathrm{CB}_{2}$ receptor pharmacophore-linker mbc94 but a different fluorophore (NIR760) (Zhang et al., 2013). When $\mathrm{CB}_{2}$-mid DBT cells were incubated with NIR760-mbc94 in the presence and absence of the control nonfluorescent pharmacophore SR145528, the fluorescent intensity was reduced by only $40 \%$ compared with the control, 
indicating some nonspecific binding of the fluorescent tool, which the authors suggested was due to nonspecific protein binding because NIR760-mbc94 has a net negative charge. In a cancer model, $\mathrm{CB}_{2}$-mid DBT cells were injected subcutaneously into the right flank of healthy mice, and tumors were allowed to develop for 10 days. Zhang et al. (2015) then injected mice with NIR760-mbc94 and observed fluorescence on the whole body, followed by tumor-specific localization 48-72 hours postinjection. Injection with SR144528 1 hour prior to NIR760-mbc94 was carried out to determine specific $\mathrm{CB}_{2}$ receptor binding of NIR760-mbc94, and after 72 hours a $31 \%$ reduction in fluorescence of the tumor area/normal area ratio was observed. As $\mathrm{CB}_{2}$ receptor plays an important role in inflammation, this fluorescent tool has also been used for in vivo imaging of $\mathrm{mCB}_{2}$ receptor expression in a complete Freund's adjuvant-induced inflammation mouse model (Zhang et al., 2015). Low specific binding of NIR760-mbc94 was observed with inflammation-specific fluorescence visible only 36 hours postinjection.

The same group of researchers then conjugated a quinolone-based ligand with the NIR760 fluorophore to give NIR760-Q (Fig. 4; Table 3) (Wu et al., 2014b). Nonspecific binding was observed in experiments with Jurkat cells in the presence of the unlabeled control ligand 4Q3C, which the authors suggest may be due to the total negative charge of NIR760. The same research group subsequently developed the zwitterionic NIRfluorophore-containing ZW760-mbc94 (Fig. 4; Table 3) (Wu et al., 2014a). Specificity of ZW760-mbc94 for $\mathrm{CB}_{2}$ receptor was determined in vitro by incubating $\mathrm{CB}_{2}$-mid DBT cells in the absence or presence of the unlabeled control ligand 4Q3C, which afforded a $50 \%$ reduction in fluorescence intensity. This is a moderate improvement compared with negatively charged NIR760-mbc94, and development of fluorescent tools with improved in vivo selective binding is an ongoing challenge. The fluorescent tool ZW760-mbc94 was further evaluated by injection into mice 10 days after $\mathrm{CB}_{2}$-mid $\mathrm{DBT}$ cell inoculation in the right flank, and images showed high fluorescence in the liver as well as fluorescence throughout the whole body that persisted 72 hours after ZW760mbc94 injection. Ex vivo analysis revealed mice treated with the control blocking ligand 4Q3C showed a $47 \%$ reduced tumor:normal tissue fluorescence ratio ascompared to ZW760-mbc94-treated mice without blocking ligand, indicating some observed fluorescence was $\mathrm{CB}_{2}$ receptor-dependent.

Another fluorescent tool developed by the same research group is NIR760-XLP6 (Fig. 4; Table 3), which consists of a pyrazolopyrimidine pharmacophore conjugated via a linker to the NIR760 fluorophore (Ling et al., 2015). Experiments were carried out to determine in vivo receptor selectivity, which showed higher fluorescence ( $40 \%$ higher) in mice with $\mathrm{CB}_{2}$-mid $\mathrm{DBT}$ tumors as compared with $\mathrm{CB}_{1}$-mid DBT (DBT cells transfected with $\mathrm{CB}_{1}$ receptor) tumors. This research group has also developed a $\mathrm{CB}_{2}$ receptor-targeted photosensitizer IR700DX-mbc94 (Fig. 4; Table 3) by attaching a NIR fluorophore, IR700DX, to mcb94 (Zhang et al., 2014). In vivo experiments in mice revealed that IR700DXmbc94 inhibited growth of $\mathrm{CB}_{2}$ receptor-positive tumors following light (wavelength $670-710 \mathrm{~nm}$ ) irradiation, but not that of the $\mathrm{CB}_{2}$ receptor-negative tumors (Jia et al., 2014). This is an interesting novel approach to treating tumors overexpressing $\mathrm{CB}_{2}$ receptor. A patent application (Bornhop et al., 2013) has been published by the same group of researchers that describes the use of SR144528 derivatives tethered to an IRDye800CW fluorophore, a topoisomerase inhibitor (such as etoposide), and a gadolinium chelate. The potential applications of these SR144528 derivatives claimed by the patent include use as a molecular imaging tool and as a targeted drug delivery system.

The development and use of fluorescent tools for GPCRs are a rapidly developing field. There are several reports of selective $\mathrm{CB}_{2}$ receptor fluorescent tools; however, there is a lack of selective $\mathrm{CB}_{1}$ receptor fluorescent tools, and no doubt this is an area of intensive research. Selective fluorescent tools for the other FFA, S1P, LPA, prostanoid, leukotriene, PAF, and GPBA receptors based on synthetic pharmacophores will most likely be developed in the future, which will facilitate some exciting biologic experiments.

\section{Covalent Tools}

\section{A. Characteristics and Design Rationale}

A covalent ligand (or affinity label) is a tool that, once in place at the target receptor, is able to form a covalent bond with one or more amino acid side chains located at or near the ligand binding site (Weichert and Gmeiner, 2015). Covalent tools should ideally be able to first interact with the receptor noncovalently with high affinity and then engage in a controllable and/or specific reaction(s). High affinity will increase the concentration of covalent ligand at the binding site and therefore increase covalent labeling.

Covalent tools can be classified as photoactivatable and/or electrophilic, each of which can be irreversible or reversible. Photoactivatable ligands (or photoaffinity labels) possess a chemically inert moiety such as an azide or benzophenone that can be irradiated to a highly reactive nitrene or biradical, which can form a covalent bond with a nearby amino acid. Electrophilic ligands contain a reactive electrophilic functional group that can react with a nucleophilic amino acid side chain to form a covalent bond. Investigating affinity and specificity for the target receptor, as well as stability of the covalent ligand, is important for the validation of a covalent probe. Covalent binding is usually quantified using a radioligand-binding assay by calculating the decrease in radioligand $B_{\max }$ after incubation of receptors 
with the covalent ligand and washing to remove unreacted ligand (Picone et al., 2002). There has been reinvigorated interest in covalent drugs (Singh et al., 2011; Nussinov and Tsai, 2015) and studying the kinetics of irreversible and reversible covalent ligand binding. A number of studies have investigated potency and modulation of drug-protein residence times by adjusting the covalent reactivity of drugs such as kinase inhibitors (Flanagan et al., 2014; Krishnan et al., 2014; Bradshaw et al., 2015), a concept that is also applicable to covalent tools for GPCRs.

\section{B. Applications of Covalent Tools}

Covalently linked tools have been used to investigate key amino acid residues involved in ligand binding and receptor activation, as well as in receptor-signaling studies and in vivo physiologic research. When combined with in silico modeling and site-directed mutagenesis, covalent tools can enable characterization of the spatial orientation and topography of receptor ligand binding site(s). Indeed, covalent tools have been employed in the mapping of ligand binding sites of dopamine transporters (Vaughan et al., 2005), GPCRs such as $\alpha_{2}$-adrenoceptor (Matsui et al., 1989) and adenosine receptor (Kennedy et al., 1996), and enzymes such as the 2-AG-deactivating monoacylglycerol lipase (Zvonok et al., 2008). A covalent ligand-receptor interaction has aided in the isolation and purification of other class A GPCR subtypes (Dohlman et al., 1988) and improved receptor stability for GPCR X-ray crystal structure determination (Palczewski et al., 2000; Choe et al., 2011). Covalent ligands have also been useful in establishing the receptor targets of biologically active compounds (Sumranjit and Chung, 2013).

Antibodies, peptide sequencing, or mass spectrometry is often used to analyze a covalent ligand-GPCR complex. By comparison with fluorescent ligands and radioligands, covalent tools discussed in this work do not possess the functionality for direct use in imaging studies and for the most part have been used in cellbased studies. When designing an in vivo covalent ligand, it is important to consider the safety profile of irreversible binding, as off-target interactions could result in, for example, potentially immunogenic extracellular protein-ligand adducts (Johnson et al., 2010).

There are numerous reports of the utility of covalent tools for CB receptors and to a lesser extent leukotriene, prostanoid, and PAF receptors; however, to date there have been no reports of covalent ligands for FFA, S1P, or LPA receptors. A large number of covalent tools based on classic, nonclassic, and ECB CB receptor scaffolds have been developed by the Makriyannis group (ligands named with the prefix "AM"). Their approach, termed ligand-assisted protein structure, is to develop a range of ligands with various reactive moieties at different ligand positions to elucidate the role of different receptor amino acid side chains, thus characterizing the ligand binding site of $\mathrm{CB}$ receptor (Picone et al., 2002).

1. Photoactivatable Covalent Tools. The most commonly used inert groups capable of photoactivation are azides, benzophenones, and diazirines. An advantage of photoactivated ligands is that the highly reactive species generated in situ is able to form a covalent bond with any amino acid nearby, compared with electrophilic covalent ligands that are limited to reaction with only one or two nucleophilic amino acid side chains (Sumranjit and Chung, 2013). The highly reactive species generated can covalently bind to the receptors through insertion into bonds (e.g., C-H) in the peptide backbone and amino acid side chains (Cavalla and Neff, 1985). Desirable properties of a photoactivated ligand include high receptor affinity, activatable at a wavelength that does not cause damage to the target receptor or biosystem, the generation of a reactive group with a short lifetime, indiscriminate or finely-tuned formation of a covalent bond with any nearby amino acid, and formation of a stable irreversible adduct (Vodovozova, 2007).

Initial efforts to develop covalent tools for CB receptors focused on analogs of $\Delta^{8}$-THC, which has a similar affinity for $\mathrm{CB}_{1}$ receptor, but is more stable than the naturally more prevalent $\Delta^{9}$-THC isomer. A photoactivatable azido group was positioned at the THC aliphatic chain terminus, as SAR showed this position to be tolerant of bulky groups (Charalambous et al., 1992). This ligand, 5'azido- $\Delta^{8}$-THC AM91 (Fig. 6; Table 4), exhibited approximately twofold increased affinity to that of $\Delta^{8}$-THC $\left(K_{\mathrm{i}}=35 \pm 11 \mathrm{nM}\right.$ at $\left.\mathrm{rCB}_{1}\right)$. AM91 was developed shortly after cloning of $\mathrm{CB}_{1}$ receptor with the intention of aiding receptor isolation and characterization and was a prototype for the next generation of photoactivatable ligands. Increasing interest in CB receptors and the need for tools to identify receptor subtypes and enable receptor isolation, purification, and characterization drove the development of subsequent $\mathrm{CB}$ receptor covalent tools.

The same research group radioiodinated AM91 by introducing $\left[{ }^{125} \mathrm{I}\right]$ ortho to the phenolic group to give 2-iodo-5' azido- $\Delta^{8}$-THC (2-[ $\left.\left.{ }^{125} \mathrm{I}\right]-\mathrm{AM} 91\right)$ (Fig. 6; Table 4) (Burstein et al., 1991). The 2-[ $\left.{ }^{125} \mathrm{I}\right]-\mathrm{AM} 91$, equilibrated with tissue and exposed to UV light to induce azide to nitrene conversion, could detect $\mathrm{CB}$ receptor expression in mouse cerebral cortex $\left(K_{\mathrm{d}}=5.60 \mathrm{pM}\right)$ and mouse lymphoma cells $\left(K_{\mathrm{d}}=9.38 \mathrm{pM}\right)$. Samples of mouse brain analyzed by SDS-PAGE and autoradiography showed formation of a covalent bond between ligand and CB receptor. This experiment provided the earliest evidence of a covalent ligand-CB receptor entity and provided a clue to the existence of receptor subtypes as a fainter, lower molecular weight band on the gel was also observed. This other band was later shown to be $\mathrm{CB}_{2}$ receptor (Makriyannis, 2014).

Distinct chemical classes of photoaffinity labels can provide insight into the ligand-binding mode and the 
topography of the $\mathrm{CB}$ receptor ligand binding site(s). A series of photoactivatable $\mathrm{CB}$ receptor ligands featuring a heteroaroyl group at $\mathrm{C} 3$ in place of an alkyl chain were synthesized, including a $\mathrm{CB}_{2}$ receptor-selective 3-benzothiophenyl-derivative AM967 $\left(K_{\mathrm{i}}=34.2 \mathrm{nM}\right.$ at $\mathrm{mCB}_{2}, 124.8 \mathrm{nM}$ at $\mathrm{hCB}_{2}, 1254 \mathrm{nM}$ at $\mathrm{rCB}_{1}$ ) (Fig. 6; Table 4) (Dixon et al., 2012). Photolysis of aryl phenones with UV light at approximately $350 \mathrm{~nm}$ generates a highly reactive triplet-state ketone intermediate, which can form covalent bonds through insertion in C-H bonds (Vodovozova, 2007). Receptor photolabeling of $\mathrm{CB}_{2}$ receptor using AM967 was measured at $67 \%$ (reduction in specific binding of $\left.\left[{ }^{3} \mathrm{H}\right] \mathrm{CP}-55,940\right)$ in HEK293 membrane preparations expressing $\mathrm{mCB}_{2}$ receptor (Dixon et al., 2012). This covalent series provided interesting SAR data on heteroaroyl-containing $\mathrm{CB}_{2}$ receptor ligands. Future experiments with AM967 could elucidate key amino acids specifically involved in the binding of arylphenone analogs, expanding the structural understanding of $\mathrm{CB}_{2}$ receptor and further enabling structurebased design of subtype-selective drugs.

The classic CB-based tool AM993, which has a C3 adamantyl group, has been synthesized to inform receptor molecular recognition of this fixed conformation adamantyl moiety (Ogawa et al., 2015). AM993 (Fig. 6; Table 4) behaved as an agonist at $\mathrm{rCB}_{1}$ receptor with an $\mathrm{EC}_{50}=2.4 \mathrm{nM}$ and $E_{\text {max }}=45 \%$ and as a neutral antagonist at $\mathrm{hCB}_{2}$ receptor. Successful covalent labeling of CB receptors following pretreatment with 10 -fold above the $K_{\mathrm{i}}$ of AM993 was demonstrated with a $67 \%$ reduction in specific binding of $\left[{ }^{3} \mathrm{H}\right] \mathrm{CP}-55,940$ at $\mathrm{rCB}_{1}$ and a $60 \%$ reduction at $\mathrm{hCB}_{2}$ receptor. A series of electrophilic and photoactivatable aryl pyrazole compounds based on the high-affinity $\mathrm{CB}_{1}$ receptor antagonist rimonabant have been developed (Howlett et al., 2000). However, most of these compounds did not maintain the affinity of the parent compound, and the best in this series irreversibly labeled $\mathrm{rCB}_{1}$ receptor at $\mathrm{IC}_{50}=28 \mathrm{nM}$. Modified ECBs have also been developed as CB receptor covalent ligands. AM3661 is based on the structure of AEA and incorporates a cyclopropylamide moiety at the head group for improved $\mathrm{CB}_{1}$ affinity and a photoactivatable azide at the terminal alkyl chain. AM3661 (Fig. 6; Table 4) was shown to irreversibly label $68 \%$ of $\mathrm{rCB}_{1}$ receptor when used at $18 \mathrm{nM}$ (Li et al., 2005). Binding assays were carried out in the presence of a serine protease inhibitor to avoid AM3661 hydrolysis by fatty acid amide hydrolase (FAAH), a key enzyme in ECB metabolism. ECB-based covalent tools can be used to reveal key information regarding the binding and signaling of AEA and 2-AG as well as ECBlike ligands.

There are also a number of $\mathrm{CB}$ receptor photoactivatable tools reported in review literature but without published primary experimental data, which are summarized below. The tool $7^{\prime}-\mathrm{N}_{3^{-}}-1^{\prime}, 1^{\prime}$-dimethylheptyl- $\Delta^{8}-\mathrm{THC}$, the $1^{\prime}$-geminal dimethyl and seven carbon aliphatic chain analog of AM91, was reported to give improved affinity $\left(K_{i}=0.4 \mathrm{nM}\right.$ at $\left.\mathrm{CB}_{1}\right)$ compared with AM91 (Picone et al., 2002). This improved affinity would be advantageous when working in native cell lines with low CB receptor expression. The (-)-11-hydroxy-7' azido$\Delta^{8}$-THC (AM836) was ascribed an $\mathrm{IC}_{50}=0.16 \mathrm{nM}$ at $\mathrm{CB}_{1}$ receptor (Palmer et al., 2002; Thakur et al., 2005). Two tools containing an azido instead of the 10-methyl of $1^{\prime}, 1^{\prime}$-dimethylheptylhexahydrocannabinol have been reported. AM869 contains an iodide at the terminus of the seven-carbon chain $\left(K_{\mathrm{i}}=0.67 \mathrm{nM}\right.$ at $\mathrm{CB}_{1}, 0.72 \mathrm{nM}$ at
CB receptor photoactivatable

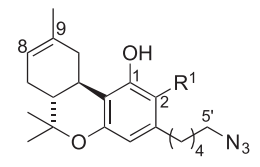

AM91, $\mathrm{R}^{1}=\mathrm{H}$ $2-\left[{ }^{125} \mathrm{I}\right]-\mathrm{AM} 91, \mathrm{R}^{1}={ }^{125}$ |

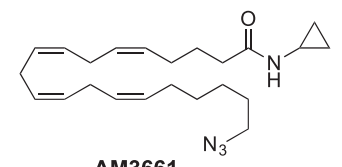

AM3661

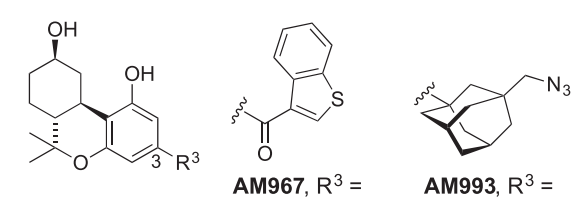

CB receptor bifunctional

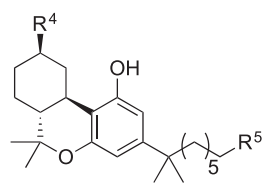

AM5823, $\mathrm{R}^{4}=\mathrm{CH}_{2} \mathrm{NCS}, \mathrm{R}^{5}=\mathrm{NCS}$ AM5822, $\mathrm{R}^{4}=\mathrm{CH}_{2} \mathrm{NCS}, \mathrm{R}^{5}=\mathrm{N}_{3}$ AM859, $\mathrm{R}^{4}=\mathrm{N}_{3}, \mathrm{R}^{5}=\mathrm{CH}_{2} \mathrm{~N}_{3}$

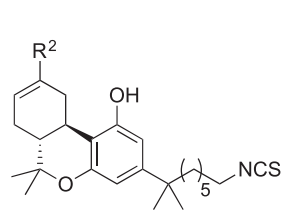

AM708, $\mathrm{R}^{2}=\mathrm{CH}_{2} \mathrm{OH}$ 7'-NCS-DMH-THC, $\mathrm{R}^{2}=\mathrm{CH}_{3}$
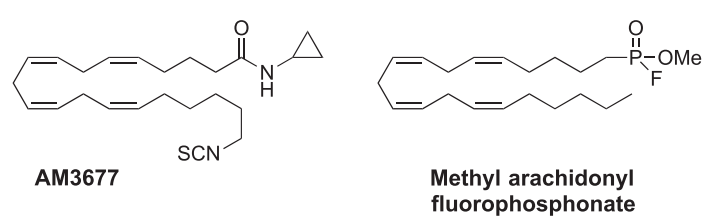

CB receptor electrophilic

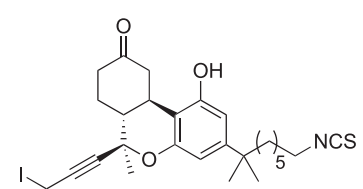

AM960

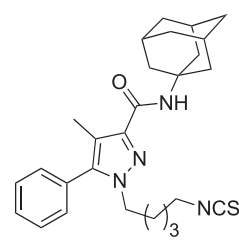

AM1336
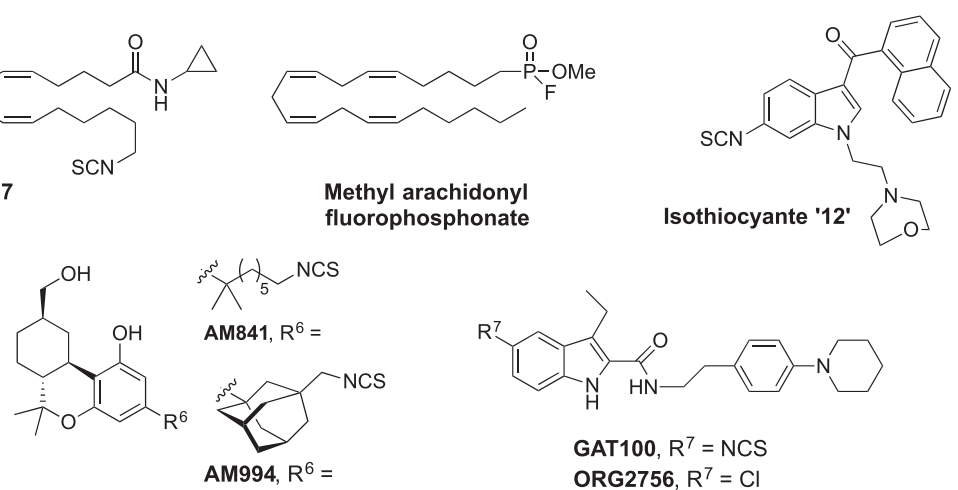

Fig. 6. CB receptor photoactivatable, electrophilic, and bifunctional covalent tools. 
TABLE 4

$\mathrm{CB}$, leukotriene, prostanoid, and PAF receptor covalent ligands

\begin{tabular}{|c|c|c|c|c|}
\hline Tool & Data & Function & Covalent Binding $^{a}$ & Reference \\
\hline \multicolumn{5}{|c|}{ CB Receptor Photoactivatable Ligands } \\
\hline AM91 & $\mathrm{rCB}_{1} K_{\mathrm{i}}=19 \pm 6 \mathrm{nM}$ & & $85 \%$ at $1 \mu \mathrm{M}$ & Charalambous et al., 1992 \\
\hline $2-\left[{ }^{125} \mathrm{I}\right]-\mathrm{AM} 91$ & $\begin{array}{l}\mathrm{mCB}_{1} K_{\mathrm{d}}=5.6 \mathrm{pM}, 9.38 \\
\end{array}$ & & & Burstein et al., 1991 \\
\hline AM967 & $\begin{array}{l}\mathrm{rCB}_{1} K_{\mathrm{i}}=1254 \mathrm{nM} \\
\mathrm{hCB}_{2} K_{\mathrm{i}}=124.8 \mathrm{nM}\end{array}$ & & & Dixon et al., 2012 \\
\hline & $\mathrm{mCB}_{2} K_{\mathrm{i}}=34.3 \mathrm{nM}$ & & $67 \%$ at $342 \mathrm{nM}$ & \\
\hline AM993 & $\mathrm{rCB}_{1} K_{\mathrm{i}}=4.4 \mathrm{nM}$ & Agonist & $67 \%$ at $44 \mathrm{nM}$ & Ogawa et al., 2015 \\
\hline & $\begin{array}{l}\mathrm{hCB}_{2} K_{\mathrm{i}}=9.6 \mathrm{nM} \\
\mathrm{mCB}_{2} K_{\mathrm{i}}=26.4 \mathrm{nM}\end{array}$ & Antagonist & $60 \%$ at $96 \mathrm{nM}$ & \\
\hline AM3661 & $\begin{array}{l}\mathrm{rCB}_{1} K_{\mathrm{i}}=0.9 \pm 0.2 \mathrm{nM} \\
\mathrm{mCB}_{2} K_{\mathrm{i}}=57.6 \pm 19 \mathrm{nM}\end{array}$ & & $68 \%$ at $18 \mathrm{nM}$ & Li et al., 2005 \\
\hline \multicolumn{5}{|c|}{ CB Receptor Electrophilic Ligands } \\
\hline AM708 & $\mathrm{rCB}_{1} \mathrm{IC}_{50}=1.6 \pm 0.3 \mathrm{nM}$ & & $80 \%$ at $10 \mathrm{nM} \sim 100 \%$ at $100 \mathrm{nM}$ & Guo et al., 1994 \\
\hline 7'-NCS-DMH-THC & $\mathrm{rCB}_{1} \mathrm{IC}_{50}=0.66 \mathrm{nM}$ & & $83 \%$ at $3.3 \mathrm{nM}$ & Morse et al., 1995 \\
\hline \multirow{2}{*}{ AM841 } & $\mathrm{hCB}_{1} K_{\mathrm{i}}=9.05 \pm 2.06 \mathrm{nM}$ & Agonist & & Picone et al., 2005 \\
\hline & $\mathrm{hCB}_{2} K_{i}=1.51 \mathrm{nM}$ & Agonist & & Pei et al., 2008 \\
\hline \multirow[t]{2}{*}{ AM994 } & $\begin{array}{l}\mathrm{rCB}_{1} K_{\mathrm{i}}=3.0 \mathrm{nM} \\
\mathrm{EC}_{50}=0.8 \mathrm{nM} \text { and } \mathrm{E}_{\max } \\
\quad=94 \%\end{array}$ & Agonist & $63 \%$ at $30 \mathrm{nM}$ & Ogawa et al., 2015 \\
\hline & $\begin{array}{l}\mathrm{mCB}_{2} K_{\mathrm{i}}=34.6 \mathrm{nM} \\
\mathrm{hCB}_{2} K_{\mathrm{i}}=10.3 \mathrm{nM}, \\
\mathrm{EC}_{50}=>400 \mathrm{nM} \text { and } \mathrm{E}_{\max } \\
\quad=-91 \%\end{array}$ & Inverse agonist & $74 \%$ at $103 \mathrm{nM}$ & \\
\hline AM3677 & $\begin{array}{l}\mathrm{rCB}_{1} K_{\mathrm{i}}=1.3 \pm 0.2 \mathrm{nM} \\
\mathrm{mCB}_{2} K_{\mathrm{i}}=48.5 \pm 13 \mathrm{nM}\end{array}$ & Agonist & $58 \%$ at $26 \mathrm{nM}$ & Li et al., 2005 \\
\hline AM1336 & $\mathrm{hCB}_{2} K_{\mathrm{i}}=0.54 \mathrm{nM}$ & Inverse agonist & $60 \%$ at $5.4 \mathrm{nM}$ & Mercier et al., 2010 \\
\hline Isothiocyanate 12 & $\mathrm{rCB}_{1} \mathrm{IC}_{50}=160 \mathrm{nM}$ & Agonist & $70 \%$ at $1 \mu \mathrm{M}$ & Yamada et al., 1996 \\
\hline GAT100 & $\begin{array}{l}\mathrm{hCB}_{1} \mathrm{EC}_{50}=174 \mathrm{nM} \\
\quad(\mathrm{cAMP} \text { assay }) \mathrm{hCB}_{1} \\
\mathrm{EC}_{50}=2.09 \mathrm{nM} \\
(\beta \text {-arrestin assay })\end{array}$ & $\begin{array}{l}\text { Negative allosteric } \\
\text { modulator }\end{array}$ & & Kulkarni et al., 2016 \\
\hline $\begin{array}{l}\text { Methyl arachidonyl } \\
\text { fluorophosphonate }\end{array}$ & $\mathrm{rCB}_{1} \mathrm{IC}_{50}=20 \mathrm{nM}$ & Antagonist & & $\begin{array}{l}\text { Fernando and Pertwee, } \\
1997\end{array}$ \\
\hline \multicolumn{5}{|c|}{ CysLT Receptor Photoactivatable Ligands } \\
\hline$\left[{ }^{125} \mathrm{I}\right]$-azido-LTD 4 & $\begin{array}{l}\text { gpCysLT }_{1} K i=1.7 \mathrm{nM}^{b} \\
K_{d}=0.3 \mathrm{nM}\end{array}$ & & & $\begin{array}{l}\text { Metters and Zamboni, } \\
1993\end{array}$ \\
\hline$\left[{ }^{125} \mathrm{I}\right]-\mathrm{L}-745310$ & $\begin{array}{l}\operatorname{gpCysLT}_{1} \mathrm{IC}_{50}=27 \mathrm{nM}^{b} \\
53 \mathrm{nM}^{a}\end{array}$ & Antagonist & & Gallant et al., 1998 \\
\hline $\begin{array}{l}7 Z, 9 E \mathrm{LTD}_{4} \text { Aryldiazonium } \\
\text { derivative }\end{array}$ & $\begin{array}{l}\operatorname{gpCysLT}_{2} K_{i}=80 \pm 9 \mathrm{nM} \\
\operatorname{gpCysLT}_{1} K i=8 \pm 0.9 \mu \mathrm{M}\end{array}$ & & & Klotz et al., 1993 \\
\hline $\begin{array}{l}7 E, 9 E \mathrm{LTD}_{4} \text { Aryldiazonium } \\
\text { derivative }\end{array}$ & $\begin{array}{l}\operatorname{gpCysLT}_{2} K_{i}=110 \pm \\
14 \mathrm{nM} \\
\operatorname{gpCysLT}_{1} K_{i}=40 \pm 12 \mu \mathrm{M}\end{array}$ & & & \\
\hline \multicolumn{5}{|c|}{ LTB4$_{1}$ Receptor Photoactivatable Ligands } \\
\hline $\begin{array}{l}\text { Aryl azide } \mathrm{LTB}_{4} \text { derivative } \\
\quad 4 \mathrm{~b} \alpha\end{array}$ & $\mathrm{hLTB}_{1} \mathrm{IC}_{50}=0.7 \mu \mathrm{M}$ & Antagonist & $40 \%$ at $1: 1$ molar ratio to $\mathrm{h}_{-\mathrm{LTB}} 4_{1}$ & Durand et al., 2000 \\
\hline \multicolumn{5}{|l|}{ PAF Photoactivatable Ligands } \\
\hline$\left[{ }^{125} \mathrm{I}\right] \mathrm{AAGP}$ & $\begin{array}{l}\text { rbtPAF } \mathrm{EC}_{50}=3.2 \pm 1.9 \\
\mathrm{nM}^{\mathrm{a}} \\
K_{d}=2.4 \pm 0.7 \mathrm{nM}\end{array}$ & Agonist & & Chau et al., 1989 \\
\hline $\begin{array}{l}\text { Tetrafluorophenylazide } \\
\text { ginkgolide B derivative }\end{array}$ & $\operatorname{gpPAF} K_{i}=90 \mathrm{nM}$ & Antagonist & Not demonstrated & Strømgaard et al., 2002 \\
\hline \multicolumn{5}{|c|}{ TP Receptor Photoactivatable Ligands } \\
\hline I-APA-PhN ${ }_{3}$ & $\mathrm{hTP} K_{i}=290 \mathrm{nM}$ & & $\begin{array}{l}58 \% \text { at } 20 \mu \mathrm{M} \text { (reduction in specific } \\
\text { binding of U46619) }\end{array}$ & $\begin{array}{l}\text { Arora et al., 1987; } \\
\quad \text { Kattelman et al., } 1987\end{array}$ \\
\hline$\left[{ }^{125} \mathrm{I}\right]$ PTA-azido & $\mathrm{hTP} K_{d}=11 \mathrm{nM}$ & & & Mais et al., 1989 \\
\hline I-PTA-PON 3 & $\mathrm{hTP} K_{d}=9.5 \mathrm{nM}$ & Antagonist & $\begin{array}{l}52 \% \text { at } 163 \mathrm{nM}, 77 \% \text { at } 326 \mathrm{nM} \\
\left(\text { reduction in I-PTA-OH } B_{\max }\right)\end{array}$ & Mais et al., 1990 \\
\hline$\left[{ }^{125} \mathrm{I}\right] \mathrm{SAP}-\mathrm{N}_{3}$ & $\mathrm{hTP} K_{d}=382 \pm 41 \mathrm{pM}$ & & & Mais et al., 1991 \\
\hline \multicolumn{5}{|c|}{ IP Receptor Photoactivatable Ligands } \\
\hline$\left[{ }^{3} \mathrm{H}\right] \mathrm{APNIC}$ & $\mathrm{mIP} K_{d}=4.7 \mathrm{nM}$ & & $\begin{array}{l}80 \% \text { of specific binding of }\left[{ }^{3} \mathrm{H}\right] \\
\text { APNIC at } 13 \mathrm{nM}\end{array}$ & Ito et al., 1992 \\
\hline \multicolumn{5}{|c|}{ EP Receptor Photoactivatable Ligands } \\
\hline$\left[{ }^{3} \mathrm{H}\right]$ azido-PGE $\mathrm{P}_{2}$ & $\mathrm{bEP} \mathrm{IC}_{50}=400 \mathrm{nM}^{\mathrm{a}}$ & & & Michalak et al., 1990 \\
\hline
\end{tabular}

${ }^{a}$ Covalent binding for all CB photoactivatable and electrophilic ligands was measured as a percentage reduction in $\left[{ }^{3} \mathrm{H}\right] \mathrm{CP}-55,940-$ specific binding.

${ }^{b}$ Affinity data for cold analogs. 
$\mathrm{CB}_{2}$ ), whereas AM1708 has both an alkene and ${ }^{125} \mathrm{I}$ at the terminus of the alkyl chain $\left(K_{\mathrm{i}}=0.8 \mathrm{nM}\right.$ at $\mathrm{CB}_{1}, 0.85 \mathrm{nM}$ at $\mathrm{CB}_{2}$ ) (Khanolkar et al., 2000).

Initial characterization of $\mathrm{CysLT}_{1}$ receptor was aided by a radioiodinated photoactivatable azido analog of $\mathrm{LTD}_{4}$. $\left[{ }^{125} \mathrm{I}\right]$-azido-LTD $4 K_{i}=1.7 \mathrm{nM}$ (nonradioactive analog)] (Fig. 7; Table 4) was able to selectively covalently label a $45-\mathrm{kDa}$ protein in guinea pig lung membranes (Metters and Zamboni, 1993). LTD ${ }_{4}, \mathrm{LTE}_{4}$, $\mathrm{LTC}_{4}$, and MK-0571 (a CysLT 1 antagonist) were able to inhibit the photolabeling of the $45-\mathrm{kDa}$ protein by $\left[{ }^{125} \mathrm{I}\right]-$ azido-LTD $\mathrm{LT}_{4}$ with similar potencies to their $\mathrm{IC}_{50}$ values at $\mathrm{CysLT}_{1}$ receptor, providing evidence that this protein is $\mathrm{CysLT}_{1}$ receptor. However, $\left[{ }^{125} \mathrm{I}\right]$-azido-LTD ${ }_{4}$ was also found to nonselectively label guinea pig serum albumin. Subsequently, the more synthetically accessible photoaffinity probe $\left[{ }^{125} \mathrm{I}\right]-\mathrm{L}-745310$, an analog of $\mathrm{CysLT}_{1}$ receptor antagonist montelukast, containing a trifluoromethyl diazirine as the photoactivatable group, was developed (Fig. 7; Table 4) (Gallant et al., 1998). The reactive carbene generated upon protolysis $(350 \mathrm{~nm})$ of the diazirine can insert into $\mathrm{C}-\mathrm{H}$ bonds. $\left[{ }^{125} \mathrm{I}\right]-\mathrm{L}-745310$ was able to label the same $45-\mathrm{kDa}$ protein in guinea pig lung preparations, acting as an antagonist $\left(\mathrm{IC}_{50}=27 \mathrm{nM}, 53 \mathrm{nM}\right.$ at gpCysLT $\left.{ }_{1}\right)$. High levels of nonspecific labeling were reduced with addition of a detergent and optimization of irradiation time and temperature.

The endogenous leukotrienes possess some innate photoactivatable labeling properties due to the presence of conjugated double bonds, and this has been exploited (Falk et al., 1989; Müller et al., 1991; Slipetz et al., 1993; Nicosia et al., 1995). However, this process requires cryofixation of the receptor-ligand complex to reduce significant nonspecific labeling.

Photoactivatable peptidoleukotriene analogs for $\mathrm{CysLT}_{2}$ receptor have been developed, containing either $7 Z, 9 E$ or $7 E, 9 E$ dienic moieties in an effort to improve stability of the endogenous leukotrienes (Klotz et al., 1993). The aryldiazonium-substituted dienic $\mathrm{LTD}_{4}$ derivatives (Fig. 7; Table 4) showed greater selectivity for $\mathrm{CysLT}_{2}$ receptor than the less potent arylazido derivatives. In addition, irradiation of the azido analogs at $245 \mathrm{~nm}$ overlaps with the absorption of the dienic moiety ( $235 \mathrm{~nm}$ ), resulting in simultaneous decomposition of both azide and diene, whereas only a single reactive species is produced when the diazonium ana$\operatorname{logs}$ are irradiated at $360 \mathrm{~nm}$.

Characterization of PAF receptor was aided by a similar approach using $\left.{ }^{[25} \mathrm{I}\right] \mathrm{AAGP}$, a photoactivatable, radiolabeled derivative of PAF (Fig. 7; Table 4) (Chau et al., 1989). $\left[{ }^{125} \mathrm{I}\right] \mathrm{AAGP}$ showed saturable, high-affinity binding in rabbit platelet membranes $\left(K_{d}=2.4 \pm 0.7\right.$ $\mathrm{nM}, B_{\max }=1.1 \pm 0.2 \mathrm{pmol} / \mathrm{mg} ; \mathrm{EC}_{50}$ of nonradioactive analog $=3.2 \pm 1.9 \mathrm{nM}$ ), and photolabeling identified a protein of $52 \mathrm{kDa}$ as the $\mathrm{PAF}$ receptor. In another study, a series of ginkgolide $\mathrm{B}$ and ginkgolide $\mathrm{C}$ derivatives were synthesized containing varying photoactivatable groups (Strømgaard et al., 2002). These were all found to act as antagonists at PAF receptor with the highest affinity compound a ginkgolide B derivative containing a tetrafluorophenylazide $\left(K_{i}=90 \mathrm{nM}\right.$ at gpPAF) (Fig. 7; Table 4$)$ and being more potent than ginkgolide $\mathrm{B}\left(K_{i}=\right.$ $0.56 \mu \mathrm{M}$ at gpPAF receptor). This ligand could potentially be used to investigate ginkgolide interactions with PAF receptor; however, as yet covalent binding has not been demonstrated.

The first prostanoid receptor covalent tool developed was a diazonium salt of 9,11-dimethylmethano-11,12methano-16-(4-aminophenoxy)13,14-dihydro-13-aza-15 alpha beta-omega-tetranor TXA2, PTA-POA, which was shown to irreversibly bind to hTP receptor, but affinity was unable to be determined (Mais et al., 1986). An iodinated azide derivative of 13-azaprostanoic acid, I-APA-PhN ${ }_{3}$ (Fig. 7; Table 4), was able to irreversibly bind TP receptor with moderate affinity $\left(K_{i}=290 \mathrm{nM}\right.$ at hTP) and irreversibly inhibit human platelet aggregation (Arora et al., 1987; Kattelman et al., 1987). The TP receptor photoaffinity probe, $\left[{ }^{125} \mathrm{I}\right] \mathrm{PTA}$-azido (Fig. 7; Table 4), had good affinity $\left(K_{d}=11 \mathrm{nM}\right.$ at hTP) and was able to label three protein bands of 43,39 , and $27 \mathrm{kDa}$, but it was not clear which of these was TP receptor (Mais et al., 1989). $\left[{ }^{125} \mathrm{I}\right] \mathrm{PTA}$-azido was used to determine the isoelectric point of TP receptor (Mais and Halushka, 1989).

Another TP receptor photoaffinity probe, I-PTA$\mathrm{PON}_{3}$ (Fig. 7; Table 4), was used to inhibit human platelet aggregation and irreversibly label hTP receptor (Mais et al., 1990). A radioiodinated photoaffinity probe $\left[{ }^{125} \mathrm{I}\right] \mathrm{SAP}-\mathrm{N}_{3}$ (Fig. 7; Table 4) irreversibly labeled human platelet TP receptor with high affinity (Mais et al., 1991). [ $\left.{ }^{125} \mathrm{I}\right] \mathrm{SAP}-\mathrm{N}_{3}$ was used with SDS-PAGE autoradiography to identify TP receptor with a molecular weight of $50-51 \mathrm{kDa}$, and subsequent digestion of this photoaffinity-labeled receptor identified two $N$-linked glycosylation sites (Mais et al., 1992). Proteolytic cleavage studies of purified, $\left.{ }^{[25} \mathrm{I}\right] \mathrm{SAP}-\mathrm{N}_{3}$-labeled TP receptor were carried out to localize the ligand binding domain to amino acids 99-192 (True and Mais, 1994).

A PGI ${ }_{2}$ analog, $\left[{ }^{3} \mathrm{H}\right]$ APNIC (Fig. 7; Table 4), was used to characterize IP receptor. $\left[{ }^{3} \mathrm{H}\right]$ APNIC had good affinity $\left(K_{d}=4.7 \mathrm{nM}, B_{\max } 0.58 \mathrm{pmol} / \mathrm{mg}\right.$ protein, mouse mastocytoma P-815 cells) and photolabeled IP receptor with good efficiency (80\% of specific binding of $\left[{ }^{3} \mathrm{H}\right]$ APNIC at $13 \mathrm{nM}$ ), and was able to identify a $43-\mathrm{kDa}$ protein in mouse mastocytoma and a $45-\mathrm{kDa}$ protein in porcine platelets as IP receptor (Ito et al., 1992; Suzuki et al., 1992).

A moderate affinity azidophenacyl ester of $\mathrm{PGE}_{2}$ (azido-PGE ${ }_{2}$ ) (Fig. 7; Table 4) was synthesized for use as a tool to isolate and identify EP receptor (Michalak et al., 1990). The radiolabeled analog, $\left[{ }^{3} \mathrm{H}\right]$ azido- $\mathrm{PGE}_{2}$, was able to covalently label a protein of $100 \mathrm{kDa}$ in isolated bovine cardiac sarcolemmal vesicles, and this photolabeling could be inhibited with excess unlabeled 


\section{CysLT receptor}

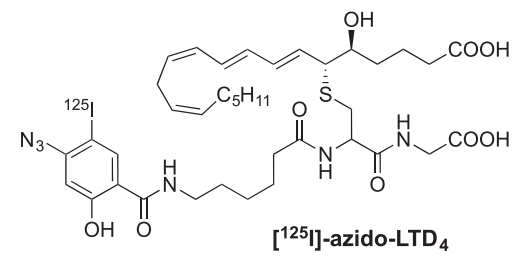

[125]]-azido-LTD ${ }_{4}$

$\mathrm{BLT}_{1}$ receptor

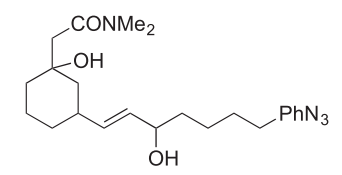

Aryl azide $\mathrm{LTB}_{4}$ derivative ' $4 \mathrm{~b} \alpha$ '

\section{TP receptor \\ Treceptor}

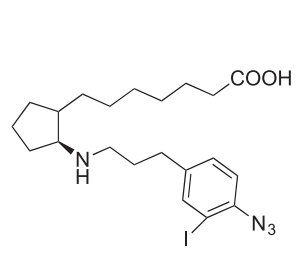

I-APA-PhN ${ }_{3}$<smiles>[R]CC(O)CNC1CC2CCC1CC2CC=CCCCC(=O)O</smiles>

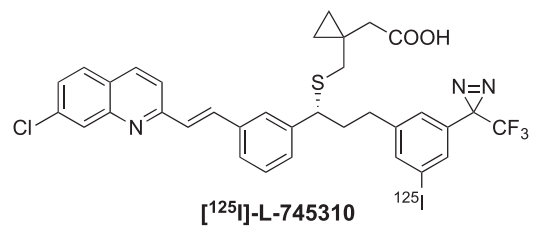

[125I]-L-745310

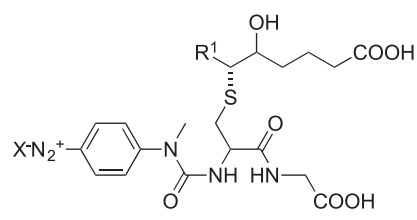

PAF receptor

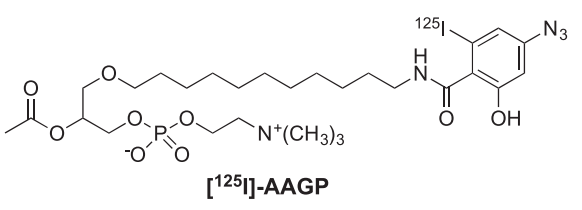

[125]]-AAGP

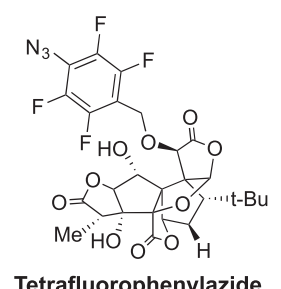

Tetrafluorophenylazide ginkgolide $B$ derivative $7 Z, 9 E \mathrm{LTD}_{4}$ aryldiazonium $\mathrm{R}^{1}=\mathrm{C}_{9} \mathrm{H}_{19}$ 7E,9E LTD $_{4}$ aryldiazonium
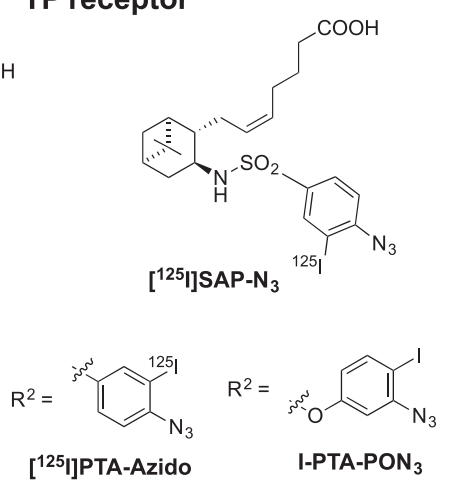

IP receptor

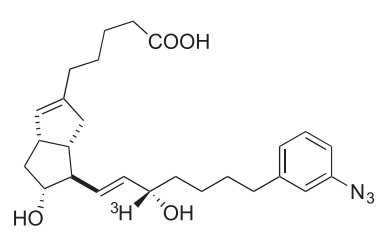

[ $\left.{ }^{3} \mathrm{H}\right]$ APNIC
EP receptor

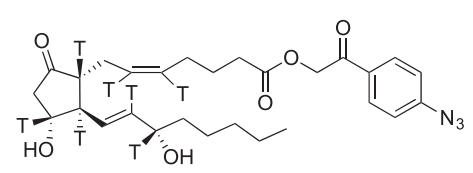

$\left[{ }^{3} \mathrm{H}\right]$ Azido-PGE 2 (T denotes $\left[{ }^{3} \mathrm{H}\right]$ )

Fig. 7. Leukotriene, PAF, and prostanoid receptor photoactivatable covalent tools.

$\mathrm{PGE}_{2}$ and azido-PGE $\mathrm{P}_{2}$. Another EP receptor photoaffinity probe has been reported, (15S)-17-(4-azidophenyl)18,19,20-trinorprostaglandin E2, which had moderate receptor affinity $\left(\mathrm{IC}_{50}=300 \mathrm{nM}\right.$ chicken spinal cord $\mathrm{EP}$ receptor), but covalent binding was not demonstrated (Kawada et al., 1991). A series of photoactivatable $\mathrm{PGF}_{2 \alpha}$ derivatives were synthesized with the purpose of developing an FP receptor probe. The highest affinity derivative in the series had a $K_{i}$ of $49 \mathrm{nM}$ (ovine luteal cells); however, covalent binding wasn't demonstrated (Golinski et al., 1992).

A number of other photoactivatable ligands have been developed for lipid-binding receptors that, due to lowmoderate affinity, will have limited utility as covalent tools, but may still have some application. For instance, labeling with moderate affinity aryl azide $\mathrm{LTB}_{4}$ derivative photoaffinity probe $4 \mathrm{~b} \alpha\left(\mathrm{IC}_{50}=0.7 \mu \mathrm{M}\right.$ at hLTB4 $4_{1}$ ) (Fig. 7; Table 4) was carried out in conjunction with amino acid sequencing and mass spectrometry to determine the binding residues as Cys 97, Ser 100, Met 101, and Ser 104 of TM-III and Trp 234 and Tyr 237 in TM-VI, providing initial characterization of the LTB4 1 receptor ligand binding site (Durand et al., 2000).

2. Electrophilic Covalent Ligands. A variety of reactive moieties has been used in covalent labels for class
A GPCRs, including isothiocyanates, halomethylketones, reactive thiols, Michael acceptors, and nitrogen mustards (Weichert and Gmeiner, 2015). The isothiocyanate is a popular choice for electrophilic tools as it is readily prepared from primary amines (Wong and Dolman, 2007), is stable in water, but is reactive with amino acids containing a thiol, imidazole, or amine under physiologic conditions (Guo et al., 1994).

AM708 and the closely related analog $7^{\prime}$-NCS-DMHTHC were the first two high-affinity electrophilic covalent ligands reported for $\mathrm{CB}_{1}$ receptor (Fig. 6; Table 4). Affinity of AM708 $\left(\mathrm{IC}_{50}=1.6 \pm 0.3 \mathrm{nM}\right.$ at $\left.\mathrm{rCB}_{1}\right)$ was measured with a $\left[{ }^{3} \mathrm{H}\right] \mathrm{CP}-55,940$ displacement assay (Guo et al., 1994). Treatment with $10 \mathrm{nM}$ AM708 led to $80 \%$ reduction in the available $\mathrm{rCB}_{1}$ receptor binding sites, whereas $100 \mathrm{nM}$ treatment practically depleted all the $\mathrm{rCB}_{1}$ receptor binding sites. Time- and AM708 concentration-dependent irreversible ligand-CB receptor binding was demonstrated for the first time. Guo et al. (1994) postulated that there must be an amine, thiol, or imidazole amino acid side chain present in the $\mathrm{CB}$ receptor binding site to which the covalent ligand bound. The more hydrophobic $7^{\prime}$-NCSDMH-THC $\left(\mathrm{IC}_{50}=0.66 \mathrm{nM}\right.$ at $\left.\mathrm{rCB}_{1}\right)$ demonstrated irreversible binding with incubation at five times the 
apparent $\mathrm{IC}_{50}$ leading to an $83 \%$ reduction in specific binding of $\left[{ }^{3} \mathrm{H}\right] \mathrm{CP}-55,940$ at $\mathrm{rCB}_{1}$ receptor (Morse et al., 1995). Taking all evidence into account, it was postulated that covalent binding of AM708 and 7'-NCSDMH-THC indicates the likelihood of a lysine or cysteine residue in proximity to the alkyl side chain terminus in the $\mathrm{CB}_{1}$ receptor-binding pocket (Picone et al., 2002). The CB receptor ligand AM960 (Fig. 6) $\left[\mathrm{IC}_{50}=25 \mathrm{nM}\right.$ at $\mathrm{rCB}_{1}$ (preliminary biologic experiment, no further full experiment reported)] was designed in an effort to introduce an iodo group while maintaining the covalent binding ability of AM708 (Chu et al., 2003). Incorporation of a C6 3-iodopropyne group was informed by previous SAR showing that an iodopropyl group at this position conferred high affinity and the iodo group offers potential for $\left[{ }^{125} \mathrm{I}\right]$ radiolabeling.

Concurrent use of covalent ligands and site-directed mutagenesis is a powerful way to study ligand-binding orientation and determine which amino acids are involved in binding of a specific ligand. AM841 (Fig. 6; Table 4) was the first $\mathrm{CB}_{1}$ receptor covalent tool to be used in conjunction with site-directed mutagenesis and provided important information about ligand activation sites (Picone et al., 2005). It was proposed using $\mathrm{CB}_{1}$ receptor homology modeling and ligand docking that a cysteine residue present on helix 6 C6.47 (residue 355), part of the highly conserved CWXP-binding motif in class A GPCRs, was the most likely site of covalent attachment of AM841. Mutation of Cys C6.47 to Ser, Ala, or Leu to reduce or eliminate the nucleophilicity of residue 355 was carried out to test this hypothesis. The affinity of AM841 for $\mathrm{hCB}_{1}$ C6.47 $\mathrm{Ser}\left(K_{\mathrm{i}}=10.46 \pm\right.$ $0.88 \mathrm{nM})$ and Ala $\left(K_{\mathrm{i}}=11.32 \pm 0.29 \mathrm{nM}\right)$ mutants was similar but was reduced for the C6.47 Leu mutant $\left(K_{\mathrm{i}}=\right.$ $58.09 \pm 11.69 \mathrm{nM})$. In spite of retaining some receptor affinity, AM841 did not irreversibly bind to any of the three mutants. It is therefore worth considering the contribution of measured binding affinity versus covalent bond formation-high ligand affinity is not dependent on covalent bond formation, although measurement can be biased depending on the experiment used to measure $K_{\mathrm{i}}$. Also of consideration is the effect site-directed mutagenesis has on overall receptor shape/misfolding. In this study, the $\mathrm{CB}_{1}$ receptor global conformation of the mutants is likely to be maintained as it is in the wild-type receptor because AM841 displayed comparable affinity.

There have been multiple studies utilizing AM841 to probe $\mathrm{CB}$ receptor structure and function. Pei et al. (2008) used AM841 to demonstrate distinctions in ligand-binding motifs between $\mathrm{hCB}_{1}$ and $\mathrm{hCB}_{2}$ receptor subtypes via complementary site-directed mutagenesis and ligand-docking studies. Mutagenesis of $\mathrm{hCB}_{2}$ receptor indicated that $\mathrm{C} 6.47$ is the site of covalent attachment of AM841 and ruled out two cysteines on helix seven, C7.38 and C7.42. Activation of $\mathrm{hCB}_{2}$ receptor by AM841 (leading to inhibition of forskolin- stimulated cAMP production) was achieved with much higher potency compared with the noncovalent analog of AM841 (wherein the NCS group is replaced by an $\mathrm{H}$ atom) or at $\mathrm{hCB}_{1}$ receptor. The highly conserved $\mathrm{CB}_{1}$ receptor Lys K3.28, which has been shown to be important in recognition of multiple ligands by $\mathrm{hCB}_{1}$ receptor (Song and Bonner, 1996), was demonstrated as having little effect on $\mathrm{hCB}_{2}$ receptor-AM841 binding. Pei et al. (2008) also postulated that AM841 accesses the $\mathrm{CB}_{2}$ receptor-binding pocket through the lipid bilayer (discussed in Leukotriene Receptor). Despite a potential lipid bilayer entry, covalent ligands such as AM841 are thought unlikely to bind to random nucleophilic amino acids as a high-affinity binding interaction needs to occur before significant covalent labeling can occur. This specific covalent reactivity can be shown using mass spectrometry, as demonstrated by Szymanski et al. (2011), who further characterized the covalent interaction of $\mathrm{AM} 841$ with $\mathrm{hCB}_{2}$ receptor residue C6.47. Multiple reaction mass spectrometry monitoring showed that covalent modification of $\mathrm{hCB}_{2}$ receptor by AM841 was exclusive to TMH6, and high-resolution mass spectrometry of the TMH6 tryptic peptide confirmed this covalent labeling to be selective for C6.47 (Szymanski et al., 2011). This report shows the power of combining mass spectrometry-based proteomics and site-directed covalent labeling in the elucidation of GPCR ligand binding sites. Taken together, this information provides valuable insight into $\mathrm{CB}$ receptor ligand-binding pocket(s) and requirements for high-affinity, selective ligand design.

Highly specific and potent covalent ligands have also been used to investigate the physiologic and pathophysiological roles of GPCRs. AM841 has been used in an in vivo study of inflammatory bowel disease to show the involvement of both central and peripheral $\mathrm{mCB}_{1}$ and $\mathrm{mCB}_{2}$ receptors in the anti-inflammatory action of cannabinoids (Fichna et al., 2014). The utility of AM841 in research and therapeutics has been further demonstrated by examining gastrointestinal motility in healthy and stressed mice (Keenan et al., 2015). In this study, AM841 was found to act as a peripherally restricted ligand, normalizing accelerated gastrointestinal motility through action on $\mathrm{CB}_{1}$ receptor in the small and large intestine. These studies demonstrate the therapeutic potential of covalent ligands such as AM841. It would be interesting to see what the equivalent noncovalent ligand would do in the same experiments to dissect the importance of the covalent attachment in the observed therapeutic effects.

An electrophilic adamantyl-substituted covalent tool (AM994) (Fig. 6; Table 4) has also been developed with good affinity for both $\mathrm{CB}_{1}$ and $\mathrm{CB}_{2}$ receptors, which behaved as an agonist at $\mathrm{rCB}_{1}$ receptor and an inverse agonist at $\mathrm{hCB}_{2}$ receptor (Ogawa et al., 2015). Successful labeling of $\mathrm{CB}$ receptor following pretreatment with 10 -fold the $K_{\mathrm{i}}$ of AM994 was demonstrated with a $63 \%$ 
reduction in specific binding of $\left[{ }^{3} \mathrm{H}\right] \mathrm{CP}-55,940$ at $\mathrm{rCB}_{1}$ receptor and a $74 \%$ reduction at $\mathrm{hCB}_{2}$ receptor.

The same research group that developed photoactivatable AM3661 has also synthesized an isothiocyanatefunctionalized AEA tool AM3677 (Fig. 6; Table 4), which irreversibly labels $58 \%$ of $\mathrm{rCB}_{1}$ receptor when used at $26 \mathrm{nM}$ (binding assays carried out in presence of serine protease inhibitor as with AM3661) (Li et al., 2005). Further structural and functional profiling was carried out by Janero et al. (2015), which showed that AM3677 forms a covalent bond to $\mathrm{hCB}_{1} \mathrm{C} 6.47$. AM3677 was found to function as an agonist, inhibiting cellular cAMP formation and stimulating irreversible internalization of $\mathrm{rCB}_{1}$ receptor. The authors propose AM3677 could be used as a tool in the study of ECB-induced $\mathrm{CB}_{1}$ receptor activation and associated signaling.

Functionalization of a known biarylpyrazole (AM6731) with an isothiocyanate group generated AM1336 (Fig. 6; Table 4), a covalent $\mathrm{hCB}_{2}$ receptor inverse agonist (Mercier et al., 2010). AM1336 irreversibly bound 60\% of available $\mathrm{hCB}_{2}$ receptor when administered at $5.4 \mathrm{nM}$. Mutation of Cys to Ala or Ser at single and multiple points in $\mathrm{hCB}_{2}$ receptor and analysis using tool AM1336 revealed two residues in TMH7 (C7.38 residue 284 and C7.42 residue 288) as key for inverse agonist binding. C1.39 (residue 40) of TMH1 was also found to modulate $\mathrm{hCB}_{2}$ receptor ligand affinity, and residue C137 from intercellular loop 2 was shown to affect the maximum efficacy of AM1336.

Exploration of the aminoalkylindole CB chemical scaffold as an electrophilic ligand has been carried out with synthesis of analogs containing an isothiocyanate on the indole ring or at various C3 naphthyl positions (Yamada et al., 1996). The most potent derivative (isothiocyanate 12) (Fig. 6; Table 4), containing indole 6 -isothiocyanate substitution, demonstrated irreversible binding at sixfold the $\mathrm{IC}_{50}$ with $70 \%$ reduction in specific binding of $\left[{ }^{3} \mathrm{H}\right] \mathrm{CP}-55,940$ at $\mathrm{rCB}_{1}$ receptor. This depletion of $\left[{ }^{3} \mathrm{H}\right] \mathrm{CP}-55,940$ binding indicates that the aminoalkylindole class and nonclassic CBs (e.g., CP-55,940) may have overlapping binding sites.

Due to the psychotropic side effects associated with direct $\mathrm{CB}_{1}$ receptor activation, alternative $\mathrm{CB}$ drug development strategies have been investigated. One area of promise is allosteric modulators, potentially allowing more efficacious control of downstream signaling effects. However, improved knowledge of any $\mathrm{CB}_{1}$ receptor allosteric site(s) is critical to drug development. To this end, Kulkarni et al. (2016) have recently developed the covalent $\mathrm{CB}_{1}$ receptor ligand GAT100 (Fig. 6 ; Table 4), by replacement of the chloro moiety of allosteric $\mathrm{CB}_{1}$ receptor allosteric ligand ORG27569 (Fig. 6) with an isothiocyanate group. Further in-depth characterization showed GAT100 is a negative allosteric modulator of CP-55,940 (Fig. 1), AEA, and 2-AG across several signaling pathways and may interact with key residue $\mathrm{C} 7.38(382)$ of $\mathrm{CB}_{1}$ receptor (Laprairie et al., 2016). It will be very interesting to see what structural knowledge of the $\mathrm{CB}_{1}$ receptor allosteric site is gleaned by future use of this tool.

Methyl arachidonyl fluorophosphonate has been shown to act as an irreversible inhibitor of $\mathrm{CB}_{1}$ receptor $\left(\mathrm{IC}_{50}=\right.$ $20 \mathrm{nM}$ at $\mathrm{rCB}_{1}$ ) (Fig. 6; Table 4), preventing subsequent binding of CP-55,940 and reducing the maximal responses of agonists WIN 55,212-2 and CP-55,940 (Deutsch et al., 1997; Fernando and Pertwee, 1997). Methyl arachidonyl fluorophosphonate, which is also a potent irreversible antagonist of FAAH $\left(\mathrm{IC}_{50}=2.5 \mathrm{nM}\right.$ at rFAAH $)$, acts as a phosphonylation agent as the electrophilic fluorophosphonate group can covalently label nucleophilic residues such as serine.

There is a lack of electrophilic covalent probes for the other fatty acid-binding class A GPCRs when compared with CB receptors. An attempt at an electrophilic covalent ligand for the putative prostamide receptor(s) was made; however, biologic data have not yet been published (Shelnut et al., 2015).

3. Bifunctional Covalent Ligands. Bifunctional ligands with two reactive/photoactivatable functional groups are capable of forming two covalent bonds to one receptor. To this end, the homobifunctional ligand AM5823 with two isothiocyanate groups and the heterobifunctional ligand AM5822 with an isothiocyanate and an azide group have been developed (Fig. 7) (unpublished data) (Makriyannis, 2014). Another bifunctional tool, di-azido AM859, has been reported in a review $\left(K_{\mathrm{i}}=1.6 \mathrm{nM}\right.$ at $\mathrm{CB}_{1}, 2.65 \mathrm{nM}$ at $\left.\mathrm{CB}_{2}\right)$ (unpublished primary experimental data) (Khanolkar et al., 2000). It is hoped that this approach will provide greater spatial accuracy in the classification of $\mathrm{CB}$ receptor ligandbinding orientation.

\section{Antibodies}

An antibody (or immunoglobulin) is a heterodimer glycoprotein consisting of two amino acid heavy chains and two light chains linked by disulfide bonds and hydrophobic interactions (Schroeder and Cavacini, 2010). These chains contain a constant sequence region at the C-terminal and a variable sequence region at the $\mathrm{N}$-terminal, the latter of which selectively binds to a particular antigen. Significant obstacles to raising antibodies against membrane-embedded GPCRs include low receptor expression levels and the difficulty in isolating pure receptor in a stable and functionally relevant conformation (Hutchings et al., 2010). Methods are being developed to improve stability and overexpress GPCRs to aid in the production of functional antibodies (for example (Takeda et al., 2015)).

\section{A. Characteristics of Antibodies}

Antibodies from a monoclonal source (mAbs) are identical, as they are produced by a single clone of a $\mathrm{B}$ cell hybridoma and bind to a single epitope. Polyclonal 
antibodies (pAbs) are produced by multiple B lymphocytes and thus are a mix of antibodies with varying affinity and specificity (Ritter, 2000). GPCRs exhibit a high degree of conformational flexibility (particularly in the extracellular loops), and this can impact antibody affinity if an epitope is more or less accessible in a particular conformer (Peeters et al., 2011). The affinity of a mAb toward a GPCR may also be sensitive to receptor conformation, polymorphism, and/or glycosylation state. The affinity of pAbs may be less affected by receptor conformation; however, there may be less specificity for GPCRs compared with mAbs (Lipman et al., 2005), and there can be batch to batch variability. Overall, the affinity, specificity, and reproducibility of mAbs over pAbs are hugely advantageous in the pursuit of reliable and consistent results (Singh et al., 2014).

\section{B. Antibody Limitations}

The major limitations with using antibodies as tools for GPCR localization studies are false positives and false negatives. False positives most often occur due to lack of antibody specificity, leading to the recognition of other proteins with similar or identical epitopes (Ivell et al., 2014). False negatives can likewise arise due to low antibody specificity for the target, but can also be caused by epitopes being hidden or in an altered conformation, or by unsuitable sample fixing procedures. In addition, use of antibodies can be especially challenging and unreliable in the study of GPCRs due to very low levels of receptor expression.

$\mathrm{CB}_{1}$ receptor is historically regarded as the $\mathrm{CNS} \mathrm{CB}$ receptor, whereas $\mathrm{CB}_{2}$ receptor is the peripheral receptor. Reports of neuronal $\mathrm{CB}_{2}$ receptor using antibodybased methods have challenged this notion (reviewed in Atwood and Mackie, 2010); however, there has long been debate in the $\mathrm{CB}$ receptor community surrounding the accuracy of reported receptor expression determined solely using antibodies. This fueled a spate of $\mathrm{CB}_{2}$ receptor antibody validation studies (Baek et al., 2013; Cecyre et al., 2014; Marchalant et al., 2014), which showed that whereas many commercially available pAbs have sensitivity for $\mathrm{CB}_{2}$ receptors, often specificity is lacking. Other validation studies have also raised doubts of the specificity of several $\mathrm{CB}_{1}$ receptor pAbs (Grimsey et al., 2008; Morozov et al., 2013), as well as a $\mathrm{S}_{1} \mathrm{P}_{1}$ receptor $\mathrm{mAb}$ and $\mathrm{pAb}$ (Talmont and Moulédous, 2014) and a FFA1 receptor mAb and two pAbs (Teutsch et al., 2014). Together, these validation studies illustrate the importance of complete characterization of tools for the individual applications intended. There are many positive and negative controls available for accurate confirmation of antibody specificity, and these are summarized well elsewhere (Rhodes and Trimmer, 2006; Moser et al., 2007; Bussolati and Leonardo, 2008; Lorincz and Nusser, 2008; Baek et al., 2013).

Antibodies can be purchased from a commercial source or made in-house; however, each option has limitations. Specificity of commercial mAbs and pAbs has been shown to be highly variable (Berglund et al., 2008), so time-consuming, thorough validation of the antibody is necessary to ensure meaningful results. It has been estimated that poor characterization of antibodies costs biomedical research $\$ 350$ million each year in the United States (Bradbury and Pluckthun, 2015). Some academic groups produce their own antibodies to reliably secure sufficient reagent to complete their study, but this can be expensive and time consuming, with no guarantee of a functioning antibody (Rhodes and Trimmer, 2006). Reproducibility of antibody-based experiments is hampered by an estimated $44 \%$ of published articles (in all fields of research) failing to provide enough unique identifiers of the antibody used (i.e., a universal database identifier, or a vendor and catalog number, or protocols for reproduction) (Vasilevsky et al., 2013). There are numerous CB, FFA, S1P, LPA, prostanoid, leukotriene, PAF, and GPBA receptor antibodies available for purchase and a number of comprehensive databases available that detail some of these antibodies (http://www.antibodypedia.com/, http://antibodyregistry. org/ and https://www.citeab.com/). Only the specific details of the antibodies used in the examples cited have been given in this work.

\section{Applications of Antibodies}

Antibodies have been used to detect and quantify lipidbinding receptors using a variety of techniques such as Western blotting, immunohistochemistry (IHC), immunocytochemistry, flow cytometry, and immunofluorescence. Antibodies have been used to study localization and variation in receptor expression between different tissue types and disease states. Antibodies can be used in conjunction with radioligands to help identify structural motifs key to function, for example, C-EL2Ab and $\left[{ }^{3} \mathrm{H}\right]$ SQ-29548 described in Applications of Radioligands (Murad et al., 2012). Several recent examples are discussed in this review that demonstrate a range of techniques rather than an exhaustive summary, as the number of studies is extensive.

IHC is commonly used to study CB receptor expression across different cell and tissue types (Bouskila et al., 2013), between healthy and diseased tissue (Allen et al., 2009; Dowie et al., 2014), and in developing predictions of disease severity and outcome (Chung et al., 2009). IHC has also been used to localize GPBA receptor expression (Cipriani et al., 2013), to study CysLT $_{1}$ receptor expression in Hodgkin's lymphoma (Schain et al., 2008), and to localize $\mathrm{EP}_{1}, \mathrm{EP}_{2}, \mathrm{EP}_{3}, \mathrm{EP}_{4}$, and $\mathrm{FP}$ receptor expression in the human ureter (Oll et al., 2012).

Western blotting has been used to study variations in CB receptor expression (Alvaro-Bartolome and GarciaSevilla, 2013). IHC and Western blotting have been used to localize FFA1 and FFA4 receptor (Mizuta et al., 2015), FFA3 receptor (Nøhr et al., 2015), and ${\mathrm{S} 1 \mathrm{P}_{1}}$ receptor expression (Bradaric et al., 2011; Maeda et al., 
2014). Using antibodies, localization of elevated $\mathrm{S}_{1} \mathrm{P}_{1}$ receptor helped demonstrate that the $\mathrm{BBB}$-protective effects of the traditional antimalarial drug artesunate are mediated through $\mathrm{S}_{1} \mathrm{P}_{1}$ receptor signaling (Zuo et al., 2017). In another study, Western blotting and immunocytochemistry were used to show that activation of S1P receptor induces cardiac hypertrophy (Robert et al., 2001). IHC and LPA receptor antibodies have been used as tools to study tissue expression of LPA receptors, for example, on cell membranes in muscle-invasive bladder cancer specimens (where greater $\mathrm{LPA}_{1}$ receptor expression was observed), indicating this could be used as a diagnostic marker (Kataoka et al., 2015).

Machado et al. (2014) used immunofluorescence to monitor $\mathrm{CB}$ receptor activation in rat paw using fluorescently labeled $\mathrm{CB}_{1}$ and $\mathrm{CB}_{2}$ receptor antibodies (Proteimax Biotechnology, Cotia, São Paulo, Brazil) that are specific to the activated receptor conformation. This study monitored CB and opioid receptor interactions during treatment with the snake venom peptide crotalphine, concluding that the venom antinociceptive effects were dependent on activation of peripheral $\mathrm{CB}_{2}$ receptor, causing release of dynorphin $\mathrm{A}$ and subsequent $\kappa$-opioid receptor activation. Immunofluorescence labeling has been used to investigate FFA1 receptor in the medulla oblongata in a study of the role that this receptor plays in pain control mechanisms (Nakamoto et al., 2015). Immunofluorescence has also been used to study $\mathrm{EP}_{4}$ receptor expression in an investigation evaluating the potential of this receptor as a therapeutic target for leukemia and lymphoma (Gobec et al., 2014).

Flow cytometry has been used by Jean-Gilles et al. (2015) to quantify fluorescent antibody (PA1-745 and PA1-744; Affinity Bioreagents, Golden, CO) labeling of $\mathrm{CB}_{1}$ and $\mathrm{CB}_{2}$ receptors in the presence of proinflammatory cytokines in MS (Jean-Gilles et al., 2015). Agudelo et al. (2013) also used flow cytometry and primary polyclonal and secondary fluorescein-conjugated antibodies (sc-20754 and sc-25494, Santa Cruz Biotechnology, Santa Cruz, CA; 10224, Cayman Chemicals, Ann Arbor, MI, respectively) to quantify $\mathrm{CB}_{1}, \mathrm{CB}_{2}$ receptor, and GPR55 to study the effects of alcohol use on immune responses and dendritic cell modulation. This study concluded that alcohol upregulated $\mathrm{CB}_{2}$ receptor and GPR55 in monocyte-derived dendritic cells. IHC and flow cytometry were used to study how variations in anatomic location of B cell non-Hodgkin's lymphoma can be related to the differential expression of $\mathrm{S}_{1} \mathrm{P}_{1}$ and $\mathrm{S}_{1} \mathrm{P}_{3}$ receptors (both which control lymphocyte exit from secondary lymphoid organs) and $\mathrm{S}_{1} \mathrm{P}_{2}$ receptor (responsible for retention of lymphocytes within germinal centers) (Middle et al., 2015). Flow cytometry was used to investigate reduced LTB4 $4_{1}$ receptor expression in chronic myeloid leukemia patients (Lucas et al., 2014) and increased $\mathrm{LTB}_{2}$ receptor expression in a study on cisplatin-resistant ovarian cancer (Park et al., 2016).
Antibodies labeled with a heavy metal, most commonly gold, can be studied using electron microscopy. For example, the role of $\mathrm{CB}_{1}$ receptor in epilepsy and neurodegenerative disease was examined by labeling

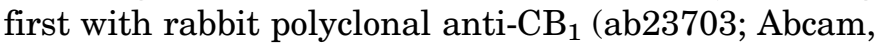
Cambridge, UK) and then with goat anti-rabbit IgG conjugated to 1.4-nm gold grains (Nanoprobes, Stony Brook, NY) (Meng et al., 2014). Observations by electron microscopy demonstrated that $\mathrm{CB}_{1}$ receptor expression was enhanced in the astrocytes of epileptic rats. Heterodimerization of GPCRs can have significant effects on receptor function, signaling and trafficking, and ligand pharmacology (Hiller et al., 2013). GPCR heterodimer-selective antibodies have been used to study the localization, prevalence, and function of GPCR heteromers (reviewed in Gomes et al., 2014). A mAb specific for $\delta$ opioid- $\mathrm{CB}_{1}$ receptor heteromers was used by Bushlin et al. (2012) to detect increased $\delta$ opioid- $-\mathrm{CB}_{1}$ heteromer prevalence in the cortex upon induction of neuropathic pain. This study also found nonsignaling doses of $\mathrm{CB}_{1}$ receptor agonists increased $\delta$ opioid receptor activity in neuropathic pain-afflicted animals ex vivo. The antibody was capable of blocking this heteromermediated activity, thus demonstrating the potential of heteromer-selective antibodies as therapeutic agents and $\delta$ opioid- $-\mathrm{CB}_{1}$ heteromer as a therapeutic target. In another study, an antibody selective for the $\mathrm{CB}_{1}-\mathrm{AT}_{1}$ receptor heteromer was used to investigate heteromermediated signaling (Rozenfeld et al., 2012). Production of fibrogenic proteins from activated hepatic stellate cells in alcohol-treated rat membranes was blocked by the heteromer-specific antibody, indicating the potential of $\mathrm{CB}_{1}-\mathrm{AT}_{1}$ heteromers as a therapeutic target for liver fibrosis therapies. However, it is important to note that the results from these studies were observed in vitro, and that there will be additional challenges in the therapeutic application of antibodies in the CNS, such as BBB penetrability. Strategies are in development for improving antibody brain penetration (Niewoehner et al., 2014) as well as the design of small-molecule bivalent ligands that target receptor heteromers.

\section{Beyond Antibodies}

Many GPCR antibody limitations such as selectivity, stability, solubility, and production are being addressed by the emergence of the next generation of tools. For example, bio-orthogonal coupling and release of either a drug or tracer to an antibody that targets tumorassociated glycoproteins have been demonstrated (Rossin et al., 2016). This approach has yet to be reported for antibodies targeting GPCRs, although no doubt will be reported in the future. Nanobodies are single-domain antibodies approximately $10 \%$ of the size of regular antibodies that have two heavy and two light chains. Nanobodies are increasingly used as diagnostics, targeting tools, and therapies (reviewed in De Meyer et al., 2014 and Chakravarty et al., 2014), and for GPCRs have 
been useful for cocrystallization and X-ray structure determination, for example, stabilizing $\beta_{2}$-adrenergic receptor in the active form (Ring et al., 2013). More recently, a negative allosteric nanobody for $\beta_{2}$-adrenergic receptor has been reported and used to tease out the pharmacology of various ligands (Staus et al., 2016). Affibodies are smaller nonimmunoglobulin proteins that are increasingly used as both diagnostic tools and drugs (Feldwisch et al., 2012). Bio-orthogonal pretargeting followed by coupling of fluorophores and in vivo radioligands to an affibody that targets human epidermal growth factor receptor 2 has been reported (Altai et al., 2016). To date nanobodies or affibodies for CB, FFA, $\mathrm{LPA}$, or S1P receptors have not been reported.

\section{Conclusions and Future Outlook}

The discovery and characterization of CB, FFA, LPA, S1P, prostanoid, leukotriene, GPBA, and PAF receptors have been made possible by the use of tools such as covalent and fluorescent small-molecule ligands, radioligands, and antibodies. An ideal tool or technique should be able to provide information about the chemical and conformational structure of the receptor, changes occurring during receptor activation, and receptorsignaling cascades in the native cell environment. However, it is difficult to imagine a single tool or technique capable of providing all this information in a system as complex as GPCRs. Thus, our current understanding of receptor structure and function is based on information obtained using these tools in conjunction with other techniques such as molecular biology and receptor mutagenesis, X-ray crystallography, and homology modeling. Before the application of an individual tool to study a receptor, it is critical that the tool be subjected to rigorous pharmacological validation, as structural modifications can drastically alter the pharmacological characteristics in comparison with the untagged/unmodified ligand.

Radioligands, including those based on synthetic scaffolds reviewed in this work and also radiolabeled endogenous ligands, are the most developed tools for all the lipid-binding class A GPCRs. Preclinical in vivo imaging, in particular for $\mathrm{CB}_{1}$ receptor, is increasingly used where signal depth/tissue penetration is a consideration. Radioligands have the advantage of sharing the highest structural similarity with the parent ligand as compared with other tools and cause minimum disturbance compared with the unlabeled ligand-receptor interaction. However, the drawbacks of radiation safety and shelf life fuel the continued development and interest in small-molecule fluorescent tools. Future development of synthetic ligands tethered to newly discovered NIR fluorophores will fuel the use of fluorescent probes for in vivo imaging as an alternative to radioligands, especially as longer wavelength NIR-II fluorophores allow for improved detection depth.
Although there can be issues with nonspecific background fluorescence and quenching by fluorescence chelators, the advantages of small-molecule fluorescent ligands (such as precise spatial information) usually far exceed these limitations. Nonspecific membrane interactions can be an issue for radioligands and fluorescent ligands, especially when the core pharmacophore/ligand is hydrophobic, as is often the case for lipid-binding GPCRs. A nonspecific membrane interaction is very much probespecific, so researchers should select the best available tool for their experiment hypothesis, or alternatively there are huge scope and demand to design and synthesize novel probes with more favorable properties. Covalent ligands are powerful tools to probe the binding site of these lipid receptors especially when used in conjunction with mutation studies. Antibodies are very versatile and can be used in a number of different techniques and are theoretically very specific, yet the cost, pharmacokinetic properties (especially for in vivo study), and the questions surrounding specificity (in particular for $\mathrm{CB}_{2}$ receptor antibodies) are limiting factors.

The toolbox available to researchers for some lipidreceptor subtypes is either empty or minimal. As drug discovery drives reports of new high-affinity selective small-molecule ligands, it is anticipated this in turn will facilitate development of new chemical tools with better selectivity and pharmacokinetic properties.

Continued advancement of knowledge regarding GPCR structure and ligand-receptor binding interactions, such as that provided by the recently solved $\mathrm{CB}_{1}$ receptor crystal structures, will also fuel rational design of chemical tools. The use of biologics as selective tools is another expanding field, with researchers focusing on smaller ligands such as peptides, nanobodies, affibodies, and aptamers. Development of new tools will enable probing questions about CB, FFA, LPA, and S1P receptors to be addressed, in particular in complex processes such as receptor allosterism and oligomerization.

\section{Acknowledgments}

We thank the School of Pharmacy and the University of Otago for doctoral scholarships for A.C. and S.S.

\section{Authorship Contributions}

Wrote or contributed to the writing of the manuscript: Cooper, Singh, Hook, Tyndall, Vernall.

\section{References}

Abdel-Latif A, Heron PM, Morris AJ, and Smyth SS (2015) Lysophospholipids in coronary artery and chronic ischemic heart disease. Curr Opin Lipidol 26:432-437. Abramovitz M, Adam M, Boie Y, Carrière M, Denis D, Godbout C, Lamontagne S, Rochette C, Sawyer N, Tremblay NM, et al. (2000) The utilization of recombinant prostanoid receptors to determine the affinities and selectivities of prostaglandins and related analogs. Biochim Biophys Acta 1483:285-293.

Agudelo M, Yndart A, Morrison M, Figueroa G, Muñoz K, Samikkannu T, and Nair MP (2013) Differential expression and functional role of cannabinoid genes in alcohol users. Drug Alcohol Depend 133:789-793.

Agurell S, Nilsson IM, Ohlsson A, and Sandberg F (1969) Elimination of tritiumlabelled cannabinols in the rat with special reference to the development of tests for the identification of cannabis users. Biochem Pharmacol 18:1195-1201.

Ahamed M, Verbruggen A, and Bormans G (2013) Synthetic strategies for radioligands for in vivo imaging of brain cannabinoid type-1 receptors. J Labelled Comp Radiopharm 56:207-214. 
Aharony D, Falcone RC, Yee YK, Hesp B, Giles RE, and Krell RD (1988) Biochemical and pharmacological characterization of the binding of the selective peptideleukotriene antagonist, ${ }^{3} \mathrm{H}$-ICI 198,615 , to leukotriene $\mathrm{D}_{4}$ receptors in guinea-pig lung membranes. Ann N Y Acad Sci 524:162-180.

Ahmad R, Goffin K, Van den Stock J, De Winter FL, Cleeren E, Bormans G, Tournoy J, Persoons P, Van Laere K, and Vandenbulcke M (2014) In vivo type 1 cannabinoid receptor availability in Alzheimer's disease. Eur Neuropsychopharmacol 24:242-250.

Ahmad R, Koole M, Evens N, Serdons K, Verbruggen A, Bormans G, and Van Laere K (2013) Whole-body biodistribution and radiation dosimetry of the cannabinoid type 2 receptor ligand $\left[{ }^{11} \mathrm{C}\right]-\mathrm{NE} 40$ in healthy subjects. Mol Imaging Biol 15:384-390.

Allen KL, Waldvogel HJ, Glass M, and Faull RL (2009) Cannabinoid $\left(\mathrm{CB}_{1}\right)$ ), GABA $\left.{ }_{A}\right)$ and $\left.\mathrm{GABA}_{\mathrm{B}}\right)$ receptor subunit changes in the globus pallidus in Huntington's disease. $J$ Chem Neuroanat 37:266-281.

Altai M, Perols A, Tsourma M, Mitran B, Honarvar H, Robillard M, Rossin R, ten Hoeve W, Lubberink M, Orlova A, Karlström AE, and Tolmachev V (2016) Feasibility of Affibody-Based Bioorthogonal Chemistry-Mediated Radionuclide Pretargeting. J Nucl Med. 57:431-436.

Alvarez-Curto E and Milligan G (2016) Metabolism meets immunity: the role of free fatty acid receptors in the immune system. Biochem Pharmacol 114:3-13.

Álvaro-Bartolomé M and García-Sevilla JA (2013) Dysregulation of cannabinoid $\mathrm{CB}_{1}$ receptor and associated signaling networks in brains of cocaine addicts and cocaine-treated rodents. Neuroscience 247:294-308.

Arish M, Husein A, Kashif M, Saleem M, Akhter Y, and Rub A (2016) Sphingosine-1phosphate signaling: unraveling its role as a drug target against infectious diseases. Drug Discov Today 21:133-142.

Armstrong RA, Humphrey PPA, and Lumley P (1993) Characteristics of the binding of $\left[{ }^{3} \mathrm{H}\right]$-GR32191 to the thromboxane (TP-) receptor of human platelets. $\mathrm{Br} J$ Pharmacol 110:539-547.

Arora SK, Kattelman EJ, Lim CT, Le Breton GC, and Venton DL (1987) Preparation and biological evaluation of a potential photoaffinity label for the prostaglandin $\mathrm{H}_{2} /$ thromboxane $\mathrm{A}_{2}$ receptor. J Med Chem 30:918-924.

Atwood BK and Mackie K $(2010) \mathrm{CB}_{2}$ : a cannabinoid receptor with an identity crisis. Br J Pharmacol 160:467-479.

Bäck M, Dahlén SE, Drazen JM, Evans JF, Serhan CN, Shimizu T, Yokomizo T, and Rovati GE (2011) International Union of Basic and Clinical Pharmacology. LXXXIV: leukotriene receptor nomenclature, distribution, and pathophysiological functions. Pharmacol Rev 63:539-584.

Bäck M, Powell WS, Dahlén SE, Drazen JM, Evans JF, Serhan CN, Shimizu T, Yokomizo T, and Rovati GE (2014) Update on leukotriene, lipoxin and oxoeicosanoid receptors: IUPHAR Review 7. Br J Pharmacol 171:3551-3574.

Baek J-H, Darlington CL, Smith PF, and Ashton JC (2013) Antibody testing for brain immunohistochemistry: brain immunolabeling for the cannabinoid $\mathrm{CB}_{2}$ receptor. $J$ Neurosci Methods 216:87-95.

Bai M, Sexton M, Stella N, and Bornhop DJ (2008) MBC94, a conjugable ligand for cannabinoid $\mathrm{CB}_{2}$ receptor imaging. Bioconjug Chem 19:988-992.

Barbaro JF and Zvaifler NJ (1966) Antigen induced histamine release from platelets of rabbits producing homologous PCA antibody. Proc Soc Exp Biol Med 122:1245-1247.

Bayewitch M, Avidor-Reiss T, Levy R, Barg J, Mechoulam R, and Vogel Z (1995) The peripheral cannabinoid receptor: adenylate cyclase inhibition and $\mathrm{G}$ protein coupling. FEBS Lett 375:143-147.

Berglund L, Björling E, Oksvold P, Fagerberg L, Asplund A, Szigyarto CA, Persson A, Ottosson J, Wernérus H, Nilsson P, et al. (2008) A genecentric Human Protein Atlas for expression profiles based on antibodies. Mol Cell Proteomics 7:2019-2027.

Berthelette C and Wang Z (2007) Practical $\left[{ }^{14} \mathrm{C}\right]$-synthesis of molecules containing an acetic acid moiety: application to $\left[{ }^{14} \mathrm{C}\right]$-labeled DP1 antagonists. J Labelled Comp Radiopharm 50:1-5.

Bertrand R, Hamp I, Brönstrup M, Weck R, Lukacevic M, Polyak A, Ross TL, Gotthardt $\mathrm{M}$, Plettenburg O, and Derdau V (2016a) Synthesis of GPR40 targeting ${ }^{3} \mathrm{H}$ - and ${ }^{18} \mathrm{~F}$ probes towards selective beta cell imaging. J Label Compd Radiopharm. 59: 604-610.

Bertrand R, Wolf A, Ivashchenko Y, Löhn M, Schäfer M, Brönstrup M, Gotthardt M, Derdau V, and Plettenburg O (2016b) Synthesis and characterization of a promising novel FFAR1/GPR40 targeting fluorescent probe for $\beta$-cell imaging. ACS Chem Biol 11:1745-1754

Bhosle VK, Rivera JC, Zhou TE, Omri S, Sanchez M, Hamel D, Zhu T, Rouget R, Rabea AA, Hou X, et al. (2016) Nuclear localization of platelet-activating factor receptor controls retinal neovascularization. Cell Discov 2:16017.

Bigott-Hennkens HM, Dannoon S, Lewis MR, and Jurisson SS (2008) In vitro receptor binding assays: general methods and considerations. Q J Nucl Med Mol Imaging 52:245-253.

Birke F and Stiasni M (1989) inventors, Boehringer Ingelheim Kg, assignee. Radioactively labeled platelet-activating factor antagonist WEB 2086 Patent DE3725130 A1. 31 Jul 1986.

Blaho VA and Hla T (2014) An update on the biology of sphingosine 1-phosphate receptors. J Lipid Res 55:1596-1608.

Bornhop DJ, Bai M, Stella N, and Stern E (2013) inventors. Cannabinoid receptor targeted agent. U.S. patent 8,367,714 B2. Vanderbilt University, University of Washington assignee, publication date 5 Feb 2013.

Bosier B, Muccioli GG, Hermans E, and Lambert DM (2010) Functionally selective cannabinoid receptor signalling: therapeutic implications and opportunities. Biochem Pharmacol 80:1-12.

Bouaboula M, Bourrié B, Rinaldi-Carmona M, Shire D, Le Fur G, and Casellas P (1995) Stimulation of cannabinoid receptor CB1 induces krox-24 expression in human astrocytoma cells. J Biol Chem 270:13973-13980.

Bouskila J, Javadi P, Casanova C, Ptito M, and Bouchard J-F (2013) Müller cells express the cannabinoid CB2 receptor in the vervet monkey retina. J Comp Neurol 521:2399-2415.

Bousser MG, Amarenco P, Chamorro A, Fisher M, Ford I, Fox KM, Hennerici MG, Mattle HP, Rothwell PM, de Cordoüe A, et al.; PERFORM Study Investigators (2011) Terutroban versus aspirin in patients with cerebral ischaemic events (PERFORM): a randomised, double-blind, parallel-group trial. Lancet 377:2013-2022.
Bradaric MJ, Barua A, Penumatsa K, Yi Y, Edassery SL, Sharma S, Abramowicz JS, Bahr JM, and Luborsky JL (2011) Sphingosine-1 phosphate receptor (S1p1), a critical receptor controlling human lymphocyte trafficking, is expressed in hen and human ovaries and ovarian tumors. J Ovarian Res 4:4.

Bradbury A and Plückthun A (2015) Reproducibility: standardize antibodies used in research. Nature 518:27-29.

Bradshaw JM, McFarland JM, Paavilainen VO, Bisconte A, Tam D, Phan VT, Romanov S, Finkle D, Shu J, Patel V, et al. (2015) Prolonged and tunable residence time using reversible covalent kinase inhibitors. Nat Chem Biol 11:525-531.

Briard E, Orain D, Beerli C, Billich A, Streiff M, Bigaud M, and Auberson YP (2011) $\mathrm{BZM} 055$, an iodinated radiotracer candidate for PET and SPECT imaging of myelin and FTY720 brain distribution. ChemMedChem 6:667-677.

Briard E, Rudolph B, Desrayaud S, Krauser JA, and Auberson YP (2015) MS565: a SPECT tracer for evaluating the brain penetration of BAF312 (Siponimod). ChemMedChem 10:1008-1018.

Briscoe CP, Tadayyon M, Andrews JL, Benson WG, Chambers JK, Eilert MM, Ellis C, Elshourbagy NA, Goetz AS, Minnick DT, et al. (2003) The orphan G proteincoupled receptor GPR40 is activated by medium and long chain fatty acids. $J$ Biol Chem 278:11303-11311.

Brouwers AH, Laverman P, Boerman OC, Oyen WJ, Barrett JA, Harris TD, Edwards DS, and Corstens $\mathrm{FH}(2000) \mathrm{A}^{99} \mathrm{Tc}^{\mathrm{m}}$-labelled leukotriene $\mathrm{B}_{4}$ receptor antagonist for scintigraphic detection of infection in rabbits. Nucl Med Commun 21: 1043-1050.

Brown AJ, Goldsworthy SM, Barnes AA, Eilert MM, Tcheang L, Daniels D, Muir AI, Wigglesworth MJ, Kinghorn I, Fraser NJ, et al. (2003) The orphan G proteincoupled receptors GPR41 and GPR43 are activated by propionate and other short chain carboxylic acids. J Biol Chem 278:11312-11319.

Bruno A, Lembo F, Novellino E, Stornaiuolo M, and Marinelli L (2014) Beyond radiodisplacement techniques for identification of $\mathrm{CB}_{1}$ ligands: the first application of a fluorescence-quenching assay. Sci Rep 4:3757.

Burke L, Butler CT, Murphy A, Moran B, Gallagher WM, O'Sullivan J, and Kennedy $\mathrm{BN}$ (2016) Evaluation of cysteinyl leukotriene signaling as a therapeutic target for colorectal cancer. Front Cell Dev Biol 4:103.

Burns HD, Van Laere K, Sanabria-Bohórquez S, Hamill TG, Bormans G, Eng WS, Gibson R, Ryan C, Connolly B, Patel S, et al. (2007) $\left[{ }^{18} \mathrm{~F}\right] \mathrm{MK}-9470$, a positron emission tomography (PET) tracer for in vivo human PET brain imaging of the cannabinoid-1 receptor. Proc Natl Acad Sci USA 104:9800-9805.

Burstein SH, Audette CA, Charalambous A, Doyle SA, Guo Y, Hunter SA, and Makriyannis A (1991) Detection of cannabinoid receptors by photoaffinity labelling. Biochem Biophys Res Commun 176:492-497.

Bushlin I, Gupta A, Stockton Jr SD, Miller LK, and Devi LA (2012) Dimerization with cannabinoid receptors allosterically modulates delta opioid receptor activity during neuropathic pain. PLoS One 7:e49789.

Bussolati G and Leonardo E (2008) Technical pitfalls potentially affecting diagnoses in immunohistochemistry. J Clin Pathol 61:1184-1192.

Casteels C, Bormans G, and Van Laere K (2013) Brain Imaging of Cannabinoid Receptors, in Imaging of the Human Brain in Health and Disease (Seeman $P$ and Madras B eds) pp 37-79, Elsevier.

Castillo PE, Younts TJ, Chávez AE, and Hashimotodani Y (2012) Endocannabinoid signaling and synaptic function. Neuron 76:70-81.

Cavalla D and Neff NH (1985) Chemical mechanisms for photoaffinity labeling of receptors. Biochem Pharmacol 34:2821-2826.

Ceccarini J, Ahmad R, Van de Vliet L, Casteels C, Vandenbulcke M, Vandenberghe $\mathrm{W}$, and Van Laere K (2016a) CB1R PET in premanifest and manifest Huntington's disease is related to disease onset and disease burden. J Nucl Med 57:no. supplement 220 .

Ceccarini J, De Hert M, Van Winkel R, Peuskens J, Bormans G, Kranaster L, Enning F, Koethe D, Leweke FM, and Van Laere K (2013) Increased ventral striatal CB $_{1}$ receptor binding is related to negative symptoms in drug-free patients with schizophrenia. Neuroimage 79:304-312.

Ceccarini J, Hompes T, Verhaeghen A, Casteels C, Peuskens H, Bormans G, Claes S, and Van Laere $\mathrm{K}$ (2014) Changes in cerebral $\mathrm{CB}_{1}$ receptor availability after acute and chronic alcohol abuse and monitored abstinence. J Neurosci 34:2822-2831.

Ceccarini J, Kuepper R, Kemels D, van Os J, Henquet C, and Van Laere K (2015) $\left[{ }^{18} \mathrm{~F}\right] \mathrm{MK}-9470$ PET measurement of cannabinoid $\mathrm{CB}_{1}$ receptor availability in chronic cannabis users. Addict Biol 20:357-367.

Ceccarini J, Weltens N, Ly HG, Tack J, Van Oudenhove L, and Van Laere K (2016b) Association between cerebral cannabinoid 1 receptor availability and body mass index in patients with food intake disorders and healthy subjects: a $\left[\left({ }^{18)} \mathrm{F}\right] \mathrm{MK}-9470\right.$ PET study. Transl Psychiatry 6:e853.

Cécyre B, Thomas S, Ptito M, Casanova C, and Bouchard J-F (2014) Evaluation of the specificity of antibodies raised against cannabinoid receptor type 2 in the mouse retina. Naunyn Schmiedebergs Arch Pharmacol 387:175-184.

Chakravarty R, Goel S, and Cai W (2014) Nanobody: The "Magic Bullet" for Molecular Imaging? Theranostics 4:386-398.

Chao W and Olson MS (1993) Platelet-activating factor: receptors and signal transduction. Biochem J 292:617-629.

Chapman DI, Moss MS, Tomlinson PW, Harrison MP, and Simmons PJ (1980) The disposition and metabolism of the synthetic prostaglandin fluprostenol (ICI 81,008) in the horse. Xenobiotica 10:715-723.

Charalambous A, Yan G, Houston DB, Howlett AC, Compton DR, Martin BR, and Makriyannis A (1992) 5'-Azido-delta 8-THC: a novel photoaffinity label for the cannabinoid receptor. $J$ Med Chem 35:3076-3079.

Chau LY, Tsai YM, and Cheng JR (1989) Photoaffinity labeling of platelet activating factor binding sites in rabbit platelet membranes. Biochem Biophys Res Commun 161:1070-1076.

Chen Z, Dupré DJ, Le Gouill C, Rola-Pleszczynski M, and Stanková J (2002) Agonistinduced internalization of the platelet-activating factor receptor is dependent on arrestins but independent of G-protein activation: role of the $\mathrm{C}$ terminus and the (D/N)PXXY motif. J Biol Chem 277:7356-7362. 
Choe HW, Kim YJ, Park JH, Morizumi T, Pai EF, Krauss N, Hofmann KP, Scheerer P, and Ernst OP (2011) Crystal structure of metarhodopsin II. Nature 471:651-655.

Choi JW and Chun J (2013) Lysophospholipids and their receptors in the central nervous system. Biochim Biophys Acta 1831:20-32.

Choi JW, Herr DR, Noguchi K, Yung YC, Lee C-W, Mutoh T, Lin M-E, Teo ST, Park KE, Mosley AN, et al. (2010) LPA receptors: subtypes and biological actions. Annu Rev Pharmacol Toxicol 50:157-186.

Chrencik JE, Roth CB, Terakado M, Kurata H, Omi R, Kihara Y, Warshaviak D, Nakade S, Asmar-Rovira G, Mileni M, et al. (2015) Crystal structure of antagonist bound human lysophosphatidic acid receptor 1. Cell 161:1633-1643.

Christiansen E, Hudson BD, Hansen AH, Milligan G, and Ulven T (2016) Development and characterization of a potent free fatty acid receptor 1 (FFA1) fluorescent tracer. J Med Chem 59:4849-4858.

Christiansen E, Watterson KR, Stocker CJ, Sokol E, Jenkins L, Simon K, Grundmann M, Petersen RK, Wargent ET, Hudson BD, et al. (2015) Activity of dietary fatty acids on FFA1 and FFA4 and characterisation of pinolenic acid as a dual FFA1/FFA4 agonist with potential effect against metabolic diseases. Br J Nutr 113:1677-1688

Chu C, Ramamurthy A, Makriyannis A, and Tius MA (2003) Synthesis of covalent probes for the radiolabeling of the cannabinoid receptor. J Org Chem 68:55-61.

Chun J, Goetzl EJ, Hla T, Igarashi Y, Lynch KR, Moolenaar W, Pyne S, and Tigyi G (2002) International Union of Pharmacology. XXXIV. Lysophospholipid receptor nomenclature. Pharmacol Rev 54:265-269.

Chun J and Hartung H-P (2010) Mechanism of action of oral fingolimod (FTY720) in multiple sclerosis. Clin Neuropharmacol 33:91-101.

Chung SC, Hammarsten P, Josefsson A, Stattin P, Granfors T, Egevad L, Mancini G, Lutz B, Bergh A, and Fowler CJ (2009) A high cannabinoid $\mathrm{CB}\left({ }_{1}\right)$ receptor immunoreactivity is associated with disease severity and outcome in prostate cancer. Eur J Cancer 45:174-182.

Cipriani S, Mencarelli A, Bruno A, Renga B, Distrutti E, Santucci L, Baldelli F, and Fiorucci S (2013) Activation of the bile acid receptor GPBAR1 protects against gastrointestinal injury caused by non-steroidal anti-inflammatory drugs and aspirin in mice. $B r J$ Pharmacol 168:225-237.

Ciruela F, Jacobson KA, and Fernández-Dueñas V (2014) Portraying G proteincoupled receptors with fluorescent ligands. ACS Chem Biol 9:1918-1928.

Contos JJA, Ishii I, and Chun J (2000) Lysophosphatidic acid receptors. Mol Pharmacol 58:1188-1196.

Cooke RM, Brown AJH, Marshall FH, and Mason JS (2015) Structures of G proteincoupled receptors reveal new opportunities for drug discovery. Drug Discov Today 20:1355-1364.

Copple BL and Li T (2016) Pharmacology of bile acid receptors: evolution of bile acids from simple detergents to complex signaling molecules. Pharmacol Res 104:9-21.

Corminboeuf $\mathrm{O}$ and Leroy X (2015) FPR2/ALXR agonists and the resolution of inflammation. J Med Chem 58:537-559.

Cottet M, Faklaris O, Falco A, Trinquet E, Pin JP, Mouillac B, and Durroux T (2013) Fluorescent ligands to investigate GPCR binding properties and oligomerization. Biochem Soc Trans 41:148-153.

D'Souza DC, Cortes-Briones JA, Ranganathan M, Thurnauer H, Creatura G, Surti T, Planeta B, Neumeister A, Pittman B, Normandin MD, et al. (2016) Rapid changes in CB1 receptor availability in cannabis dependent males after abstinence from cannabis. Biol Psychiatry Cogn Neurosci Neuroimaging 1:60-67.

Dale CL, Hill SJ, and Kellam B (2012) New potent, short-linker BODIPY-630/650 ${ }^{\mathrm{TM}}$ labelled fluorescent adenosine receptor agonists. Med Chem Commun 3:333-338.

Daly C, Wallace G, White K, Chris H, Irving A, and McGrath J (2008) Visualisation of vascular cannabinoid receptors and their potential interaction with $\alpha_{1}$-adrenergic receptors, in Proceedings of The Physiological Society, The Physiological Society. King College London, Proc Physiol Soc 13, PC4, Dec 2008, p 55.

Daly CJ, Ross RA, Whyte J, Henstridge CM, Irving AJ, and McGrath JC (2010) Fluorescent ligand binding reveals heterogeneous distribution of adrenoceptors and 'cannabinoid-like' receptors in small arteries. Br J Pharmacol 159:787-796.

Davis TL and Sharif NA (1999) Quantitative autoradiographic visualization and pharmacology of FP-prostaglandin receptors in human eyes using the novel phosphor-imaging technology. J Ocul Pharmacol Ther 15:323-336.

Delgado A and Martínez-Cartro M (2016) Therapeutic potential of the modulation of sphingosine-1-phosphate receptors. Curr Med Chem 23:242-264.

Deutsch DG, Omeir R, Arreaza G, Salehani D, Prestwich GD, Huang Z, and Howlett A (1997) Methyl arachidonyl fluorophosphonate: a potent irreversible inhibitor of anandamide amidase. Biochem Pharmacol 53:255-260.

Devane WA, Dysarz 3rdFA, Johnson MR, Melvin LS, and Howlett AC (1988) Determination and characterization of a cannabinoid receptor in rat brain. $\mathrm{Mol}$ Pharmacol 34:605-613.

Devane WA, Hanus L, Breuer A, Pertwee RG, Stevenson LA, Griffin G, Gibson D, Mandelbaum A, Etinger A, and Mechoulam R (1992) Isolation and structure of a brain constituent that binds to the cannabinoid receptor. Science 258:1946-1949.

De Meyer T, Muyldermans S, and Depicker A (2014) Nanobody-based products as research and diagnostic tools. Trends in biotechnology 32:263-270.

Dhopeshwarkar A and Mackie $\mathrm{K}(2014) \mathrm{CB}_{2}$ cannabinoid receptors as a therapeutic target: what does the future hold? Mol Pharmacol 86:430-437.

Dixon DD, Tius MA, Thakur GA, Zhou H, Bowman AL, Shukla VG, Peng Y, and Makriyannis A (2012) C3-heteroaroyl cannabinoids as photolabeling ligands for the CB2 cannabinoid receptor. Bioorg Med Chem Lett 22:5322-5325.

Dogné JM, de Leval X, Benoit P, Rolin S, Pirotte B, and Masereel B (2002) Therapeutic potential of thromboxane inhibitors in asthma. Expert Opin Investig Drugs 11:275-281.

Dohlman HG, Caron MG, Strader CD, Amlaiky N, and Lefkowitz RJ (1988) Identification and sequence of a binding site peptide of the $\beta_{2}$-adrenergic receptor. Biochemistry 27:1813-1817.

Dowie MJ, Grimsey NL, Hoffman T, Faull RL, and Glass M (2014) Cannabinoid receptor $\mathrm{CB}_{2}$ is expressed on vascular cells, but not astroglial cells in the postmortem human Huntington's disease brain. J Chem Neuroanat 59-60:62-71.
Duboc H, Taché Y, and Hofmann AF (2014) The bile acid TGR5 membrane receptor: from basic research to clinical application. Dig Liver Dis 46:302-312.

Durand D, Hullot P, Vidal J-P, Girard J-P, Banères JL, Parello J, Muller A, Bonne C, and Rossi J-C (2000) Leukotriene $\mathrm{B}_{4}$ photoaffinity probes: design, synthesis and evaluation of new arylazide-1,3-disubstituted cyclohexanes. Bioorg Med Chem Lett 10:811-814.

Edwards LJ and Constantinescu CS (2009) Platelet activating factor/platelet activating factor receptor pathway as a potential therapeutic target in autoimmune diseases. Inflamm Allergy Drug Targets 8:182-190.

Emonds KM, Koole M, Casteels C, Van den Bergh L, Bormans GM, Claus F, De Wever L, Lerut E, Van Poppel H, Joniau S, et al. (2013) ${ }^{18}$ F-MK-9470 PET imaging of the type 1 cannabinoid receptor in prostate carcinoma: a pilot study. EJNMMI Res 3:59.

Engeli S, Böhnke J, Feldpausch M, Gorzelniak K, Janke J, Bátkai S, Pacher P, Harvey-White J, Luft FC, Sharma AM, et al. (2005) Activation of the peripheral endocannabinoid system in human obesity. Diabetes 54:2838-2843.

Evens N, Muccioli GG, Houbrechts N, Lambert DM, Verbruggen AM, Van Laere K, and Bormans GM (2009) Synthesis and biological evaluation of carbon-11- and fluorine-18-labeled 2-oxoquinoline derivatives for type 2 cannabinoid receptor positron emission tomography imaging. Nucl Med Biol 36:455-465.

Falk E, Müller M, Huber M, Keppler D, and Kurz G (1989) Direct photoaffinity labeling of leukotriene binding sites. Eur J Biochem 186:741-747.

Fan H, Ravert HT, Holt DP, Dannals RF, and Horti AG (2006) Synthesis of 1-(2,4-dichlorophenyl)-4-cyano-5-(4-[ $\left[{ }^{11} \mathrm{C}\right]$ methoxyphenyl)- $N$-(piperidin-1-yl)- $1 H$-pyrazole3-carboxamide ([ $\left.\left.{ }^{11} \mathrm{C}\right] J H U 75528\right)$ and 1-(2-bromophenyl)-4-cyano-5-(4- $\left[{ }^{11} \mathrm{C}\right]$ methoxyphenyl)$N$-piperidin-1-yl)- $1 H$-pyrazole-3-carboxamide $\left(\left[{ }^{11} \mathrm{C}\right] \mathrm{JHU} 75575\right)$ as potential radioligands for PET imaging of cerebral cannabinoid receptor. $J$ Labelled Comp Radiopharm 49:1021-1036.

Farez MF and Correale J (2016) Sphingosine 1-phosphate signaling in astrocytes: implications for progressive multiple sclerosis. J Neurol Sci 361:60-65.

Felder CC, Joyce KE, Briley EM, Mansouri J, Mackie K, Blond O, Lai Y, Ma AL and Mitchell RL (1995) Comparison of the pharmacology and signal transduction of the human cannabinoid $\mathrm{CB}_{1}$ and $\mathrm{CB}_{2}$ receptors. Mol Pharmacol 48:443-450.

Feldwisch J and Tolmachev V (2012) Engineering of affibody molecules for therapy and diagnostics. Methods Mol Biol. 899:103-126.

Fernando SR and Pertwee RG (1997) Evidence that methyl arachidonyl fluorophosphonate is an irreversible cannabinoid receptor antagonist. Br J Pharmacol 121:1716 1720

Ferreira SG, Gonçalves FQ, Marques JM, Tomé ÂR, Rodrigues RJ, Nunes-Correia I, Ledent C, Harkany T, Venance L, Cunha RA, et al. (2015) Presynaptic adenosine $\mathrm{A}_{2 \mathrm{~A}}$ receptors dampen cannabinoid $\mathrm{CB}_{1}$ receptor-mediated inhibition of corticostriatal glutamatergic transmission. Br J Pharmacol 172:1074-1086.

Feuerstein G, Rabinovici R, Leor J, Winkler JD, and Vonhof S (1997) Plateletactivating factor and cardiac diseases: therapeutic potential for PAF inhibitors. $J$ Lipid Mediat Cell Signal 15:255-284.

Fezza F, Oddi S, Di Tommaso M, De Simone C, Rapino C, Pasquariello N, Dainese E, Finazzi-Agrò A, and Maccarrone M (2008) Characterization of biotin-anandamide, a novel tool for the visualization of anandamide accumulation. J Lipid Res 49: $1216-1223$.

Fichna J, Bawa M, Thakur GA, Tichkule R, Makriyannis A, McCafferty D-M, Sharkey KA, and Storr M (2014) Cannabinoids alleviate experimentally induced intestinal inflammation by acting at central and peripheral receptors. PLoS One $\mathbf{9}$ e109115.

Flanagan ME, Abramite JA, Anderson DP, Aulabaugh A, Dahal UP, Gilbert AM, Li C, Montgomery J, Oppenheimer SR, Ryder T, et al. (2014) Chemical and computational methods for the characterization of covalent reactive groups for the prospective design of irreversible inhibitors. J Med Chem 57:10072-10079.

Flesch D, Merk D, Lamers C, and Schubert-Zsilavecz M (2013) Novel prostaglandin receptor modulators: part II: EP receptor modulators; a patent review (2002-2012). Expert Opin Ther Pat 23:233-267.

Forrest IS, Green DE, Rose SD, Skinner GC, and Torres DM (1971) Fluorescentlabeled cannabinoids. Res Commun Chem Pathol Pharmacol 2:787-792.

Fredriksson R and Schiöth HB (2005) The repertoire of G-protein-coupled receptors in fully sequenced genomes. Mol Pharmacol 67:1414-1425.

Fuchs H, Kishimoto W, Gansser D, Tanswell P, and Ishiguro N (2014) Brain penetration of WEB 2086 (Apafant) and dantrolene in Mdr1a (P-glycoprotein) and Bcrp knockout rats. Drug Metab Dispos 42:1761-1765

Fukushima N, Ishii S, Tsujiuchi T, Kagawa N, and Katoh K (2015) Comparative analyses of lysophosphatidic acid receptor-mediated signaling. Cell Mol Life Sci 72: $2377-2394$

Galiègue S, Mary S, Marchand J, Dussossoy D, Carrière D, Carayon P, Bouaboula M, Shire D, Le Fur G, and Casellas P (1995) Expression of central and periphera cannabinoid receptors in human immune tissues and leukocyte subpopulations. Eur J Biochem 232:54-61.

Gallant M, Sawyer N, Metters KM, and Zamboni RJ (1998) A novel photoaffinity probe for the $\mathrm{LTD}_{4}$ receptor. Bioorg Med Chem 6:63-72.

Ganesh T (2014) Prostanoid receptor EP2 as a therapeutic target. J Med Chem 57: $4454-4465$.

Gao M, Gao AC, Wang M, and Zheng Q-H (2014a) Synthesis of carbon-11-labeled aminoalkylindole derivatives as new candidates of cannabinoid receptor radioligands for PET imaging of alcohol abuse. Bioorg Med Chem Lett 24 5581-5586.

Gao M, Xu J, Wang M, and Zheng QH (2014b) Facile and high-yield synthesis of N-(4diethylamino)benzyl-4-[ $\left[{ }^{11} \mathrm{C}\right]$ methoxy- $\mathrm{N}$-(p-tolyl)benzenesulfonamide as a new potential PET selective CB2 radioligand. Appl Radiat Isot 90:181-186.

Gaoni Y and Mechoulam R (1964) Isolation, structure, and partial synthesis of an active constituent of hashish. J Am Chem Soc 86:1646-1647.

Gatley SJ, Lan R, Pyatt B, Gifford AN, Volkow ND, and Makriyannis A (1997) Binding of the non-classical cannabinoid CP 55,940, and the diarylpyrazole AM251 to rodent brain cannabinoid receptors. Life Sci 61:191-197. 
Ghasemi R, Dargahi L, and Ahmadiani A (2016) Integrated sphingosine-1 phosphate signaling in the central nervous system: from physiological equilibrium to pathological damage. Pharmacol Res 104:156-164.

Ghosh A, Chen F, Thakur A, and Hong H (2016) Cysteinyl leukotrienes and their receptors: emerging therapeutic targets in central nervous system disorders. CNS Neurosci Ther 22:943-951.

Ghosh E, Kumari P, Jaiman D, and Shukla AK (2015) Methodological advances: the unsung heroes of the GPCR structural revolution. Nat Rev Mol Cell Biol 16:69-81. Glass M, Dragunow M, and Faull RLM (1997) Cannabinoid receptors in the human brain: a detailed anatomical and quantitative autoradiographic study in the fetal, neonatal and adult human brain. Neuroscience 77:299-318.

Gobec M, Prijatelj M, Delić J, Markovič T, and Mlinarič-Raščan I (2014) Chemosensitizing effects of $\mathrm{EP}_{4}$ receptor-induced inactivation of nuclear factor-кB. Eur $J$ Pharmacol 742:81-88.

Golinski M, Heine M, Orlicky DJ, Fitz TA, and Watt DS (1992) Prostaglandin photoaffinity probes: synthesis and binding affinity of aryl azide-substituted C-1 esters of prostaglandin F2 alpha. Eicosanoids 5:99-107.

Gomes I, Gupta A, Bushlin I, and Devi LA (2014) Antibodies to probe endogenous G protein-coupled receptor heteromer expression, regulation, and function. Front Pharmacol 5:268.

Gonsiorek W, Hesk D, Chen SC, Kinsley D, Fine JS, Jackson JV, Bober LA, Deno G, Bian H, Fossetta J, et al. (2006) Characterization of peripheral human cannabinoid receptor (hCB2) expression and pharmacology using a novel radioligand, $\left[{ }^{35} \mathrm{~S}\right]$ Sch225336. J Biol Chem 281:28143-28151.

González-Núñez V, Bachert C, and Mullol J (2016) Rupatadine: global safety evaluation in allergic rhinitis and urticaria. Expert Opin Drug Saf 15:1439-1448.

Gräler MH, Bernhardt G, and Lipp M (1998) EDG6, a novel G-protein-coupled receptor related to receptors for bioactive lysophospholipids, is specifically expressed in lymphoid tissue. Genomics 53:164-169.

Grimsey NL, Goodfellow CE, Scotter EL, Dowie MJ, Glass M, and Graham ES (2008) Specific detection of $\mathrm{CB}_{1}$ receptors; cannabinoid $\mathrm{CB}_{1}$ receptor antibodies are not all created equal! J Neurosci Methods 171:78-86.

Guo Y, Abadji V, Morse KL, Fournier DJ, Li X, and Makriyannis A (1994) (-)-11Hydroxy-7'-isothiocyanato-1',1'-dimethylheptyl-delta 8-THC: a novel, high-affinity irreversible probe for the cannabinoid receptor in the brain. J Med Chem 37: 3867-3870.

Hakogi T, Shigenari T, Katsumura S, Sano T, Kohno T, and Igarashi Y (2003) Synthesis of fluorescence-labeled sphingosine and sphingosine 1-phosphate; effective tools for sphingosine and sphingosine 1-phosphate behavior. Bioorg Med Chem Let 13:661-664.

Hanasaki K, Nagasaki T, and Arita H (1989) Characterization of platelet thromboxane $\mathrm{A}_{2}$ /prostaglandin $\mathrm{H}_{2}$ receptor by a novel thromboxane receptor antagonist, $\left[{ }^{3} \mathrm{H}\right] \mathrm{S}-145$. Biochem Pharmacol 38:2007-2017.

Hanasaki K, Nakano K, Kasai H, Arita H, Ohtani K, and Doteuchi M (1988) Specific receptors for thromboxane $A_{2}$ in cultured vascular smooth muscle cells of rat aorta. Biochem Biophys Res Commun 150:1170-1175.

Hanson MA, Roth CB, Jo E, Griffith MT, Scott FL, Reinhart G, Desale H, Clemons B, Cahalan SM, Schuerer SC, et al. (2012) Crystal structure of a lipid G proteincoupled receptor. Science 335:851-855.

Hara T, Hirasawa A, Sun Q, Koshimizu TA, Itsubo C, Sadakane K, Awaji T, and Tsujimoto G (2009) Flow cytometry-based binding assay for GPR40 (FFAR1; free fatty acid receptor 1). Mol Pharmacol 75:85-91.

Hara T, Kashihara D, Ichimura A, Kimura I, Tsujimoto G, and Hirasawa A (2014) Role of free fatty acid receptors in the regulation of energy metabolism. Biochim Biophys Acta 1841:1292-1300.

Harris TD (2008) inventor. Preparation of paramagnetic nanoparticles conjugated to leukotriene b4 (ltb4) receptor antagonists, and their use as MRI contrast agents for the detection of infection and inflammation. U.S. patent 20080213181 A1. Bristol-Myers Squibb Pharma Compmany assignee, publication date 4 Sept 2008

Hecht JH, Weiner JA, Post SR, and Chun J (1996) Ventricular zone gene-1 (vzg-1) encodes a lysophosphatidic acid receptor expressed in neurogenic regions of the developing cerebral cortex. J Cell Biol 135:1071-1083.

Hedberg A, Hall SE, Ogletree ML, Harris DN, and Liu EC (1988) Characterization of $\left[5,6-{ }^{3} \mathrm{H}\right] \mathrm{SQ} 29,548$ as a high affinity radioligand, binding to thromboxane $\mathrm{A}_{2} /$ prostaglandin $\mathrm{H}_{2}$-receptors in human platelets. J Pharmacol Exp Ther 245:786-792.

Henstridge CM (2012) Off-target cannabinoid effects mediated by GPR55. Pharmacology 89:179-187.

Henstridge CM, Brown AJ, and Waldhoer M (2016) GPR55: metabolic help or hindrance? Trends Endocrinol Metab 27:606-608. 10.1016/j.tem.2016.1004.1012.

Herbert JM (1992) Characterization of specific binding sites of ${ }^{3} \mathrm{H}$-labelled plateletactivating factor $\left(\left[{ }^{3} \mathrm{H}\right] \mathrm{PAF}\right)$ and a new antagonist, $\left[{ }^{3} \mathrm{H}\right] \mathrm{SR} 27417$, on guinea-pig tracheal epithelial cells. Biochem $J$ 284:201-206.

Herkenham M, Lynn AB, Little MD, Johnson MR, Melvin LS, de Costa BR, and Rice KC (1990) Cannabinoid receptor localization in brain. Proc Natl Acad Sci USA 87: 1932-1936.

Hess C, Schoeder CT, Pillaiyar T, Madea B, and Müller CE (2016) Pharmacological evaluation of synthetic cannabinoids identified as constituents of spice. Forensic Toxicol 34:329-343.

Hillard CJ, Edgemond WS, Jarrahian A, and Campbell WB (1997) Accumulation of $\mathrm{N}$-arachidonoylethanolamine (anandamide) into cerebellar granule cells occurs via facilitated diffusion. $J$ Neurochem 69:631-638.

Hiller C, Kühhorn J, and Gmeiner P (2013) Class A G-protein-coupled receptor (GPCR) dimers and bivalent ligands. J Med Chem 56:6542-6559.

Hirai H, Tanaka K, Yoshie O, Ogawa K, Kenmotsu K, Takamori Y, Ichimasa M, Sugamura K, Nakamura M, Takano S, et al. (2001) Prostaglandin D2 selectively induces chemotaxis in T helper type 2 cells, eosinophils, and basophils via seventransmembrane receptor CRTH2. J Exp Med 193:255-261.

Hirasawa A, Tsumaya K, Awaji T, Katsuma S, Adachi T, Yamada M, Sugimoto Y, Miyazaki S, and Tsujimoto G (2005) Free fatty acids regulate gut incretin glucagon-like peptide-1 secretion through GPR120. Nat Med 11:90-94.
Hirata M, Hayashi Y, Ushikubi F, Yokota Y, Kageyama R, Nakanishi S, and Narumiya S (1991) Cloning and expression of cDNA for a human thromboxane $\mathrm{A}_{2}$ receptor. Nature 349:617-620.

Hla T and Maciag T (1990) An abundant transcript induced in differentiating human endothelial cells encodes a polypeptide with structural similarities to G-proteincoupled receptors. J Biol Chem 265:9308-9313.

Honda Z, Nakamura M, Miki I, Minami M, Watanabe T, Seyama Y, Okado H, Toh H Ito K, Miyamoto T, et al. (1991) Cloning by functional expression of plateletactivating factor receptor from guinea-pig lung. Nature 349:342-346.

Honda Z, Takano T, Gotoh Y, Nishida E, Ito K, and Shimizu T (1994) Transfected platelet-activating factor receptor activates mitogen-activated protein (MAP) kinase and MAP kinase kinase in Chinese hamster ovary cells. J Biol Chem 269: 2307-2315.

Hong G, Antaris AL, and Dai H (2017) Near-infrared fluorophores for biomedical imaging. Nature Biomedical Engineering 1:1-22.

Hortala L, Arnaud J, Roux P, Oustric D, Boulu L, Oury-Donat F, Avenet P, Rooney T, Alagille D, Barret O, et al. (2014) Synthesis and preliminary evaluation of a new fluorine-18 labelled triazine derivative for PET imaging of cannabinoid CB2 receptor. Bioorg Med Chem Lett 24:283-287.

Horti AG, Raymont V, and Terry GE (2014) PET Imaging of Endocannabinoid System, in PET and SPECT of Neurobiological Systems (Dierckx RAJO, Otte A, de Vries EFJ, van Waarde A, and Luiten PGM eds) pp 249-319, Springer-Verlag, Berlin Heidelberg.

Howlett AC, Wilken GH, Pigg JJ, Houston DB, Lan R, Liu Q, and Makriyannis A (2000) Azido- and isothiocyanato-substituted aryl pyrazoles bind covalently to the $\mathrm{CB}_{1}$ cannabinoid receptor and impair signal transduction. $J$ Neurochem $\mathbf{7 4}$ 2174-2181.

Hua T, Vemuri K, Pu M, Qu L, Han GW, Wu Y, Zhao S, Shui W, Li S, Korde A, et al. (2016) Crystal structure of the human cannabinoid receptor CB1. Cell 167: 750-762.e14

Hudson BD, Murdoch H, and Milligan G (2013) Minireview: the effects of species ortholog and SNP variation on receptors for free fatty acids. Mol Endocrinol 27: $1177-1187$

Hudson BD, Smith NJ, and Milligan G (2011) Experimental challenges to targeting poorly characterized GPCRs: uncovering the therapeutic potential for free fatty acid receptors. Adv Pharmacol 62:175-218.

Hurst DP, Grossfield A, Lynch DL, Feller S, Romo TD, Gawrisch K, Pitman MC and Reggio PH (2010) A lipid pathway for ligand binding is necessary for a cannabinoid G protein-coupled receptor. J Biol Chem 285:17954-17964.

Hurst DP, Schmeisser M, and Reggio PH (2013) Endogenous lipid activated G protein-coupled receptors: emerging structural features from crystallography and molecular dynamics simulations. Chem Phys Lipids 169:46-56.

Hutchings CJ, Koglin M, and Marshall FH (2010) Therapeutic antibodies directed at G protein-coupled receptors. MAbs 2:594-606.

Hwang SB, Lam MH, and Chang MN (1986) Specific binding of $\left[{ }^{3} \mathrm{H}\right]$ dihydrokadsurenone to rabbit platelet membranes and its inhibition by the receptor agonists and antagonists of platelet-activating factor. J Biol Chem 261: 13720-13726.

Hwang SB, Lam MH, and Hsu AH (1989) Characterization of platelet-activating factor (PAF) receptor by specific binding of $\left[{ }^{3} \mathrm{H}\right] \mathrm{L}-659,989$, a PAF receptor antagonist, to rabbit platelet membranes: possible multiple conformational states of a single type of PAF receptors. Mol Pharmacol 35:48-58.

Ito S, Hashimoto H, Negishi M, Suzuki M, Koyano H, Noyori R, and Ichikawa A (1992) Identification of the prostacyclin receptor by use of $\left[15^{3} \mathrm{H}_{1}\right] 19-(3$ azidophenyl)-20-norisocarbacyclin, an irreversible specific photoaffinity probe. $J$ Biol Chem 267:20326-20330.

Itoh Y, Kawamata Y, Harada M, Kobayashi M, Fujii R, Fukusumi S, Ogi K, Hosoya M, Tanaka Y, Uejima H, et al. (2003) Free fatty acids regulate insulin secretion from pancreatic $\beta$ cells through GPR40. Nature 422:173-176.

Ivell R, Teerds K, and Hoffman GE (2014) Proper application of antibodies for immunohistochemical detection: antibody crimes and how to prevent them. Endocrinology 155:676-687.

Jackson RH, Morrissey MM, Sills MA, and Jarvis MF (1992) Comparison of antagonist and agonist binding to the leukotriene $\mathrm{B}_{4}$ receptor intact human polymorphonuclear neutrophils (PMN). J Pharmacol Exp Ther 262:80-89.

Jacobson KA (2015) New paradigms in GPCR drug discovery. Biochem Pharmacol 98: $541-555$

Janero DR, Yaddanapudi S, Zvonok N, Subramanian KV, Shukla VG, Stahl E, Zhou L, Hurst D, Wager-Miller J, Bohn LM, et al. (2015) Molecular-interaction and signaling profiles of AM3677, a novel covalent agonist selective for the cannabinoid 1 receptor. ACS Chem Neurosci 6:1400-1410.

Jansen EM, Haycock DA, Ward SJ, and Seybold VS (1992) Distribution of cannabinoid receptors in rat brain determined with aminoalkylindoles. Brain Res 575: 93-102.

Jean-Gilles L, Braitch M, Latif ML, Aram J, Fahey AJ, Edwards LJ, Robins RA, Tanasescu R, Tighe PJ, Gran B, et al. (2015) Effects of pro-inflammatory cytokines on cannabinoid $\mathrm{CB}_{1}$ and $\mathrm{CB}_{2}$ receptors in immune cells. Acta Physiol (Oxf) 214 63-74.

Jia N, Zhang S, Shao P, Bagia C, Janjic JM, Ding Y, and Bai M (2014) Cannabinoid CB2 receptor as a new phototherapy target for the inhibition of tumor growth. Mol Pharm 11:1919-1929.

Jin H, Yang H, Liu H, Zhang Y, Zhang X, Rosenberg AJ, Liu Y, Lapi SE, and Tu Z (2017) A promising carbon-11-labeled sphingosine-1-phosphate receptor 1-specific PET tracer for imaging vascular injury. J Nucl Cardiol 24:558-570.

Jo E, Bhhatarai B, Repetto E, Guerrero M, Riley S, Brown SJ, Kohno Y, Roberts E, Schürer SC, and Rosen H (2012) Novel selective allosteric and bitopic ligands for the $\mathrm{S}_{1 \mathrm{P}}\left({ }_{3}\right)$ receptor. ACS Chem Biol 7:1975-1983.

Johnson DS, Weerapana E, and Cravatt BF (2010) Strategies for discovering and derisking covalent, irreversible enzyme inhibitors. Future Med Chem 2: 949-964. 
Just WW, Werner G, and Wiechmann M (1972) Bestimmung von delta 1- und delta 1 (6)-tetrahydrocannabinol in Blut, Urin und Speichel von Haschisch-Rauchern. Naturwissenschaften 59:222.

Kaku K, Enya K, Nakaya R, Ohira T, and Matsuno R (2015) Efficacy and safety of fasiglifam (TAK-875), a G protein-coupled receptor 40 agonist, in Japanese patients with type 2 diabetes inadequately controlled by diet and exercise: a randomized, double-blind, placebo-controlled, phase III trial. Diabetes Obes Metab 17: $675-681$.

Kano M, Ohno-Shosaku T, Hashimotodani Y, Uchigashima M, and Watanabe M (2009) Endocannabinoid-mediated control of synaptic transmission. Physiol Rev 89:309-380.

Kasperska-Zajac A, Brzoza Z, and Rogala B (2008) Platelet-activating factor (PAF): a review of its role in asthma and clinical efficacy of PAF antagonists in the disease therapy. Recent Pat Inflamm Allergy Drug Discov 2:72-76.

Kataoka M, Ishibashi K, Kumagai S, Yanagida T, Aikawa K, Chiba H, and Kojima Y (2015) Expression and function of LPA1 in bladder cancer. J Urol 194:238-244.

Katona I and Freund TF (2012) Multiple functions of endocannabinoid signaling in the brain, in Annual Review of Neuroscience (Hyman SE ed) vol 35, pp 529-558. Annual Reviews, CA, USA.

Katritch V, Cherezov V, and Stevens RC (2012) Diversity and modularity of G protein-coupled receptor structures. Trends Pharmacol Sci 33:17-27.

Katsuyama M, Sugimoto Y, Namba T, Irie A, Negishi M, Narumiya S, and Ichikawa A (1994) Cloning and expression of a cDNA for the human prostacyclin receptor. FEBS Lett 344:74-78.

Kattelman EJ, Arora SK, Lim CT, Venton DL, and Le Breton GC (1987) A photoaffinity label for the thromboxane $\mathrm{A}_{2}$ /prostaglandin $\mathrm{H}_{2}$ receptor in human blood platelets. FEBS Lett 213:179-183.

Kattelman EJ, Venton DL, and Le Breton GC (1986) Characterization of U46619 binding in unactivated, intact human platelets and determination of binding site affinities of four $\mathrm{TXA}_{2} / \mathrm{PGH}_{2}$ receptor antagonists (13-APA, BM 13.177, ONO 3708 and SQ 29,548). Thromb Res 41:471-481.

Kawada K, Pralong E, Vesin MF, Fitz TA, and Watt DS (1991) Prostaglandin photoaffinity probes: synthesis and binding affinity of an azide-substituted 17-phenyl $\mathrm{PGE}_{2}$ prostaglandin. Eicosanoids 4:57-60.

Keam SJ, Lyseng-Williamson KA, and Goa KL (2003) Pranlukast: a review of its use in the management of asthma. Drugs 63:991-1019.

Kearn CS, Greenberg MJ, DiCamelli R, Kurzawa K, and Hillard CJ (1999) Relationships between ligand affinities for the cerebellar cannabinoid receptor CB1 and the induction of GDP/GTP exchange. J Neurochem 72:2379-2387.

Keenan CM, Storr MA, Thakur GA, Wood JT, Wager-Miller J, Straiker A, Eno MR, Nikas SP, Bashashati M, Hu H, et al. (2015) AM841, a covalent cannabinoid ligand, powerfully slows gastrointestinal motility in normal and stressed mice in a peripherally restricted manner. Br J Pharmacol 172:2406-2418.

Kelesidis T, Papakonstantinou V, Detopoulou P, Fragopoulou E, Chini M, Lazanas MC, and Antonopoulou S (2015) The role of platelet-activating factor in chronic inflammation, immune activation, and comorbidities associated with HIV infection. AIDS Rev 17:191-201.

Kelloway JS (1997) Zafirlukast: the first leukotriene-receptor antagonist approved for the treatment of asthma. Ann Pharmacother 31:1012-1021.

Kennedy AP, Mangum KC, Linden J, and Wells JN (1996) Covalent modification of transmembrane span III of the $\mathrm{A}_{1}$ adenosine receptor with an antagonist photoaffinity probe. Mol Pharmacol 50:789-798.

Khan MZ and He L (2017) The role of polyunsaturated fatty acids and GPR40 receptor in brain. Neuropharmacology 113:639-651. 10.1016/j.neuropharm.2015.1005.1013.

Khanolkar AD, Palmer SL, and Makriyannis A (2000) Molecular probes for the cannabinoid receptors. Chem Phys Lipids 108:37-52.

Kihara Y, Mizuno H, and Chun J (2015) Lysophospholipid receptors in drug discovery. Exp Cell Res 333:171-177.

Kiriyama M, Ushikubi F, Kobayashi T, Hirata M, Sugimoto Y, and Narumiya S (1997) Ligand binding specificities of the eight types and subtypes of the mouse prostanoid receptors expressed in Chinese hamster ovary cells. $\mathrm{Br} J$ Pharmacol 122:217-224

Klotz P, Foucaud B, Goeldner MP, and Hirth CG (1993) Total synthesis of photoactivatable peptidoleukotriene analogs. The description of $7(Z), 9(E)$ - and $7(E), 9(E)$ leukotriene $\mathrm{D}_{2}$ aryldiazonium derivatives as potential photoaffinity probes for the leukotriene $\mathrm{C}_{4}$ receptor. $J$ Org Chem 58:1076-1082

Knebel SM, Sprague RS, and Stephenson AH (2015) Prostacyclin receptor expression on platelets of humans with type 2 diabetes is inversely correlated with hemoglobin A1c levels. Prostaglandins Other Lipid Mediat 116-117: 131-135

Kobilka BK and Deupi X (2007) Conformational complexity of G-protein-coupled receptors. Trends Pharmacol Sci 28:397-406.

Koga D, Santa T, Hagiwara K, Imai K, Takizawa H, Nagano T, Hirobe M, Ogawa M, Sato T, Inoue K, et al. (1995) High-performance liquid chromatography and fluorometric detection of arachidonylethanolamide (anandamide) and its analogues, derivatized with 4-( $N$-chloroformylmethyl- $N$-methyl)amino-7- $N, N$ dimethylaminosulp honyl-2,1, 3-benzoxadiazole (DBD-COCl). Biomed Chromatogr 9:56-57.

Koltai M and Braquet PG (1994) Platelet-activating factor antagonists. Clin Rev Allergy 12:361-380.

Konya V, Marsche G, Schuligoi R, and Heinemann A (2013) E-type prostanoid receptor 4 (EP4) in disease and therapy. Pharmacol Ther 138:485-502.

Korbecki J, Baranowska-Bosiacka I, Gutowska I, and Chlubek D (2014) Cyclooxygenase pathways. Acta Biochim Pol 61:639-649.

Kotarsky K, Nilsson NE, Flodgren E, Owman C, and Olde B (2003) A human cell surface receptor activated by free fatty acids and thiazolidinedione drugs. Biochem Biophys Res Commun 301:406-410.

Krishnan S, Miller RM, Tian B, Mullins RD, Jacobson MP, and Taunton J (2014) Design of reversible, cysteine-targeted Michael acceptors guided by kinetic and computational analysis. J Am Chem Soc 136:12624-12630.
Kulkarni PM, Kulkarni AR, Korde A, Tichkule RB, Laprairie RB, Denovan-Wright EM, Zhou H, Janero DR, Zvonok N, Makriyannis A, et al. (2016) Novel electrophilic and photoaffinity covalent probes for mapping the cannabinoid 1 receptor allosteric site(s). J Med Chem 59:44-60.

Kung HF, Kung MP, and Choi SR (2003) Radiopharmaceuticals for single-photon emission computed tomography brain imaging. Semin Nucl Med 33:2-13.

Kusano K, Tanaka S, Ando T, Abe Y, Ida S, and Yuzuriha T (1993) Metabolic polymorphism of E6123 in rhesus monkey. Xenobiotica 23:599-608.

Lamers C, Flesch D, Schubert-Zsilavecz M, and Merk D (2013) Novel prostaglandin receptor modulators: a patent review (2002-2012): part I: non-EP receptor modulators. Expert Opin Ther Pat 23:47-77.

Laprairie RB, Kulkarni AR, Kulkarni PM, Hurst DP, Lynch D, Reggio PH, Janero DR, Pertwee RG, Stevenson LA, and Kelly ME, et al. (2016) Mapping cannabinoid 1 receptor allosteric site(s): critical molecular determinant and signaling profile of GAT100, a novel, potent, and irreversibly binding probe. ACS Chem Neurosci 7: $776-798$.

Le Poul E, Loison C, Struyf S, Springael JY, Lannoy V, Decobecq ME, Brezillon S, Dupriez V, Vassart G, Van Damme J, et al. (2003) Functional characterization of human receptors for short chain fatty acids and their role in polymorphonuclear cell activation. $J$ Biol Chem 278:25481-25489.

Leusch A, Volz A, Müller G, Wagner A, Sauer A, Greischel A, and Roth W (2002) Altered drug disposition of the platelet activating factor antagonist apafant in mdr1a knockout mice. Eur J Pharm Sci 16:119-128.

Li C, Xu W, Vadivel SK, Fan P, and Makriyannis A (2005) High affinity electrophilic and photoactivatable covalent endocannabinoid probes for the CB1 receptor. J Med Chem 48:6423-6429.

Lieu T, Jayaweera G, and Bunnett NW (2014) GPBA: a GPCR for bile acids and an emerging therapeutic target for disorders of digestion and sensation. $\mathrm{Br} J \mathrm{Phar}$ macol 171:1156-1166.

Lin DCH, Guo Q, Luo J, Zhang J, Nguyen K, Chen M, Tran T, Dransfield PJ, Brown SP, Houze J, et al. (2012) Identification and pharmacological characterization of multiple allosteric binding sites on the free fatty acid 1 receptor. Mol Pharmacol 82:843-859.

Ling X, Zhang S, Shao P, Li W, Yang L, Ding Y, Xu C, Stella N, and Bai M (2015) A novel near-infrared fluorescence imaging probe that preferentially binds to cannabinoid receptors $\mathrm{CB}_{2} \mathrm{R}$ over $\mathrm{CB}_{1} \mathrm{R}$. Biomaterials 57:169-178.

Lipman NS, Jackson LR, Trudel LJ, and Weis-Garcia F (2005) Monoclonal versus polyclonal antibodies: distinguishing characteristics, applications, and information resources. ILAR J 46:258-268.

Liu M and Yokomizo T (2015) The role of leukotrienes in allergic diseases. Allergol Int 64:17-26.

Liu S, Harris AR, Williams NE, and Edwards DS (2002) ${ }^{99 m}$ Tc-Labeling of a hydrazinonicotinamide-conjugated $\mathrm{LTB}_{4}$ ) receptor antagonist useful for imaging infection and inflammation. Bioconjug Chem 13:881-886.

Llona-Minguez S, Ghassemian A, and Helleday T (2015) Lysophosphatidic acid receptor (LPAR) modulators: the current pharmacological toolbox. Prog Lipid Res 58: $51-75$

Lorincz A and Nusser Z (2008) Specificity of immunoreactions: the importance of testing specificity in each method. $J$ Neurosci 28:9083-9086.

Lucas CM, Harris RJ, Giannoudis A, McDonald E, and Clark RE (2014) Low leukotriene B4 receptor 1 leads to ALOX5 downregulation at diagnosis of chronic myeloid leukemia. Haematologica 99:1710-1715.

Lukashova V, Asselin C, Krolewski JJ, Rola-Pleszczynski M, and Stanková J (2001) G-protein-independent activation of Tyk2 by the platelet-activating factor receptor. $J$ Biol Chem 276:24113-24121.

Luu VT, Goujon J-Y, Meisterhans C, Frommherz M, and Bauer C (2015) Synthesis of a high specific activity methyl sulfone tritium isotopologue of fevipiprant (NVPQAW039). J Labelled Comp Radiopharm 58:188-195.

Ly HG, Ceccarini J, Weltens N, Bormans G, Van Laere K, Tack J, and Van Oudenhove L (2015) Increased cerebral cannabinoid-1 receptor availability is a stable feature of functional dyspepsia: a [F]MK-9470 PET study. Psychother Psychosom 84 $149-158$

Ma Z, Du L, and Li M (2014) Toward fluorescent probes for G-protein-coupled receptors (GPCRs). J Med Chem 57:8187-8203.

Machado FC, Zambelli VO, Fernandes ACO, Heimann AS, Cury Y, and Picolo G (2014) Peripheral interactions between cannabinoid and opioid systems contribute to the antinociceptive effect of crotalphine. Br J Pharmacol 171:961-972.

Maeda Y, Yagi H, Takemoto K, Utsumi H, Fukunari A, Sugahara K, Masuko T, and Chiba K (2014) S1P lyase in thymic perivascular spaces promotes egress of mature thymocytes via up-regulation of $\mathrm{S} 1 \mathrm{P}$ receptor 1 . Int Immunol $\mathbf{2 6}$ $245-255$

Mais DE, Bowling NL, True TA, Naka M, Morinelli TA, Oatis Jr JE, Hamanaka N, and Halushka PV (1991) Novel synthesis and biochemical properties of an $\left[{ }^{125} \mathrm{I}\right]$ labeled photoaffinity probe for thromboxane $\mathrm{A}_{2} /$ prostaglandin $\mathrm{H}_{2}$ receptors. $\mathrm{J} \mathrm{Med}$ Chem 34:1511-1514.

Mais DE, Burch RM, Oatis Jr JE, Knapp DR, and Halushka PV (1986) Photoaffinity labelling of a thromboxane $\mathrm{A}_{2}$ /prostaglandin $\mathrm{H}_{2}$ antagonist binding site in human platelets. Biochem Biophys Res Commun 140:128-133.

Mais DE and Halushka PV (1989) Photoaffinity labelling and isoelectric focusing of the human platelet thromboxane $\mathrm{A}_{2} /$ prostaglandin $\mathrm{H}_{2}\left(\mathrm{TXA}_{2} / \mathrm{PGH}_{2}\right)$ receptor. $\mathrm{Adv}$ Prostaglandin Thromboxane Leukot Res 19:168-171.

Mais DE, Liel N, and Halushka PV (1990) Photoaffinity receptor antagonist for human platelet thromboxane $\mathrm{A}_{2}$ /prostaglandin $\mathrm{H}_{2}$ receptors. Biochem Pharmacol 40: $1457-1461$

Mais DE, True TA, and Martinelli MJ (1992) Characterization by photoaffinity labelling of the human platelet thromboxane $\mathrm{A}_{2} /$ prostaglandin $\mathrm{H}_{2}$ receptor: evidence for N-linked glycosylation. Eur J Pharmacol 227:267-274.

Mais DE, Yoakim C, Guindon Y, Gillard JW, Rokach J, and Halushka PV (1989) Photoaffinity labelling of the human platelet thromboxane $\mathrm{A}_{2} /$ prostaglandin $\mathrm{H}_{2}$ receptor. Biochim Biophys Acta 1012:184-190. 
Májer F, Salomon JJ, Sharma R, Etzbach SV, Najib MNM, Keaveny R, Long A, Wang J, Ehrhardt C, and Gilmer JF (2012) New fluorescent bile acids: synthesis, chemical characterization, and disastereoselective uptake by Caco-2 cells of 3-deoxy 3-NBD-amino deoxycholic and ursodeoxycholic acid. Bioorg Med Chem 20: 1767-1778.

Makriyannis A (2014) 2012 Division of medicinal chemistry award address: trekking the cannabinoid road: a personal perspective. J Med Chem 57:3891-3911.

Makriyannis A and Rapaka RS (1990) The molecular basis of cannabinoid activity. Life Sci 47:2173-2184.

Mancini AD and Poitout V (2013) The fatty acid receptor FFA1/GPR40 a decade later: how much do we know? Trends Endocrinol Metab 24:398-407.

Manera C, Saccomanni G, Adinolfi B, Benetti V, Ligresti A, Cascio MG, Tuccinardi T, Lucchesi V, Martinelli A, Nieri P, et al. (2009) Rational design, synthesis, and pharmacological properties of new 1,8-naphthyridin-2(1H)-on-3-carboxamide derivatives as highly selective cannabinoid-2 receptor agonists. $J$ Med Chem 52: 3644-3651.

Marathe GK, Pandit C, Lakshmikanth CL, Chaithra VH, Jacob SP, and D'Souza CJ (2014) To hydrolyze or not to hydrolyze: the dilemma of platelet-activating factor acetylhydrolase. J Lipid Res 55:1847-1854.

Marchalant Y, Brownjohn PW, Bonnet A, Kleffmann T, and Ashton JC (2014) Validating antibodies to the cannabinoid CB2 receptor: antibody sensitivity is not evidence of antibody specificity. J Histochem Cytochem 62:395-404.

Marcu J, Shore DM, Kapur A, Trznadel M, Makriyannis A, Reggio PH, and Abood $\mathrm{ME}$ (2013) Novel insights into $\mathrm{CB}_{1}$ cannabinoid receptor signaling: a key interaction identified between the extracellular-3 loop and transmembrane helix $2 . J$ Pharmacol Exp Ther 345:189-197.

Markovič T, Jakopin Ž, Dolenc MS, and Mlinarič-Raščan I (2017) Structural features of subtype-selective EP receptor modulators. Drug Discov Today 22: $57-71$

Marquis O, Robaut C, and Cavero I (1988) [ $\left.{ }^{3} \mathrm{H}\right] 52770 \mathrm{RP}$, a platelet-activating factor receptor antagonist, and tritiated platelet-activating factor label a common specific binding site in human polymorphonuclear leukocytes. J Pharmacol Exp Ther 244: $709-715$

Martín-Couce L, Martín-Fontecha M, Capolicchio S, López-Rodríguez ML, and Ortega-Gutiérrez S (2011) Development of endocannabinoid-based chemical probes for the study of cannabinoid receptors. J Med Chem 54:5265-5269.

Martín-Couce L, Martín-Fontecha M, Palomares Ó Mestre L, Cordomí A, Hernangomez M, Palma S, Pardo L, Guaza C, López-Rodríguez ML, and Ortega-Gutiérrez S (2012) Chemical Probes for the Recognition of Cannabinoid Receptors in Native Systems. Angew Chem Int Ed 51:6896-6899.

Martín-Fontecha M, Eiwegger T, Jartti T, Rueda-Zubiaurre A, Tiringer K, Stepanow J, Puhakka T, Rückert B, Ortega-Gutiérrez S, López-Rodríguez ML, et al. (2014 The expression of cannabinoid receptor 1 is significantly increased in atopic patients. J Allergy Clin Immunol 133:926-929.e2.

Maruyama T, Miyamoto Y, Nakamura T, Tamai Y, Okada H, Sugiyama E, Nakamura T, Itadani H, and Tanaka K (2002) Identification of membrane-type receptor for bile acids (M-BAR). Biochem Biophys Res Commun 298:714-719.

Matsuda LA, Lolait SJ, Brownstein MJ, Young AC, and Bonner TI (1990) Structure of a cannabinoid receptor and functional expression of the cloned cDNA. Nature 346:561-564

Matsui H, Lefkowitz RJ, Caron MG, and Regan JW (1989) Localization of the fourth membrane spanning domain as a ligand binding site in the human platelet $\alpha_{2^{-}}$ adrenergic receptor. Biochemistry 28:4125-4130.

Matsuo T and Cynader MS (1992) Localisation of prostaglandin F2 $\alpha$ and E2 binding sites in the human eye. $\mathrm{Br}$ J Ophthalmol 76:210-213.

Matsuo T and Cynader MS (1993) The EP2 receptor is the predominant prostanoid receptor in the human ciliary muscle. $\mathrm{Br} J$ Ophthalmol 77:110-114.

Mauler F, Horváth E, De Vry J, Jäger R, Schwarz T, Sandmann S, Weinz C, Heinig R, and Böttcher M (2003) BAY 38-7271: a novel highly selective and highly potent cannabinoid receptor agonist for the treatment of traumatic brain injury. CNS Drug Rev 9:343-358.

May LT, Briddon SJ, and Hill SJ (2010) Antagonist selective modulation of adenosine $\mathrm{A}_{1}$ and $\mathrm{A}_{3}$ receptor pharmacology by the food dye Brilliant Black BN: evidence for allosteric interactions. Mol Pharmacol 77:678-686.

Mechoulam R, Ben-Shabat S, Hanus L, Ligumsky M, Kaminski NE, Schatz AR, Gopher A, Almog S, Martin BR, Compton DR, et al. (1995) Identification of an endogenous 2-monoglyceride, present in canine gut, that binds to cannabinoid receptors. Biochem Pharmacol 50:83-90.

Meng X-D, Wei D, Li J, Kang J-J, Wu C, Ma L, Yang F, Zhu G-M, Ou-Yang T-P, Liu Y-Y, et al. (2014) Astrocytic expression of cannabinoid type 1 receptor in rat and human sclerotic hippocampi. Int J Clin Exp Pathol 7:2825-2837.

Mercier RW, Pei Y, Pandarinathan L, Janero DR, Zhang J, and Makriyannis A (2010) hCB2 ligand-interaction landscape: cysteine residues critical to biarylpyrazole antagonist binding motif and receptor modulation. Chem Biol 17:1132-1142.

Metters KM and Zamboni RJ (1993) Photoaffinity labeling of the leukotriene $\mathrm{D}_{4}$ receptor in guinea pig lung. $J$ Biol Chem 268:6487-6495.

Michalak M, Wandler EL, Strynadka K, Lopaschuk GL, Njue WM, Liu HJ, and Olley PM (1990) Photolabelling of the prostaglandin $\mathrm{E}_{2}$ receptor in cardiac sarcolemmal vesicles. FEBS Lett 265:117-120.

Middle S, Coupland SE, Taktak A, Kidgell V, Slupsky JR, Pettitt AR, and Till KJ (2015) Immunohistochemical analysis indicates that the anatomical location of B-cell non-Hodgkin's lymphoma is determined by differentially expressed chemokine receptors, sphingosine-1-phosphate receptors and integrins. Exp Hematol Oncol 4:10.

Miller PW, Long NJ, Vilar R, and Gee AD (2008) Synthesis of ${ }^{11} \mathrm{C},{ }^{18} \mathrm{~F},{ }^{15} \mathrm{O}$, and ${ }^{13} \mathrm{~N}$ radiolabels for positron emission tomography. Angew Chem Int Ed Engl 47: 8998-9033.

Milligan G, Alvarez-Curto E, Watterson KR, Ulven T, and Hudson BD (2015) Characterizing pharmacological ligands to study the long-chain fatty acid receptors GPR40/FFA1 and GPR120/FFA4. Br J Pharmacol 172:3254-3265.
Milligan G, Shimpukade B, Ulven T, and Hudson BD (2017) Complex pharmacology of free fatty acid receptors. Chem Rev 117:67-110. 10.1021/acs.chemrev.1026b00056.

Milligan G, Ulven T, Murdoch H, and Hudson BD (2014) G-protein-coupled receptors for free fatty acids: nutritional and therapeutic targets. Br J Nutr 111 (Suppl 1): S3-S7

Miras CJ (1965) Some aspects of cannabis action, in Hashish, Its chemistry and pharmacology, Ciba Foundation Study Group No 21 (Wolstenholme GEW and Knight J eds) J. \& A. Churchill, London.

Mizuta K, Zhang Y, Mizuta F, Hoshijima H, Shiga T, Masaki E, and Emala SrCW (2015) Novel identification of the free fatty acid receptor FFAR1 that promotes contraction in airway smooth muscle. Am J Physiol Lung Cell Mol Physiol 309: L970-L982.

Morinelli TA, Oatis Jr JE, Okwu AK, Mais DE, Mayeux PR, Masuda A, Knapp DR, and Halushka PV (1989) Characterization of an 125I-labeled thromboxane $\mathrm{A}_{2} /$ prostaglandin $\mathrm{H}_{2}$ receptor agonist. $J$ Pharmacol Exp Ther 251:557-562.

Morozov YM, Dominguez MH, Varela L, Shanabrough M, Koch M, Horvath TL, and Rakic P (2013) Antibodies to cannabinoid type 1 receptor co-react with stomatin-like protein 2 in mouse brain mitochondria. Eur $J$ Neurosci 38: 2341-2348.

Morse KL, Fournier DJ, Li X, Grzybowska J, and Makriyannis A (1995) A novel electrophilic high affinity irreversible probe for the cannabinoid receptor. Life Sci 56:1957-1962.

Moser N, Mechawar N, Jones I, Gochberg-Sarver A, Orr-Urtreger A, Plomann M, Salas R, Molles B, Marubio L, Roth U, et al. (2007) Evaluating the suitability of nicotinic acetylcholine receptor antibodies for standard immunodetection procedures. J Neurochem 102:479-492.

Mu L, Bieri D, Slavik R, Drandarov K, Müller A, Čermak S, Weber M, Schibli R, Krämer SD, and Ametamey SM (2013) Radiolabeling and in vitro/in vivo evaluation of $\mathrm{N}$-(1-adamantyl)-8-methoxy-4-oxo-1-phenyl-1,4-dihydroquinoline-3-carboxamide as a PET probe for imaging cannabinoid type 2 receptor. J Neurochem 126:616-624.

Mu L, Slavik R, Müller A, Popaj K, Cermak S, Weber M, Schibli R, Krämer SD, and Ametamey SM (2014) Synthesis and preliminary evaluation of a 2-oxoquinoline carboxylic acid derivative for PET imaging the cannabinoid type 2 receptor. Pharmaceuticals (Basel) 7:339-352.

Müller M, Falk E, Sandbrink R, Berger U, Leier I, Jedlitschky G, Huber M, Kurz G, and Keppler D (1991) Photoaffinity labeling of leukotriene binding sites in hepatocytes and hepatoma cells. Adv Prostaglandin Thromboxane Leukot Res 21A: 395-398.

Munro S, Thomas KL, and Abu-Shaar M (1993) Molecular characterization of a peripheral receptor for cannabinoids. Nature 365:61-65.

Murad JP, Espinosa EVP, Ting HJ, and Khasawneh FT (2012) The C-terminal segment of the second extracellular loop of the thromboxane $\mathrm{A}_{2}$ receptor plays an important role in platelet aggregation. Biochem Pharmacol 83:88-96.

Murphy RC and Gijón MA (2007) Biosynthesis and metabolism of leukotrienes. Biochem J 405:379-395.

Mutoh T, Rivera R, and Chun J (2012) Insights into the pharmacological relevance of lysophospholipid receptors. Br J Pharmacol 165:829-844.

Nagata K, Tanaka K, Ogawa K, Kemmotsu K, Imai T, Yoshie O, Abe H, Tada K, Nakamura M, Sugamura K, et al. (1999) Selective expression of a novel surface molecule by human Th2 cells in vivo. $J$ Immunol 162:1278-1286.

Naka M, Mais DE, Morinelli TA, Hamanaka N, Oatis Jr JE, and Halushka PV (1992) 7-[(1R,2S,3S,5R)-6,6-dimethyl-3-(4-iodobenzenesulfonylamino)bicyclo[3.1.1]hept-2yl]-5(Z)-heptenoic acid: a novel high-affinity radiolabeled antagonist for platelet thromboxane $\mathrm{A}_{2}$ /prostaglandin $\mathrm{H}_{2}$ receptors. J Pharmacol Exp Ther 262:632-637.

Nakamoto K, Nishinaka T, Sato N, Aizawa F, Yamashita T, Mankura M, Koyama Y, Kasuya F, and Tokuyama S (2015) The activation of supraspinal GPR40/FFA1 receptor signalling regulates the descending pain control system. $\mathrm{Br}$ J Pharmacol 172:1250-1262.

Nakamura M, Honda Z, Izumi T, Sakanaka C, Mutoh H, Minami M, Bito H, Seyama Y, Matsumoto T, Noma M, et al. (1991) Molecular cloning and expression of platelet-activating factor receptor from human leukocytes. $J$ Biol Chem 266: 20400-20405.

Narumiya S, Okuma M, and Ushikubi F (1986) Binding of a radioiodinated 13-azapinane thromboxane antagonist to platelets: correlation with antiaggregatory activity in different species. $\mathrm{Br} J$ Pharmacol 88:323-331.

Nemoto K, Pilbeam CC, Bilak SR, and Raisz LG (1997) Molecular cloning and expression of a rat prostaglandin E2 receptor of the EP2 subtype. Prostaglandins 54 $713-725$

Neumeister A, Normandin MD, Pietrzak RH, Piomelli D, Zheng MQ, Gujarro-Anton A, Potenza MN, Bailey CR, Lin SF, Najafzadeh S, et al. (2013) Elevated brain cannabinoid $\mathrm{CB}_{1}$ receptor availability in post-traumatic stress disorder: a positron emission tomography study. Mol Psychiatry 18:1034-1040.

Nicosia S, Capra V, Ragnini D, Giovanazzi S, Mezzetti M, Keppler D, Müller M, and Rovati GE (1995) Receptors for cys-leukotrienes in human lung parenchyma: characterization by computer modelling and photoaffinity labelling of binding sites. Adv Prostaglandin Thromboxane Leukot Res 23:267-269.

Niehaus JL, Liu Y, Wallis KT, Egertová M, Bhartur SG, Mukhopadhyay S, Shi S, He $\mathrm{H}$, Selley DE, Howlett AC, et al. (2007) $\mathrm{CB}_{1}$ cannabinoid receptor activity is modulated by the cannabinoid receptor interacting protein CRIP 1a. Mol Pharmacol 72:1557-1566.

Niewoehner J, Bohrmann B, Collin L, Urich E, Sade H, Maier P, Rueger P, Stracke JO, Lau W, Tissot AC, et al. (2014) Increased brain penetration and potency of a therapeutic antibody using a monovalent molecular shuttle. Neuron 81:49-60.

Nøhr MK, Egerod KL, Christiansen SH, Gille A, Offermanns S, Schwartz TW, and Møller M (2015) Expression of the short chain fatty acid receptor GPR41/FFAR3 in autonomic and somatic sensory ganglia. Neuroscience 290: $126-137$.

Nussinov R and Tsai CJ (2015) The design of covalent allosteric drugs. Annu Rev Pharmacol Toxicol 55:249-267. 
Nye JS, Seltzman HH, Pitt CG, and Snyder SH (1985) High-affinity cannabinoid binding sites in brain membranes labeled with $[3 \mathrm{H}]-5$ '-trimethylammonium delta 8-tetrahydrocannabinol. J Pharmacol Exp Ther 234:784-791.

O'Callaghan G and Houston A (2015) Prostaglandin E2 and the EP receptors in malignancy: possible therapeutic targets? Br J Pharmacol 172:5239-5250.

O'Flaherty JT, Taylor JS, and Thomas MJ (1998) Receptors for the 5-oxo class of eicosanoids in neutrophils. $J$ Biol Chem 273:32535-32541.

O'Sullivan BP and Mong S (1989) Binding of radiolabeled high affinity antagonist to leukotriene $\mathrm{D}_{4}$ receptor in guinea pig lung membranes: interconversion of agonistreceptor binding affinity states. Mol Pharmacol 35:795-802.

Ogawa G, Tius MA, Zhou H, Nikas SP, Halikhedkar A, Mallipeddi S, and Makriyannis A (2015) 3'-Functionalized adamantyl cannabinoid receptor probes. J Med Chem 58: $3104-3116$

Ohta H, Sato K, Murata N, Damirin A, Malchinkhuu E, Kon J, Kimura T, Tobo M, Yamazaki Y, Watanabe T, et al. (2003) Ki16425, a subtype-selective antagonist for EDG-family lysophosphatidic acid receptors. Mol Pharmacol 64: 994-1005.

Oll M, Baumann C, Behbahani TE, von Ruecker A, Müller SC, and Ellinger J (2012) Identification of prostaglandin receptors in human ureters. BMC Urol 12:35.

Olschewski H, Simonneau G, Galiè N, Higenbottam T, Naeije R, Rubin LJ, Nikkho S, Speich R, Hoeper MM, Behr J, et al.; Aerosolized Iloprost Randomized Study Group (2002) Inhaled iloprost for severe pulmonary hypertension. $N$ Engl J Med 347:322-329.

Pacher P and Kunos G (2013) Modulating the endocannabinoid system in human health and disease: successes and failures. FEBS $J$ 280:1918-1943.

Paggiaro P and Bacci E (2011) Montelukast in asthma: a review of its efficacy and place in therapy. Ther Adv Chronic Dis 2:47-58.

Palczewski K, Kumasaka T, Hori T, Behnke CA, Motoshima H, Fox BA, Le Trong I, Teller DC, Okada T, Stenkamp RE, et al. (2000) Crystal structure of rhodopsin: a G protein-coupled receptor. Science 289:739-745.

Pałgan K and Bartuzi Z (2015) Platelet activating factor in allergies. Int $J$ Immunopathol Pharmacol 28:584-589.

Palmer SL, Thakur GA, and Makriyannis A (2002) Cannabinergic ligands. Chem Phys Lipids 121:3-19.

Pansare V, Hejazi S, Faenza W, and Prud'homme RK (2012) Review of longwavelength optical and NIR imaging materials: contrast agents, fluorophores and multifunctional nano carriers. Chem Mater 24:812-827.

Parent J-L, Gouill CL, Escher E, Rola-Pleszczynski M, and Staková J (1996) Identification of transmembrane domain residues determinant in the structure-function relationship of the human platelet-activating factor receptor by site-directed mutagenesis. J Biol Chem 271:23298-23303.

Park J, Park SY, and Kim J-H (2016) Leukotriene $\mathrm{B}_{4}$ receptor-2 contributes to chemoresistance of SK-OV-3 ovarian cancer cells through activation of signal transducer and activator of transcription-3-linked cascade. Biochim Biophys Acta 1863 236-243.

Parrill AL, Wang D, Bautista DL, Van Brocklyn JR, Lorincz Z, Fischer DJ, Baker DL, Liliom K, Spiegel S, and Tigyi G (2000) Identification of Edg1 receptor residues that recognize sphingosine 1-phosphate. J Biol Chem 275:39379-39384.

Peeters MC, van Westen GJP, Li Q, and IJzerman AP (2011) Importance of the extracellular loops in $\mathrm{G}$ protein-coupled receptors for ligand recognition and receptor activation. Trends Pharmacol Sci 32:35-42.

Pei Y, Mercier RW, Anday JK, Thakur GA, Zvonok AM, Hurst D, Reggio PH, Janero DR, and Makriyannis A (2008) Ligand-binding architecture of human CB2 cannabinoid receptor: evidence for receptor subtype-specific binding motif and modeling GPCR activation. Chem Biol 15:1207-1219.

Pertwee RG (2000) Cannabinoid receptor ligands: clinical and neuropharmacological considerations, relevant to future drug discovery and development. Expert Opin Investig Drugs 9:1553-1571.

Pertwee RG (2012) Targeting the endocannabinoid system with cannabinoid receptor agonists: pharmacological strategies and therapeutic possibilities. Philos Trans $R$ Soc Lond B Biol Sci 367:3353-3363.

Pertwee RG, Howlett AC, Abood ME, Alexander SPH, Di Marzo V, Elphick MR, Greasley PJ, Hansen HS, Kunos G, Mackie K, et al. (2010) International Union of Basic and Clinical Pharmacology. LXXIX. Cannabinoid receptors and their ligands: beyond $\mathrm{CB}_{1}$ and $\mathrm{CB}_{2}$. Pharmacol Rev 62:588-631.

Petrov RR, Ferrini ME, Jaffar Z, Thompson CM, Roberts K, and Diaz P (2011) Design and evaluation of a novel fluorescent CB2 ligand as probe for receptor visualization in immune cells. Bioorg Med Chem Lett 21:5859-5862.

Picone RP, Fournier DJ, and Makriyannis A (2002) Ligand based structural studies of the CB1 cannabinoid receptor. J Pept Res 60:348-356.

Picone RP, Khanolkar AD, Xu W, Ayotte LA, Thakur GA, Hurst DP, Abood ME, Reggio PH, Fournier DJ, and Makriyannis A (2005) (-)-7'-Isothiocyanato-11hydroxy-1', 1'-dimethylheptylhexahydrocannabinol (AM841), a high-affinity electrophilic ligand, interacts covalently with a cysteine in helix six and activates the CB1 cannabinoid receptor. Mol Pharmacol 68:1623-1635.

Pietrzak RH, Huang Y, Corsi-Travali S, Zheng MQ, Lin SF, Henry S, Potenza MN, Piomelli D, Carson RE, and Neumeister A (2014) Cannabinoid type 1 receptor availability in the amygdala mediates threat processing in trauma survivors. Neuropsychopharmacology 39:2519-2528.

Pitt CG, Seltzman HH, Setzer SR, and Williams DL (1980) The preparation of 5'iodo- ${ }^{125} \mathrm{I}-\Delta^{8}$-THC; a radioligand for the radioimmunoassay of cannabinoids. $J \mathrm{La}$ belled Comp Radiopharm 17:681-689.

Powell WS and Rokach J (2013) The eosinophil chemoattractant 5-oxo-ETE and the OXE receptor. Prog Lipid Res 52:651-665.

Prasad VP, Wagner S, Keul P, Hermann S, Levkau B, Schäfers M, and Haufe G (2014) Synthesis of fluorinated analogues of sphingosine-1-phosphate antagonists as potential radiotracers for molecular imaging using positron emission tomography. Bioorg Med Chem 22:5168-5181.

Prescott SM, Zimmerman GA, Stafforini DM, and McIntyre TM (2000) Plateletactivating factor and related lipid mediators. Annu Rev Biochem 69:419-445.
Price MR, Baillie GL, Thomas A, Stevenson LA, Easson M, Goodwin R, McLean A, McIntosh L, Goodwin G, Walker G, et al. (2005) Allosteric modulation of the cannabinoid $\mathrm{CB}_{1}$ receptor. Mol Pharmacol 68:1484-1495.

Qian Y, Hamilton M, Sidduri A, Gabriel S, Ren Y, Peng R, Kondru R, Narayanan A, Truitt T, Hamid R, et al. (2012) Discovery of highly selective and orally active lysophosphatidic acid receptor-1 antagonists with potent activity on human lung fibroblasts. J Med Chem 55:7920-7939.

Ren X-M, Cao L-Y, Zhang J, Qin W-P, Yang Y, Wan B, and Guo L-H (2016) Investigation of the binding interaction of fatty acids with human $\mathrm{G}$ protein-coupled receptor 40 using a site-specific fluorescence probe by flow cytometry. Biochemistry 55:1989-1996.

Rhodes KJ and Trimmer JS (2006) Antibodies as valuable neuroscience research tools versus reagents of mass distraction. J Neurosci 26:8017-8020.

Rinaldi-Carmona M, Pialot F, Congy C, Redon E, Barth F, Bachy A, Brelière JC, Soubrié P, and Le Fur G (1996) Characterization and distribution of binding sites for $\left[{ }^{3} \mathrm{H}\right]-\mathrm{SR}$ 141716A, a selective brain (CB1) cannabinoid receptor antagonist, in rodent brain. Life Sci 58:1239-1247.

Ring AM, Manglik A, Kruse AC, Enos MD, Weis WI, Garcia C, and Kobilka BK (2013) Adrenaline- activated structure of the $\beta 2$-adrenoceptor stabilized by an engineered nanobody. Nature 502:575-579.

Riou LM, Ruiz M, Sullivan GW, Linden J, Leong-Poi H, Lindner JR, Harris TD, Beller GA, and Glover DK (2002) Assessment of myocardial inflammation produced by experimental coronary occlusion and reperfusion with ${ }^{99 \mathrm{~m}} \mathrm{Tc}-\mathrm{RP} 517$, a new leukotriene B4 receptor antagonist that preferentially labels neutrophils in vivo. Circulation 106:592-598.

Ritter M (2000) Polyclonal and monoclonal antibodies, in Diagnostic and Therapeutic Antibodies (George AT and Urch C eds) pp 23-34, Humana Press. Inc., Totowa, NJ

Robaut C, Durand G, James C, Lave D, Sedivy P, Floch A, Mondot S, Pacot D, Cavero I, and Le Fur G (1987) PAF binding sites: characterization by $[3 \mathrm{H}] 52770 \mathrm{RP}$, a pyrrolo[1,2-c]thiazole derivative, in rabbit platelets. Biochem Pharmacol 36: $3221-3229$

Robert P, Tsui P, Laville MP, Livi GP, Sarau HM, Bril A, and Berrebi-Bertrand I (2001) EDG1 receptor stimulation leads to cardiac hypertrophy in rat neonatal myocytes. J Mol Cell Cardiol 33:1589-1606.

Rokka J, Federico C, Jurttila J, Snellman A, Haaparanta M, Rinne JO, and Solin O (2013) ${ }^{19} \mathrm{~F} /{ }^{18} \mathrm{~F}$ exchange synthesis for a novel $\left[{ }^{18} \mathrm{~F}\right] \mathrm{S}_{1} \mathrm{P}_{3}$-radiopharmaceutical. $J$ Labelled Comp Radiopharm 56:385-391.

Rosenberg AJ, Liu H, Jin H, Yue X, Riley S, Brown SJ, and Tu Z (2016) Design, synthesis and in vitro and in vivo evaluation of an ${ }^{18} \mathrm{~F}$-labeled sphingosine 1-phosphate receptor $1\left(\mathrm{~S}_{\mathrm{P}} \mathrm{P}_{1}\right)$ PET tracer. J Med Chem 59:6201-6220.

Rossin R, van Duijnhoven SM, Ten Hoeve W, Janssen HM, Kleijn LH, Hoeben FJ, Versteegen RM, and Robillard MS (2016) Triggered Drug Release from an AntibodyDrug Conjugate Using Fast "Click-to-Release" Chemistry in Mice. Bioconjug Chem. 27:1697-1706.

Rozenfeld R, Bushlin I, Gomes I, Tzavaras N, Gupta A, Neves S, Battini L, Gusella GL, Lachmann A, Ma'ayan A, et al. (2012) Receptor heteromerization expands the repertoire of cannabinoid signaling in rodent neurons. PLoS One 7:e29239.

Sabirsh A, Wetterholm A, Bristulf J, Leffler H, Haeggström JZ, and Owman C (2005) Fluorescent leukotriene $\mathrm{B}_{4}$ : potential applications. J Lipid Res 46:1339-1346.

Saccomanni G, Pascali G, Carlo SD, Panetta D, De Simone M, Bertini S, Burchielli S, Digiacomo M, Macchia M, Manera C, et al. (2015) Design, synthesis and preliminary evaluation of $\left({ }^{18}\right)$ F-labelled 1,8-naphthyridin- and quinolin-2-one-3carboxamide derivatives for PET imaging of CB2 cannabinoid receptor. Bioorg Med Chem Lett 25:2532-2535.

Sakuma Y, Shirato M, Nagaoka J, Obaishi H, Tsunoda H, Katayama S, Ono H, and Katayama K (1991) Pharmacological activities of a novel thienodiazepine derivative as a platelet-activating factor antagonist: effects on microvascular permeability, hypotension and nephrosis. Arzneimittelforschung 41:1255-1259.

Salom D, Padayatti PS, and Palczewski K (2013) Crystallization of G protein-coupled receptors. Methods Cell Biol 117:451-468.

Santini G, Mores N, Malerba M, Mondino C, Macis G, and Montuschi P (2016) In vestigational prostaglandin $\mathrm{D}_{2}$ receptor antagonists for airway inflammation. $E x$ pert Opin Investig Drugs 25:639-652.

Santus P and Radovanovic D (2016) Prostaglandin D2 receptor antagonists in early development as potential therapeutic options for asthma. Expert Opin Investig Drugs 25:1083-1092.

Savonenko AV, Melnikova T, Wang Y, Ravert H, Gao Y, Koppel J, Lee D, Pletnikova O, Cho E, Sayyida N, et al. (2015) Cannabinoid CB2 receptors in a mouse model of $\mathrm{A} \beta$ amyloidosis: immunohistochemical analysis and suitability as a PET biomarker of neuroinflammation. PLoS One 10:e0129618.

Schain F, Tryselius Y, Sjöberg J, Porwit A, Backman L, Malec M, Xu D, Vockerodt M, Baumforth KR, Wei W, et al. (2008) Evidence for a pathophysiological role of cysteinyl leukotrienes in classical Hodgkin lymphoma. Int $J$ Cancer 123: $2285-2293$

Scheigetz J, Berthelette C, Li C, and Zamboni RJ (2004) Base-catalyzed deuterium and tritium labeling of aryl methyl sulfones. J Labelled Comp Radiopharm 47 881-889.

Schou M, Varnäs K, Jucaite A, Gulyás B, Halldin C, and Farde L (2013) Radiolabeling of the cannabinoid receptor agonist AZD1940 with carbon-11 and PET microdosing in non-human primate. Nucl Med Biol 40:410-414.

Schroeder Jr HW and Cavacini L (2010) Structure and function of immunoglobulins. J Allergy Clin Immunol 125(2, Suppl 2):S41-S52.

Sergeev E, Hansen AH, Pandey SK, MacKenzie AE, Hudson BD, Ulven T, and Milligan G (2016) Non-equivalence of key positively charged residues of the free fatty acid 2 receptor in the recognition and function of agonist versus antagonist ligands. $J$ Biol Chem 291:303-317.

Sexton M, Woodruff G, Horne EA, Lin YH, Muccioli GG, Bai M, Stern E, Bornhop DJ, and Stella N (2011) NIR-mbc94, a fluorescent ligand that binds to endogenous CB ${ }_{2}$ ) receptors and is amenable to high-throughput screening. Chem Biol 18:563-568. 
Shaikh RS, Schilson SS, Wagner S, Hermann S, Keul P, Levkau B, Schäfers M, and Haufe G (2015) Synthesis and evaluation of fluorinated fingolimod (FTY720) analogues for sphingosine-1-phosphate receptor molecular imaging by positron emission tomography. J Med Chem 58:3471-3484.

Shao Z, Yin J, Chapman K, Grzemska M, Clark L, Wang J, and Rosenbaum DM (2016) High-resolution crystal structure of the human CB1 cannabinoid receptor. Nature 540:602-606.

Sharif NA, Davis TL, and Williams GW (1999) [3H]AL-5848 ([3H]9ß-(+)-fluprostenol): carboxylic acid of travoprost (AL-6221), a novel FP prostaglandin to study the pharmacology and autoradiographic localization of the FP receptor. J Pharm Pharmacol 51:685-694.

Sharif NA, Williams GW, and Davis TL (2000) Pharmacology and autoradiography of human DP prostanoid receptors using $\left[\left({ }^{3)} \mathrm{H}\right]-\mathrm{BWA} 868 \mathrm{C}\right.$, a DP receptor-selective antagonist radioligand. $\mathrm{Br} J$ Pharmacol 131:1025-1038.

Shelnut EL, Nikas SP, Finnegan DF, Chiang N, Serhan CN, and Makriyannis A (2015) Design and synthesis of novel prostaglandin $\mathrm{E}_{2}$ ethanolamide and glycerol ester probes for the putative prostamide receptor(s). Tetrahedron Lett 56: $1411-1415$.

Shirasaki H, Kanaizumi E, Seki N, Kikuchi M, Watanabe K, Konno N, and Himi T (2006) Distribution of specific binding sites for cysteinyl leukotriene 1 receptor antagonist in human nasal mucosa. Acta Otolaryngol 126:948-951.

Sic H, Kraus H, Madl J, Flittner K-A, von Münchow AL, Pieper K, Rizzi M, Kienzler A-K, Ayata K, Rauer S, et al. (2014) Sphingosine-1-phosphate receptors control B-cell migration through signaling components associated with primary immunodeficiencies, chronic lymphocytic leukemia, and multiple sclerosis. J Allergy Clin Immunol 134:420-428.

Singh A, Chaudhary S, Agarwal A, and Verma AS (2014) Antibodies: monoclonal and polyclonal, in Anim Biotechnol (Singh ASV ed) pp 265-287, Academic Press, San Diego, CA.

Singh J, Petter RC, Baillie TA, and Whitty A (2011) The resurgence of covalent drugs. Nat Rev Drug Discov 10:307-317.

Singh P, Singh IN, Mondal SC, Singh L, and Garg VK (2013a) Platelet-activating factor (PAF): antagonists of natural origin. Fitoterapia 84:180-201.

Singh RK, Tandon R, Dastidar SG, and Ray A (2013b) A review on leukotrienes and their receptors with reference to asthma. J Asthma 50:922-931.

Slavik R, Grether U, Müller Herde A, Gobbi L, Fingerle J, Ullmer C, Krämer SD, Schibli R, Mu L, and Ametamey SM (2015a) Discovery of a high affinity and selective pyridine analog as a potential positron emission tomography imaging agent for cannabinoid type 2 receptor. J Med Chem 58:4266-4277.

Slavik R, Herde AM, Bieri D, Weber M, Schibli R, Krämer SD, Ametamey SM, and $\mathrm{Mu} \mathrm{L}$ (2015b) Synthesis, radiolabeling and evaluation of novel 4-oxo-quinoline derivatives as PET tracers for imaging cannabinoid type 2 receptor. Eur $J$ Med Chem 92:554-564.

Slavik R, Müller Herde A, Haider A, Krämer SD, Weber M, Schibli R, Ametamey SM, and $\mathrm{Mu} \mathrm{L}$ (2016) Discovery of a fluorinated 4-oxo-quinoline derivative as a potential positron emission tomography radiotracer for imaging cannabinoid receptor type 2. J Neurochem 138:874-886.

Slipetz DM, O'Neill GP, Favreau L, Dufresne C, Gallant M, Gareau Y, Guay D, Labelle M, and Metters KM (1995) Activation of the human peripheral cannabinoid receptor results in inhibition of adenylyl cyclase. Mol Pharmacol 48: 352-361.

Slipetz DM, Scoggan KA, Nicholson DW, and Metters KM (1993) Photoaffinity labelling and radiation inactivation of the leukotriene $\mathrm{B}_{4}$ receptor in human myeloid cells. Eur J Pharmacol 244:161-173.

Smith WL, Urade Y, and Jakobsson PJ (2011) Enzymes of the cyclooxygenase pathways of prostanoid biosynthesis. Chem Rev 111:5821-5865.

Smoum R, Baraghithy S, Chourasia M, Breuer A, Mussai N, Attar-Namdar M, Kogan NM, Raphael B, Bolognini D, Cascio MG, et al. (2015) CB2 cannabinoid receptor agonist enantiomers HU-433 and HU-308: an inverse relationship between binding affinity and biological potency. Proc Natl Acad Sci USA 112 8774-8779.

Song ZH and Bonner TI (1996) A lysine residue of the cannabinoid receptor is critical for receptor recognition by several agonists but not WIN55212-2. Mol Pharmacol 49:891-896.

Souza DG, Fagundes CT, Sousa LP, Amaral FA, Souza RS, Souza AL, Kroon EG, Sachs D, Cunha FQ, Bukin E, et al. (2009) Essential role of platelet-activating factor receptor in the pathogenesis of Dengue virus infection. Proc Natl Acad Sci USA 106:14138-14143.

Sridharan R, Zuber J, Connelly SM, Mathew E, and Dumont ME (2014) Fluorescent approaches for understanding interactions of ligands with $\mathrm{G}$ protein coupled receptors. Biochim Biophys Acta 1838:15-33.

Srivastava A, Yano J, Hirozane Y, Kefala G, Gruswitz F, Snell G, Lane W, Ivetac A, Aertgeerts K, Nguyen J, et al. (2014) High-resolution structure of the human GPR40 receptor bound to allosteric agonist TAK-875. Nature 513:124-127.

Stalder AK, Lott D, Strasser DS, Cruz HG, Krause A, Groenen PM, and Dingemanse $\mathrm{J}$ (2017) Biomarker-guided clinical development of the first-in-class anti-inflammatory FPR2/ALX agonist ACT-389949. Br J Clin Pharmacol 83:476-486.

Staus DP, Strachan RT, Manglik A, Pani B, Kahsai AW, Kim TH, Wingler LM, Ahn S, Chatterjee A, Masoudi A, Kruse AC, Pardon E, Steyaert J, Weis WI, Prosser RS, Kobilka BK, Costa T, and Lefkowitz RJ (2016) Allosteric nanobodies reveal the dynamic range and diverse mechanisms of G-protein-coupled receptor activation. Nature 535:448-452.

Stoddard NC and Chun J (2015) Promising pharmacological directions in the world of lysophosphatidic acid signaling. Biomol Ther (Seoul) 23:1-11.

Stoddart LA, Kilpatrick LE, Briddon SJ, and Hill SJ (2015) Probing the pharmacology of G protein-coupled receptors with fluorescent ligands. Neuropharmacology 98:48-57.

Stoddart LA, Smith NJ, and Milligan G (2008) International Union of Pharmacology. LXXI. Free fatty acid receptors FFA1, -2, and -3: pharmacology and pathophysiological functions. Pharmacol Rev 60:405-417.
Stoddart LA, White CW, Nguyen K, Hill SJ, and Pfleger KD (2016) Fluorescence- and bioluminescence-based approaches to study GPCR ligand binding. Br J Pharmacol 173:3028-3037.

Strømgaard K, Saito DR, Shindou H, Ishii S, Shimizu T, and Nakanishi K (2002) Ginkgolide derivatives for photolabeling studies: preparation and pharmacological evaluation. J Med Chem 45:4038-4046.

Sturino CF, O’Neill G, Lachance N, Boyd M, Berthelette C, Labelle M, Li L, Roy B Scheigetz J, Tsou N, et al. (2007) Discovery of a potent and selective prostaglandin $\mathrm{D}_{2}$ receptor antagonist, [(3R)-4-(4-chloro-benzyl)-7-fluoro-5-(methylsulfonyl)-1,2,3,4tetrahydrocyclopenta[b]indol-3-yl]-acetic acid (MK-0524). J Med Chem 50: 794-806.

Sugimoto H, Shichijo M, Okano M, and Bacon KB (2005) CRTH2-specific binding characteristics of $\left[{ }^{3} \mathrm{H}\right]$ ramatroban and its effects on $\mathrm{PGD}_{2^{-}}, 15$-deoxy- $\Delta^{12,14}-\mathrm{PGJ}_{2^{-}}$ and indomethacin-induced agonist responses. Eur J Pharmacol 524:30-37.

Sugiura T, Kondo S, Sukagawa A, Nakane S, Shinoda A, Itoh K, Yamashita A and Waku K (1995) 2-Arachidonoylglycerol: a possible endogenous cannabinoid receptor ligand in brain. Biochem Biophys Res Commun 215:89-97.

Sumranjit J and Chung SJ (2013) Recent advances in target characterization and identification by photoaffinity probes. Molecules 18:10425-10451.

Suter TM, Chesterfield AK, Bao C, Schaus JM, Krushinski JH, Statnick MA and Felder CC (2010) Pharmacological characterization of the cannabinoid $\mathrm{CB}_{1}$ receptor PET ligand ortholog, $\left[{ }^{3} \mathrm{H}\right]$ MePPEP. Eur J Pharmacol 649:44-50.

Suzuki M, Koyano H, Noyori R, Hashimoto H, Negishi M, Ichikawa A, and Ito S (1992) An azido-functionalized isocarbacyclin analogue acting as an efficient photoaffinity probe for a prostacyclin receptor. Tetrahedron 48:2635-2658

Sykes DA, Bradley ME, Riddy DM, Willard E, Reilly J, Miah A, Bauer C, Watson SJ, Sandham DA, Dubois G, et al. (2016) Fevipiprant (QAW039), a slowly dissociating CRTh2 antagonist with the potential for improved clinical efficacy. Mol Pharmacol 89:593-605.

Szymanski DW, Papanastasiou M, Melchior K, Zvonok N, Mercier RW, Janero DR, Thakur GA, Cha S, Wu B, Karger B, et al. (2011) Mass spectrometry-based proteomics of human cannabinoid receptor 2: covalent cysteine 6.47(257)-ligand interaction affording megagonist receptor activation. $J$ Proteome Res 10 $4789-4798$

Takeda H, Ogasawara T, Ozawa T, Muraguchi A, Jih P-J, Morishita R, Uchigashima M, Watanabe M, Fujimoto T, Iwasaki T, et al. (2015) Production of monoclonal antibodies against GPCR using cell-free synthesized GPCR antigen and biotinylated liposome-based interaction assay. Sci Rep 5:11333.

Talmont F and Moulédous L (2014) Evaluation of commercial antibodies against human sphingosine-1-phosphate receptor 1. Naunyn Schmiedebergs Arch Pharmacol 387:427-431.

Tang X, Benesch MG, and Brindley DN (2015) Lipid phosphate phosphatases and their roles in mammalian physiology and pathology. J Lipid Res 56:2048-2060.

Terai K, Soga T, Takahashi M, Kamohara M, Ohno K, Yatsugi S, Okada M, and Yamaguchi T (2003) Edg-8 receptors are preferentially expressed in oligodendrocyte lineage cells of the rat CNS. Neuroscience 116:1053-1062.

Teutsch C-A, Panse M, Grundmann M, Kaiser G, Kostenis E, Häring H-U, and Ullrich S (2014) Detection of free fatty acid receptor 1 expression: the critica role of negative and positive controls. Diabetologia 57:776-780.

Thakur GA, Nikas SP, Li C, and Makriyannis A (2005) Structural requirements for cannabinoid receptor probes, in Cannabinoids (Pertwee RG ed) pp 209-246, Springer, Berlin Heidelberg.

Theis JGW, Dellweg H, Perzborn E, and Gross R (1992) Binding characteristics of the new thromboxane $\mathrm{A}_{2}$ /prostaglandin $\mathrm{H}_{2}$ receptor antagonist $\left[{ }^{3} \mathrm{H}\right] \mathrm{BAY} \mathrm{U} 3405$ to washed human platelets and platelet membranes. Biochem Pharmacol 44: 495-503.

Theron AJ, Steel HC, Tintinger GR, Gravett CM, Anderson R, and Feldman C (2014) Cysteinyl leukotriene receptor-1 antagonists as modulators of innate immune cell function. J Immunol Res 2014:608930.

Thomson FJ, Perkins L, Ahern D, and Clark M (1994) Identification and characterization of a lysophosphatidic acid receptor. Mol Pharmacol 45:718-723.

Tian X, Guo J, Yao F, Yang DP, and Makriyannis A (2005) The conformation, location, and dynamic properties of the endocannabinoid ligand anandamide in a membrane bilayer. J Biol Chem 280:29788-29795.

Tikhonova IG and Poerio E (2015) Free fatty acid receptors: structural models and elucidation of ligand binding interactions. BMC Struct Biol 15:16.

Toda A, Yokomizo T, Masuda K, Nakao A, Izumi T, and Shimizu T (1999) Cloning and characterization of rat leukotriene B4 receptor. Biochem. Biophys. Res. Commun., 262:806-812.

Tomasch M, Schwed JS, Kuczka K, Meyer Dos Santos S, Harder S, Nüsing RM, Paulke A, and Stark H (2012) Fluorescent human EP3 receptor antagonists. ACS Med Chem Lett 3:774-779.

True TA and Mais DE (1994) Localization of $\left[{ }^{125} \mathrm{I}\right] \mathrm{SAP}-\mathrm{N}_{3}$ binding in the human platelet thromboxane $\mathrm{A}_{2}$ /prostaglandin $\mathrm{H}_{2}$ receptor by proteolytic cleavage analysis. Eur J Pharmacol 266:51-55.

Tsunoda H, Sakuma Y, Harada K, Muramoto K, Katayama S, Horie T, Shimomura N, Clark R, Miyazawa S, Okano K, et al. (1990) Pharmacological activities of a novel thienodiazepine derivative as a platelet-activating factor antagonist. Arzneimittelforschung 40:1201-1205.

Ukena D, Dent G, Birke FW, Robaut C, Sybrecht GW, and Barnes PJ (1988) Radioligand binding of antagonists of platelet-activating factor to intact human platelets. FEBS Lett 228:285-289.

Ulven T, Gallen MJ, Nielsen MC, Merten N, Schmidt C, Mohr K, Tränkle C, and Kostenis E (2007) Synthesis and in vitro evaluation of a selective antagonist and the corresponding radioligand for the prostaglandin D2 receptor CRTH2. Bioorg Med Chem Lett 17:5924-5927.

Ushikubi F, Nakajima M, Yamamoto M, Ohtsu K, Kimura Y, Okuma M, Uchino H, Fujiwara M, and Narumiya S (1989) [3H]S-145 and [125I]I-S-145-OH: new radioligands for platelet thromboxane $\mathrm{A} 2$ receptor with low nonspecific binding and high binding affinity for various receptor preparations. Eicosanoids 2:21-27. 
Van Brocklyn JR, Gräler MH, Bernhardt G, Hobson JP, Lipp M, and Spiegel S (2000) Sphingosine-1-phosphate is a ligand for the G protein-coupled receptor EDG-6. Blood 95:2624-2629.

van Eerd JE, Oyen WJ, Harris TD, Rennen HJ, Edwards DS, Liu S, Ellars CE, Corstens FH, and Boerman OC (2003) A bivalent leukotriene $\left.\mathrm{B}_{4}\right)$ antagonist for scintigraphic imaging of infectious foci. J Nucl Med 44:1087-1091.

Van Mensel K, Claerhout F, Debois P, Keirse MJNC, and Hanssens M (2009) A randomized controlled trial of misoprostol and sulprostone to end pregnancy after fetal death. Obstet Gynecol Int 2009:496320.

Vandewerf F, Santopinto J, Cordero FA, Fainstein D, Corinaldesi A, Zavatti D, Luppi O, Iparraguirre HP, Hirschson A, Piombo A, et al. (1994) Randomized trial of ridogrel, a combined thromboxane $\mathrm{A}_{2}$ synthase inhibitor and thromboxane $\mathrm{A}_{2} /$ prostaglandin endoperoxide receptor antagonist, versus aspirin as adjunct to thrombolysis in patients with acute myocardial infarction: The Ridogrel Versus Aspirin Patency Trial (RAPT). Circulation 89:588-595.

Vasilevsky NA, Brush MH, Paddock H, Ponting L, Tripathy SJ, Larocca GM, and Haendel MA (2013) On the reproducibility of science: unique identification of research resources in the biomedical literature. PeerJ 1:e148.

Vaughan RA, Parnas ML, Gaffaney JD, Lowe MJ, Wirtz S, Pham A, Reed B, Dutta SM, Murray KK, and Justice JB (2005) Affinity labeling the dopamine transporter ligand binding site. J Neurosci Methods 143:33-40.

Vemuri VK and Makriyannis A (2015) Medicinal chemistry of cannabinoids. Clin Pharmacol Ther 97:553-558.

Vernall AJ, Hill SJ, and Kellam B (2014) The evolving small-molecule fluorescentconjugate toolbox for class A GPCRs. Br J Pharmacol 171:1073-1084.

Vodovozova EL (2007) Photoaffinity labeling and its application in structural biology. Biochemistry (Mosc) 72:1-20.

Volk DW, Eggan SM, Horti AG, Wong DF, and Lewis DA (2014) Reciprocal alterations in cortical cannabinoid receptor 1 binding relative to protein immunoreactivity and transcript levels in schizophrenia. Schizophr Res 159:124-129.

Weichert D and Gmeiner P (2015) Covalent molecular probes for class A G proteincoupled receptors: advances and applications. ACS Chem Biol 10:1376-1386.

Whittle BJ, Silverstein AM, Mottola DM, and Clapp LH (2012) Binding and activity of the prostacyclin receptor (IP) agonists, treprostinil and iloprost, at human prostanoid receptors: treprostinil is a potent DP1 and EP2 agonist. Biochem Pharmacol 84:68-75.

Wong R and Dolman SJ (2007) Isothiocyanates from tosyl chloride mediated decomposition of in situ generated dithiocarbamic acid salts. $J$ Org Chem 72 3969-3971.

Woodward DF, Jones RL, and Narumiya S (2011) International Union of Basic and Clinical Pharmacology. LXXXIII: classification of prostanoid receptors, updating 15 years of progress. Pharmacol Rev 63:471-538.

Wu Z, Shao P, Zhang S, and Bai M (2014a) Targeted zwitterionic near infrared fluorescent probe for improved imaging of type 2 cannabinoid receptors. J Biomed Opt 19:36006.

Wu Z, Shao P, Zhang S, Ling X, and Bai M (2014b) Molecular imaging of human tumor cells that naturally overexpress type 2 cannabinoid receptors using a quinolone-based near-infrared fluorescent probe. J Biomed Opt 19:76016.
Xu Y (2016) Recent progress on bile acid receptor modulators for treatment of metabolic diseases. J Med Chem 59:6553-6579.

Yamada K, Rice KC, Flippen-Anderson JL, Eissenstat MA, Ward SJ, Johnson MR, and Howlett AC (1996) (Aminoalkyl)indole isothiocyanates as potential electrophilic affinity ligands for the brain cannabinoid receptor. J Med Chem 39: 1967-1974.

Yamamoto T, Hasegawa H, Hakogi T, and Katsumura S (2008) Syntheses of fluorescence-labeled sphingosine 1-phosphate methylene and sulfur analogues as possible visible ligands to the receptor. Chem Lett 37:188-189.

Yang Y, Miller KJ, Zhu Y, Hong Y, Tian Y, Murugesan N, Gu Z, O’Tanyi E, Keim WJ, Rohrbach KW, et al. (2011) Characterization of a novel and selective CB1 antagonist as a radioligand for receptor occupancy studies. Bioorg Med Chem Lett 21: $6856-6860$

Yates AS, Doughty SW, Kendall DA, and Kellam B (2005) Chemical modification of the naphthoyl 3-position of JWH-015: in search of a fluorescent probe to the cannabinoid $\mathrm{CB}_{2}$ receptor. Bioorg Med Chem Lett 15:3758-3762.

Yokomizo T, Izumi T, Chang K, Takuwa Y, and Shimizu T (1997) A G-protein-coupled receptor for leukotriene B4 that mediates chemotaxis. Nature 387:620-624.

Yrjölä S, Sarparanta M, Airaksinen AJ, Hytti M, Kauppinen A, Pasonen-Seppänen S, Adinolfi B, Nieri P, Manera C, Keinänen O, et al. (2015) Synthesis, in vitro and in vivo evaluation of 1,3,5-triazines as cannabinoid CB2 receptor agonists. Eur $J$ Pharm Sci 67:85-96.

Yue X, Jin H, Liu H, Rosenberg AJ, Klein RS, and Tu Z (2015) A potent and selective C-11 labeled PET tracer for imaging sphingosine-1-phosphate receptor 2 in the CNS demonstrates sexually dimorphic expression. Org Biomol Chem 13: $7928-7939$

Yung YC, Stoddard NC, Mirendil H, and Chun J (2015) Lysophosphatidic acid signaling in the nervous system. Neuron 85:669-682.

Zhang S, Jia N, Shao P, Tong Q, Xie XQ, and Bai M (2014) Target-selective phototherapy using a ligand-based photosensitizer for type 2 cannabinoid receptor. Chem Biol 21:338-344.

Zhang S, Shao P, and Bai M (2013) In vivo type 2 cannabinoid receptor-targeted tumor optical imaging using a near infrared fluorescent probe. Bioconjug Chem 24: 1907-1916.

Zhang S, Shao P, Ling X, Yang L, Hou W, Thorne SH, Beaino W, Anderson CJ, Ding $\mathrm{Y}$, and Bai $\mathrm{M}$ (2015) In vivo inflammation imaging using a $\mathrm{CB}_{2} \mathrm{R}$-targeted near infrared fluorescent probe. Am J Nucl Med Mol Imaging 5:246-258.

Zhuang Q, Bastien Y, and Mazer BD (2000) Activation via multiple signaling pathways induces down-regulation of platelet-activating factor receptors on human B lymphocytes. J Immunol 165:2423-2431.

Zuo S, Ge H, Li Q, Zhang X, Hu R, Hu S, Liu X, Zhang JH, Chen Y, and Feng H (2017) Artesunate protected blood-brain barrier via sphingosine 1 phosphate receptor 1/phosphatidylinositol 3 kinase pathway after subarachnoid hemorrhage in rats. Mol Neurobiol 54:1213-1228.

Zvonok N, Pandarinathan L, Williams J, Johnston M, Karageorgos I, Janero DR, Krishnan SC, and Makriyannis A (2008) Covalent inhibitors of human monoacylglycerol lipase: ligand-assisted characterization of the catalytic site by mass spectrometry and mutational analysis. Chem Biol 15:854-862. 